\title{
Efficient Dimerization Disruption of Leishmania infantum Trypanothione Reductase by Triazole-phenyl-thiazoles
}

\author{
Alejandro Revuelto," Héctor de Lucio," Juan Carlos García-Soriano, Pedro A. Sánchez-Murcia, \\ Federico Gago, Antonio Jiménez-Ruiz,* María-José Camarasa, and Sonsoles Velázquez*
}

Cite This: J. Med. Chem. 2021, 64, 6137-6160

Read Online

\section{ACCESS |}

Џlll Metrics \& More

Article Recommendations

Supporting Information

ABSTRACT: Inhibition of Leishmania infantum trypanothione disulfide reductase ( $L i$ TryR) by disruption of its homodimeric interface has proved to be an alternative and unexploited strategy in the search for novel antileishmanial agents. Proof of concept was first obtained by peptides and peptidomimetics. Building on previously reported dimerization disruptors containing an imidazole-phenyl-thiazole scaffold, we now report a new 1,2,3triazole-based chemotype that yields noncompetitive, slow-binding inhibitors of $L i$ TryR. Several compounds bearing (poly)aromatic substituents dramatically improve the ability to disrupt LiTryR dimerization relative to reference imidazoles. Molecular modeling
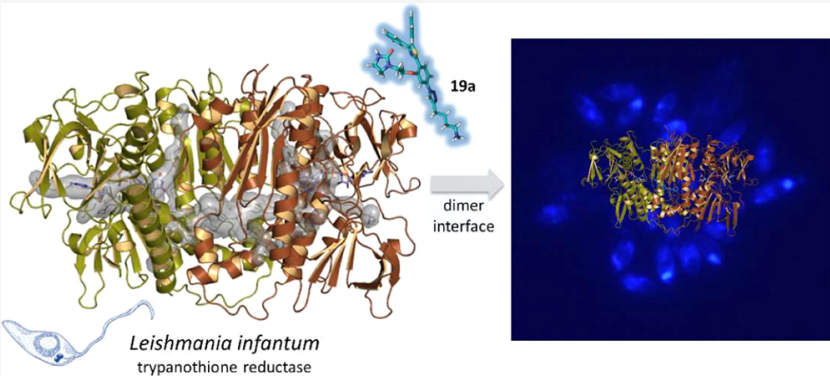
studies identified an almost unexplored hydrophobic region at the interfacial domain as the putative binding site for these compounds. A subsequent structure-based design led to a symmetrical triazole analogue that displayed even more potent inhibitory activity over LiTryR and enhanced leishmanicidal activity. Remarkably, several of these novel triazole-bearing compounds were able to kill both extracellular and intracellular parasites in cell cultures.

\section{INTRODUCTION}

Leishmaniasis is an infectious disease caused by intracellular protozoan parasites from more than 20 Leishmania species and transmitted to humans through the bite of infected female phlebotomine sandflies. According to the World Health Organization (WHO), leishmaniasis is one of the major neglected tropical diseases that affects 12 million people in 98 countries, being especially prevalent in tropical and subtropical areas. ${ }^{1}$ Visceral leishmaniasis (VL), also known as Kala-azar, is the most severe form of the disease with more than 60000 human deaths annually. VL is caused by Leishmania donovani and Leishmania infantum parasites worldwide, including Mediterranean countries. ${ }^{2}$ No effective vaccine for humans has so far been developed, and leishmaniasis control mainly relies on chemotherapy. ${ }^{3,4}$ However, currently available treatments are inadequate because of high costs, toxicity, drug resistance, and the need for parenteral administration. ${ }^{5,6}$ Therefore, there is an urgent need to find new effective innovative drugs against this disease.

Herein, we report a target-based approach for the discovery of novel agents against $L$. infantum parasites targeting a protein that is essential for parasite survival and exclusive for these parasites. ${ }^{7,8}$ We have focused on trypanothione (Try) disulfide reductase (TryR) because it is one of the few genetically and chemically validated drug targets, and validation is one important criterion in target assessment. ${ }^{9-11}$ Among other highly relevant functions, this enzyme is essential for antioxidant defense in trypanosomatids. The Try/TryR couple in these parasites substitutes for the glutathione/glutathionedisulfide reductase (GR) pair characteristic of most eukaryotic organisms. Accordingly, the absence of TryR in mammalian cells, the significant differences between TryR and human GR (hGR) (the active sites of the two enzymes have opposite net charges and different volumes), and its crucial role for parasite survival make TryR an attractive target for new chemotherapeutics. ${ }^{12-15}$ Since this enzyme was identified, many potent and selective competitive polycationic TryR inhibitors (which mimic the positively charged Try in the active site) have been described. However, there are scarce reports of potent TryR-inhibiting compounds with adequate antiparasitic activity. ${ }^{16,17}$ This is so because it has been shown that survival of the parasites is only affected when TryR activity is reduced by more than $90 \%$, probably as a consequence of the high intracellular concentrations of its natural substrate (Try) in the cell. ${ }^{18}$ This implies that, to be effective against the parasites, competitive inhibitors must have very high binding affinities so as to give rise to inhibition constants in the low nanomolar

Received: February 3, 2021

Published: May 4, 2021 


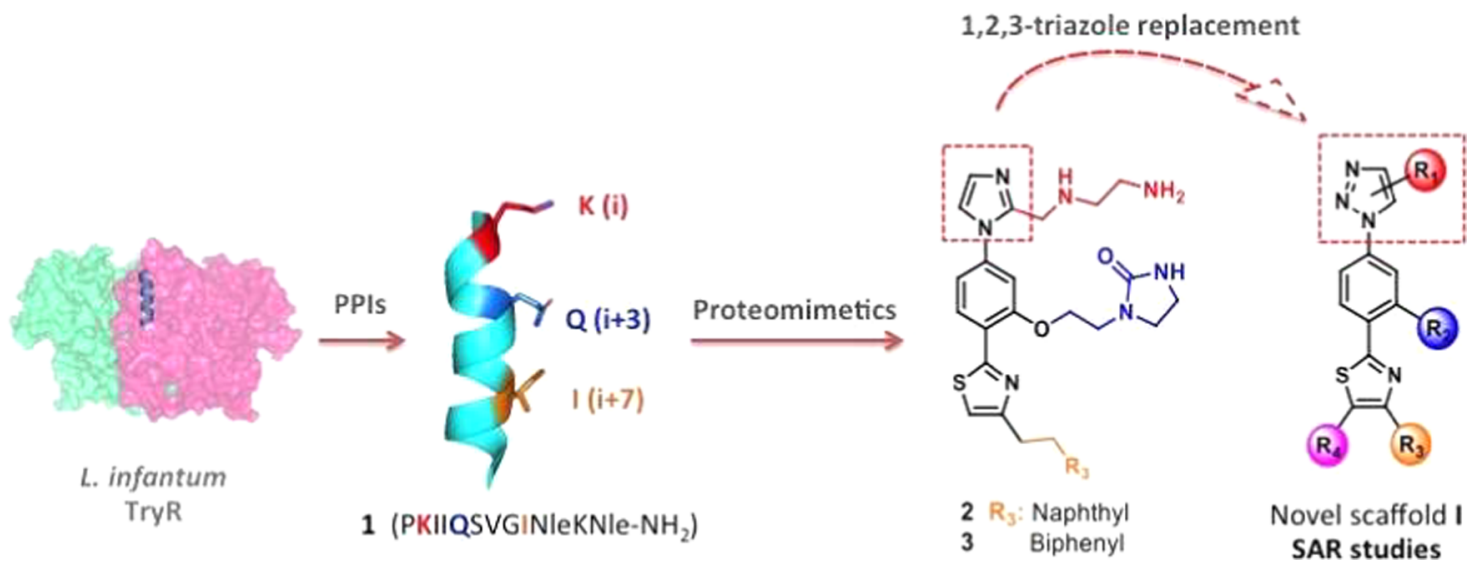

Figure 1. From a peptide dimerization disruptor of $L i \operatorname{TryR}(\mathbf{1})$ and in-house imidazoles 2 and 3 to the newly designed triazole-phenyl-thiazole scaffold I.

range. Nonetheless, one of the most potent (submicromolar) competitive inhibitors of Trypanosoma brucei ( $T b$ TryR) described to date is almost inactive against $L$. donovani. ${ }^{19}$ This limitation, together with the need for very high affinities imposed by the high intracellular concentrations of both the natural substrate (between 3 and $50 \mu \mathrm{M}$ under steady-state conditions and up to $150 \mu \mathrm{M}$ under oxidative stress) and TryR itself $(0.5-1.3 \mu \mathrm{M})$, make noncompetitive and/or irreversible inhibitors emerge as more attractive alternatives for targeting this enzyme. ${ }^{20 a, b, 21}$

The crystal structure of TryR from L. infantum (LiTryR) was first solved by Baiocco et al. ${ }^{22}$ and is very similar to that of other trypanosomatids. ${ }^{13,14,16,23,24}$ This enzyme is a twofold symmetrical homodimer that contains two active sites and two reduced nicotinamide adenine dinucleotide phosphate $(\mathrm{NADPH})$ - and flavin adenine dinucleotide (FAD)-binding domains separated by a large and well-characterized interface. $^{25}$ Each Try binding site is located in a large solventexposed cavity at the interface between the two monomers. Several X-ray crystal structures of TryR in complex with a variety of competitive reversible inhibitors have shown that the large pocket allows not only several binding modes for smallmolecule inhibitors but also the simultaneous binding of more than one inhibitor molecule. ${ }^{23}$ Such unpredictable binding modes, due to the large size of the active site, make the rational design of competitive, high-affinity inhibitors of TryR a very challenging task.

Bearing in mind the homodimeric nature of this enzyme, back in 2013 we devised an alternative inhibition strategy that aims to disrupt the protein-protein interactions responsible for $L i T r y R$ homodimerization. ${ }^{25}$ Initially, by means of a combination of molecular modeling and site-directed mutagenesis studies, we identified and validated E436-an amino acid located at an interfacial $\alpha$-helix spanning from P435 to M447-as a hotspot for dimer stabilization and assessed its importance for the catalytic activity of the enzyme. As a "proof of concept" of this novel approach, we designed and tested a small library of linear peptides that represent rational variations of this $\alpha$-helix. From these studies, the 13-mer-modified peptide sequence PKIIQSVGIS-Nle-K-Nle (1) emerged as a potent enzyme dimerization disruptor that also behaves as a strong inhibitor (in the submicromolar range) of the oxidoreductase activity of $L i \operatorname{TryR}^{25} \mathrm{Next}$, a variety of helixstabilized cyclic peptides ${ }^{26,27}$ and $\alpha, \beta^{3}$-peptide foldamers ${ }^{28}$ were successfully explored in our search to find peptidomi- metics with increased proteolytic stability. However, conjugation with cell-penetrating peptides was always required to facilitate the cellular uptake of these peptide- or peptidomimetic-based LiTryR dimerization disruptors and to kill the parasites in cell culture. ${ }^{28,29}$ Thus, the design of small molecules with druglike properties better than those of the prototype peptide or the previous peptidomimetics appeared as a desirable goal.

In this regard, we recently disclosed the results of our first steps toward nonpeptide disruptors of LiTryR dimerization with promising leishmanicidal activity by an $\alpha$-helical mimetic approach. ${ }^{30}$ Among the reported proteomimetic scaffolds, ${ }^{31-33}$ the pyrrolopyrimidine ${ }^{34}$ and the 5-6-5 imidazole-phenylthiazole $^{35}$ cores were selected to dictate the spatial orientations of the side chains of three key residues (K2, Q5, and I9) in the linear peptide prototype 1. Imidazole-based compounds $\mathbf{2}$ and 3 (Figure 1), bearing a naphthalene or a biphenyl polyaromatic $\mathrm{R}_{3}$ substituent to mimic the hydrophobic isoleucine residue, emerged as potent inhibitors of the $L i$ TryR oxidoreductase activity, while pyrrolopyrimidines were shown to be much less active. Although these small molecules displayed a moderate capacity to disrupt the $L i T r y R$ dimer, this effect was much less pronounced than that observed for the previous peptide-based inhibitors. Remarkably, the imidazole-based compounds were cell-permeable and showed significant leishmanicidal activity against both amastigote and promastigote forms of Leishmania parasites. However, these molecules displayed a cytotoxic activity similar to that observed for their peptidic and peptidomimetic predecessors and exhibited low selectivity indexes (SIs).

1,2,3-Triazole-containing compounds have been widely investigated because they are considered privileged scaffolds in different areas of medicinal chemistry, ${ }^{36-38}$ including several examples in the antileishmanial field. ${ }^{39}$ Interest in this molecular architecture has also been fueled by its expedient synthesis through "click chemistry" ${ }^{40}$ In this scenario, we decided to apply the bioisosteric replacement of imidazole by 1,2,3-triazole in our recently described imidazole-phenylthiazoles. ${ }^{30}$ We herein report the synthesis and structureactivity relationship (SAR) studies of novel 1,2,3-triazolephenyl-thiazole compounds of general formulae I (Figure 1) to demonstrate the potential of this novel chemotype for LiTryR dimerization disruption and leishmanicidal activity against $L$. infantum parasites. A whole set of 26 triazole-based compounds modified at four different positions in the new scaffold $\left(\mathrm{R}_{1}-\mathrm{R}_{4}\right.$ 
Scheme 1. Synthesis of the First Series of 1,4-Disubstituted 1,2,3-Triazole Compounds 12a-c ${ }^{a}$
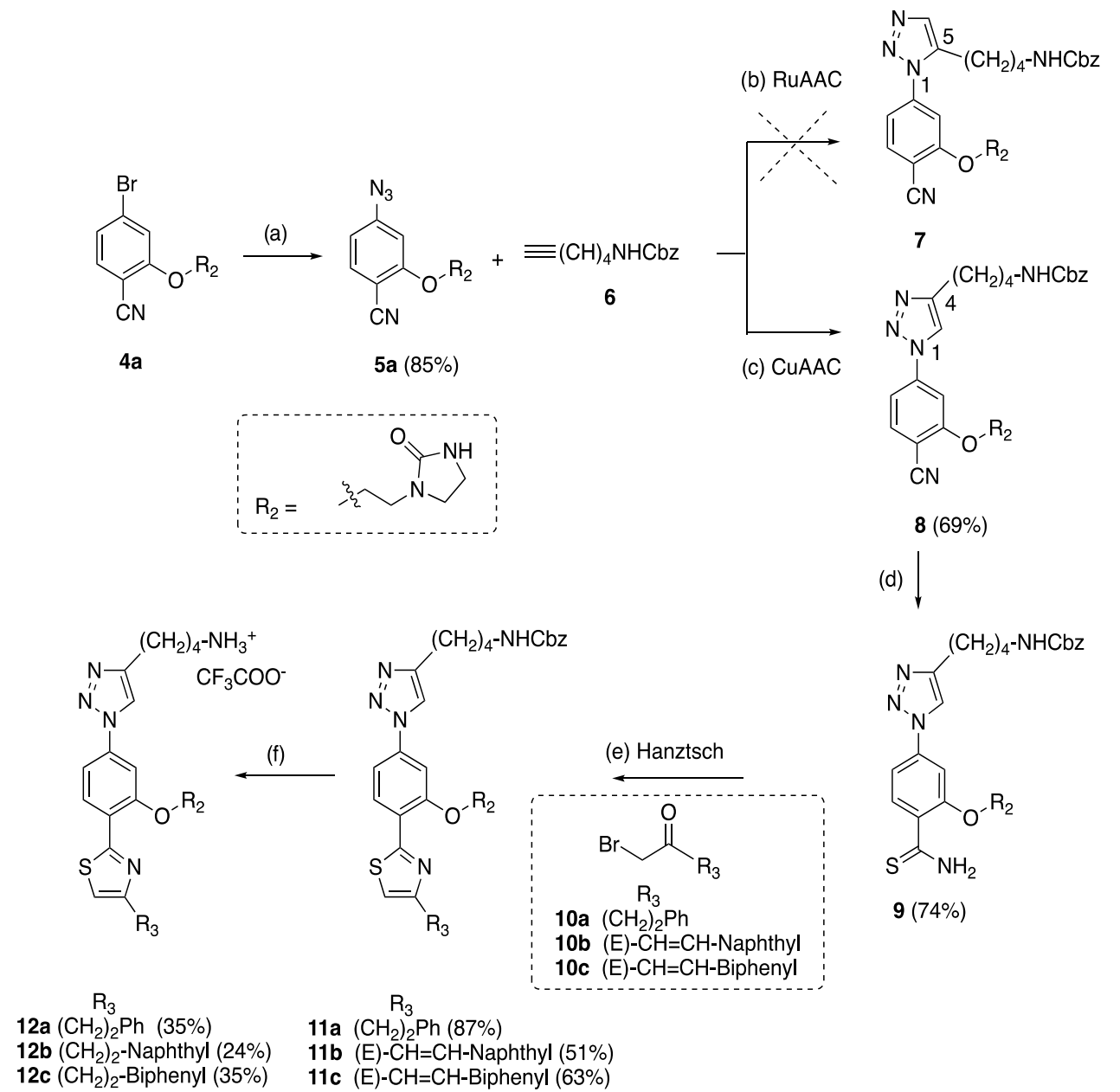

$\mathrm{R}_{3}$

11a $\left(\mathrm{CH}_{2}\right){ }_{2} \mathrm{Ph}(87 \%)$

11b (E) $-\mathrm{CH}=\mathrm{CH}-$ Naphthyl $(51 \%)$

11c (E)- $\mathrm{CH}=\mathrm{CH}-B i p h e n y l(63 \%)$

${ }^{a}$ Reagents and conditions: (a) $\mathrm{NaN}_{3}$, DMSO, molecular sieves $4 \AA$, $100{ }^{\circ} \mathrm{C}, 72 \mathrm{~h}$; (b) $\mathrm{Cp} * \mathrm{RuCI}\left(\mathrm{PPh}_{3}\right)_{2}(5$ or $10 \mathrm{~mol} \%), \mathrm{DMF}, \mathrm{rt}$ to $100{ }^{\circ} \mathrm{C}$; (c)

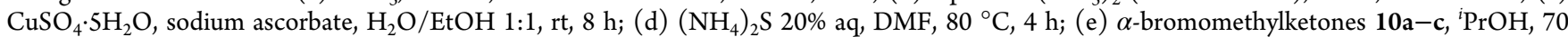
${ }^{\circ} \mathrm{C}, 5 \mathrm{~h}$; (f) $\mathrm{H}_{2}$, Pd/C 10\%, TFA, THF/MeOH 1:1, rt, 2 h.

substituents) was prepared and evaluated. Five of these molecules display activities that very closely resemble that of the peptide prototype $\mathbf{1}$ and likewise behave as noncompetitive, slow-binding inhibitors. ${ }^{41}$ Molecular modeling studies identified a putative binding site for these compounds at an almost unexplored central interfacial cavity of the enzyme and provided a structural rationale to the observed SAR results that was supported by ensuing rational design, synthesis, and activity of a new symmetrical triazole analogue with the desired properties.

\section{RESULTS AND DISCUSSION}

Chemistry. The synthesis of the target triazole-phenylthiazole type I compounds is exemplified by the preparation of the first series of 1,2,3-triazole derivatives $12 a-c$ (bearing $R_{1}-$ $\mathrm{R}_{3}$ substituents similar to those present in the predecessor imidazole analogues 2 and 3), as shown in Scheme 1. The synthetic route started from the previously described bromide intermediate $4 a^{30}$ bearing an imidazolidinone ethyl $R_{2}$ group (used as a Gln mimetic in the previous imidazole derivatives) by treatment with sodium azide in anhydrous dimethyl sulfoxide (DMSO) at $100{ }^{\circ} \mathrm{C}$ for $72 \mathrm{~h}$ to afford the azide intermediate $5 \mathbf{a}$ in $85 \%$ yield. The addition of molecular sieves with pore openings of $4 \AA$ was required to avoid the partial hydrolysis of the azide group to the undesired amine. The next step in the synthetic route was the 1,3-dipolar cycloaddition of the azide intermediate with terminal alkynes substituted with the appropriate $R_{1}$ group (as a Lys mimetic) to generate the 1,2,3-triazole ring. Initial attempts to use the rutheniumcatalyzed azide-alkyne cycloaddition (RuAAC) ${ }^{40 b}$ from 5a and commercially available N-Cbz-protected terminal alkyne 6 in the presence of catalytic amounts (5 or $10 \%$ ) of a cyclopentadienyl $\mathrm{Ru}$ catalyst $\left[\mathrm{Cp} * \mathrm{RuCl}\left(\mathrm{PPh}_{3}\right)_{2}\right]$ at different temperatures in dry dimethylformamide (DMF) and an inert atmosphere did not produce the expected 1,5-disubstituted 1,2,3-triazole 7 . Only unreacted starting materials or complex decomposition mixtures were observed under these conditions. In contrast, the 1,4-disubstituted 1,2,3-triazole regioisomer 8 could be easily obtained in $56 \%$ yield by the 1,3-dipolar copper(I)-catalyzed azide-alkyne cycloaddition (CuAAC) $)^{40 a}$ of azide $\mathbf{5 a}$ and the terminal alkyne $\mathbf{6}$ using the $\mathrm{CuSO}_{4} /$ sodium ascorbate catalyst system at room temperature for $8 \mathrm{~h}$ in $\mathrm{H}_{2} \mathrm{O}$ / $\mathrm{EtOH}(1: 1$ mixture) as the solvent. Subsequent treatment of nitrile 8 with aqueous (aq) $20 \%$ ammonium sulfide at $80{ }^{\circ} \mathrm{C}$ for $4 \mathrm{~h}$ provided the thioamide intermediate 9 in $74 \%$ yield. Next, Hantzsch thiazole synthesis from 1 equiv of 9 and 1 equiv of the commercially available $\alpha$-bromomethylketone 10a or the previously synthesized $10 \mathrm{~b}$ and $10 \mathrm{c}^{30}$ (bearing a 
Table 1. Half-Maximal Inhibitory Concentration $\left(\mathrm{IC}_{50}\right) \pm$ Standard Error (SE) Values for Triazole Compounds I and the Truncated Analogues 13 and 14 in the TryR Oxidoreductase Activity and LiTryR Monomer Displacement Assays ${ }^{a, f}$

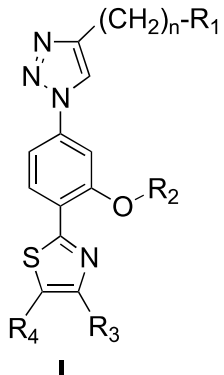

I<smiles>O=C1NCCN1CCOc1cc(Br)ccc1-c1nc(CCc2ccccc2)cs1</smiles>

13<smiles>Cc1cn(-c2ccc(C)c(OCCN3CCNC3=O)c2)nn1</smiles>

14<smiles>[R3]c1csc(-c2ccc(-n3ccnc3C[NH2+]CC[NH3+])cc2OCCN2CCNC2=O)n1</smiles>

reference imidazoles (2 and 3 )

\begin{tabular}{|c|c|c|c|c|c|c|c|}
\hline compounds & $\mathrm{R}_{1}$ & $n$ & $\mathrm{R}_{2}$ & $\mathrm{R}_{3}$ & $\mathrm{R}_{4}$ & $\mathrm{IC}_{50}^{\text {act }}(\mu \mathrm{M})^{b}$ & $\mathrm{IC}_{50}^{\operatorname{dim}}(\mu \mathrm{M})^{c}$ \\
\hline 1 & & & & & & $1.5 \pm 0.2$ & $7.0 \pm 0.6$ \\
\hline 2 & & & & $\left(\mathrm{CH}_{2}\right)_{2}$ naphthyl & & $5.1 \pm 0.4$ & $26 \%^{d}$ \\
\hline 3 & & & & $\left(\mathrm{CH}_{2}\right)_{2}$ biphenyl & & $8.6 \pm 1.4$ & $32 \%^{d}$ \\
\hline $12 a$ & $\mathrm{NH}_{3}^{+}$ & 4 & $\left(\mathrm{CH}_{2}\right)_{2} \operatorname{Im} *$ & $\left(\mathrm{CH}_{2}\right)_{2} \mathrm{Ph}$ & $\mathrm{H}$ & $14.6 \pm 1.0$ & $38.1 \pm 1.2$ \\
\hline $12 b$ & $\mathrm{NH}_{3}^{+}$ & 4 & $\left(\mathrm{CH}_{2}\right)_{2} \mathrm{Im}^{*}$ & $\left(\mathrm{CH}_{2}\right)_{2}$ naphthyl & $\mathrm{H}$ & $5.9 \pm 1.1$ & $7.1 \pm 0.6^{e}$ \\
\hline $12 \mathrm{c}$ & $\mathrm{NH}_{3}^{+}$ & 4 & $\left(\mathrm{CH}_{2}\right)_{2} \operatorname{Im} *$ & $\left(\mathrm{CH}_{2}\right)_{2}$ biphenyl & $\mathrm{H}$ & $10.9 \pm 1.8$ & $4.8 \pm 0.6^{e}$ \\
\hline \multicolumn{8}{|c|}{ Modifications at $\mathrm{R}_{1}$} \\
\hline $12 d$ & $\mathrm{OH}$ & 4 & $\left(\mathrm{CH}_{2}\right)_{2} \mathrm{Im}^{*}$ & $\left(\mathrm{CH}_{2}\right)_{2} \mathrm{Ph}$ & $\mathrm{H}$ & $>75$ & $>75$ \\
\hline $12 \mathrm{e}$ & $\mathrm{CH}_{3}$ & 3 & $\left(\mathrm{CH}_{2}\right)_{2} \operatorname{Im} *$ & $\left(\mathrm{CH}_{2}\right)_{2} \mathrm{Ph}$ & $\mathrm{H}$ & $>75$ & $>75$ \\
\hline $12 \mathrm{f}$ & $\mathrm{CH}_{3}$ & 3 & $\left(\mathrm{CH}_{2}\right)_{2} \mathrm{Im}^{*}$ & $\left(\mathrm{CH}_{2}\right)_{2}$ biphenyl & $\mathrm{H}$ & $>75$ & $>75$ \\
\hline $12 \mathrm{~g}$ & $\mathrm{COOH}$ & 3 & $\left(\mathrm{CH}_{2}\right)_{2} \operatorname{Im} *$ & $\left(\mathrm{CH}_{2}\right)_{2} \mathrm{Ph}$ & $\mathrm{H}$ & $>75$ & $>75$ \\
\hline $12 \mathrm{~h}$ & $\mathrm{NH}_{3}^{+}$ & 3 & $\left(\mathrm{CH}_{2}\right)_{2} \operatorname{Im} *$ & $\left(\mathrm{CH}_{2}\right)_{2} \mathrm{Ph}$ & $\mathrm{H}$ & $20.8 \pm 2.3$ & $>75$ \\
\hline $12 \mathrm{i}$ & $\mathrm{NH}_{3}^{+}$ & 3 & $\left(\mathrm{CH}_{2}\right)_{2} \mathrm{Im}^{*}$ & $\left(\mathrm{CH}_{2}\right)_{2} \mathrm{Biph}$ & $\mathrm{H}$ & $19.7 \pm 3.8$ & $10.8 \pm 0.1$ \\
\hline \multicolumn{8}{|c|}{ Modifications at $\mathrm{R}_{2}$} \\
\hline $12 j$ & $\mathrm{NH}_{3}^{+}$ & 4 & $\mathrm{Me}$ & $\left(\mathrm{CH}_{2}\right)_{2} \mathrm{Ph}$ & $\mathrm{H}$ & $20.1 \pm 2.5$ & $>75$ \\
\hline $12 \mathrm{k}$ & $\mathrm{NH}_{3}^{+}$ & 4 & $\mathrm{Me}$ & $\left(\mathrm{CH}_{2}\right)_{2 \mathrm{~b}}$ iphenyl & $\mathrm{H}$ & $26.8 \pm 5.7$ & $16.1 \pm 0.7$ \\
\hline \multicolumn{8}{|c|}{ Modifications at $\mathrm{R}_{3}$} \\
\hline 121 & $\mathrm{NH}_{3}^{+}$ & 4 & $\left(\mathrm{CH}_{2}\right)_{2} \operatorname{Im} *$ & $\mathrm{O}^{i} \mathrm{Pr}$ & $\mathrm{H}$ & $54.5 \pm 4.4$ & $>75$ \\
\hline $12 \mathrm{~m}$ & $\mathrm{NH}_{3}^{+}$ & 4 & $\left(\mathrm{CH}_{2}\right)_{2} \mathrm{Im}^{*}$ & $\mathrm{CH}_{2}{ }^{t} \mathrm{Bu}$ & $\mathrm{H}$ & $24.1 \pm 1.4$ & $>75$ \\
\hline $12 n$ & $\mathrm{NH}_{3}^{+}$ & 4 & $\left(\mathrm{CH}_{2}\right)_{2} \mathrm{Im}^{*}$ & $\mathrm{Ph}$ & $\mathrm{H}$ & $11.2 \pm 0.2$ & $29.0 \pm 1.5$ \\
\hline 120 & $\mathrm{NH}_{3}^{+}$ & 4 & $\left(\mathrm{CH}_{2}\right)_{2} \mathrm{Im}^{*}$ & $\mathrm{CH}_{2} \mathrm{Ph}$ & $\mathrm{H}$ & $43.6 \pm 1.1$ & $61.2 \pm 2.8$ \\
\hline $12 p$ & $\mathrm{NH}_{3}^{+}$ & 4 & $\left(\mathrm{CH}_{2}\right)_{2} \mathrm{Im}^{*}$ & $\left(\mathrm{CH}_{2}\right)_{3} \mathrm{Ph}$ & $\mathrm{H}$ & $14.6 \pm 1.7$ & $19.1 \pm 1.1$ \\
\hline $12 q$ & $\mathrm{NH}_{3}^{+}$ & 4 & $\left(\mathrm{CH}_{2}\right)_{2} \mathrm{Im}^{*}$ & $\left(\mathrm{CH}_{2}\right)_{2} \mathrm{THQ}^{*}$ & $\mathrm{H}$ & $6.9 \pm 2.1$ & $>75$ \\
\hline $12 \mathrm{r}$ & $\mathrm{NH}_{3}^{+}$ & 4 & $\left(\mathrm{CH}_{2}\right)_{2} \mathrm{Im}^{*}$ & $\left(\mathrm{CH}_{2}\right)_{2} \mathrm{DHB}^{*}$ & $\mathrm{H}$ & $11.9 \pm 0.6$ & $10.7 \pm 0.5$ \\
\hline $12 \mathrm{~s}$ & $\mathrm{NH}_{3}^{+}$ & 4 & $\left(\mathrm{CH}_{2}\right)_{2} \mathrm{Im}^{*}$ & $\left(\mathrm{CH}_{2}\right)_{2} \mathrm{DBF}^{*}$ & $\mathrm{H}$ & $6.6 \pm 1.9$ & $8.8 \pm 0.2$ \\
\hline \multicolumn{8}{|c|}{ Truncated Analogues } \\
\hline 13 & & & & & & $>75$ & $>75$ \\
\hline 14 & & & & & & $>75$ & $>75$ \\
\hline \multicolumn{8}{|c|}{ Modifications at $R_{3}$ and $R_{4}$} \\
\hline $19 \mathrm{a}$ & $\mathrm{NH}_{3}^{+}$ & 4 & $\left(\mathrm{CH}_{2}\right)_{2} \operatorname{Im}^{*}$ & $\mathrm{Ph}$ & $\mathrm{Ph}$ & $4.3 \pm 1.0$ & $7.1 \pm 1.7$ \\
\hline $19 b$ & $\mathrm{NH}_{3}^{+}$ & 4 & $\left(\mathrm{CH}_{2}\right)_{2} \mathrm{Im}^{*}$ & biphenyl & $\mathrm{Ph}$ & $18.4 \pm 3.9$ & $11.3 \pm 0.2$ \\
\hline $19 c$ & $\mathrm{NH}_{3}^{+}$ & 4 & $\left(\mathrm{CH}_{2}\right)_{2} \mathrm{Im}^{*}$ & $\mathrm{PhOPh}$ & $\mathrm{Ph}$ & $16.9 \pm 2.7$ & $9.0 \pm 0.5$ \\
\hline 19d & $\mathrm{NH}_{3}^{+}$ & 4 & $\left(\mathrm{CH}_{2}\right)_{2} \mathrm{Im}^{*}$ & $\left(\mathrm{CH}_{2}\right)_{2}$ biphenyl & $\mathrm{Ph}$ & $19.8 \pm 2.3$ & $5.7 \pm 0.5$ \\
\hline $19 \mathrm{e}$ & $\mathrm{NH}_{3}^{+}$ & 4 & $\left(\mathrm{CH}_{2}\right)_{2} \operatorname{Im} *$ & $\left(\mathrm{CH}_{2}\right)_{2} \mathrm{PhOPh}$ & $\mathrm{Ph}$ & $19.3 \pm 3.7$ & $6.7 \pm 1.0$ \\
\hline
\end{tabular}

${ }^{a}$ Linear peptide $\mathbf{1}$ and imidazole-based compounds $\mathbf{2}$ and 3 were included as reference compounds. ${ }^{b}$ Enzymatic activity $>75$ indicates that the $\mathrm{IC}_{50}$ value is higher than $75 \mu \mathrm{M}$ (maximum assayed). Results are representative of three independent experiments, each performed in triplicate. ${ }^{c}$ Dimer quantitation assay (enzyme-linked immunosorbent assay (ELISA)). ${ }^{25}{ }^{d}$ Percentage of inhibition observed at $20 \mu \mathrm{M}$ as reliable $\mathrm{IC}_{50}$ values could not be determined in this case. ${ }^{e}$ Percentages of inhibition observed at $20 \mu \mathrm{M}$ were 73 and $78 \%$ for $\mathbf{1 2 b}$ and $\mathbf{1 2 c}$, respectively. ${ }^{f_{\text {Im }} *}=$ imidazolidinone, $\mathrm{THQ}^{*}=$ tetrahydroquinoline $(\mathrm{TFA}$ salt $), \mathrm{DHB}^{*}=$ dihydrobenzofuranyl, $\mathrm{DBF}^{*}=$ dibenzofuranyl.

naphthyl or a biphenylethyl hydrophobic $\mathrm{R}_{3}$ substituent) heated in isopropanol at $70{ }^{\circ} \mathrm{C}$ for $36 \mathrm{~h}$ gave the expected $\alpha / \beta$ unsaturated derivatives $11 \mathrm{a}-\mathrm{c}$ monosubstituted at the 4position of the thiazole ring in 87,51 , and $63 \%$ yields, respectively (Scheme 1). Finally, treatment of $11 \mathbf{a}-\mathbf{c}$ with $\mathrm{H}_{2}$, $\mathrm{Pd} / \mathrm{C}$ in tetrahydrofuran (THF)/MeOH mixture in the presence of trifluoroacetic acid (TFA) at room temperature allowed the simultaneous hydrogenolysis of $\mathrm{NHCbz}$ and hydrogenation of the double bond to afford the deprotected target compounds $12 \mathrm{a}-\mathrm{c}$ as monotrifluoroacetate salts in 35, 24 , and $35 \%$ yields, respectively. Chromatographic purification by Biotage using reverse-phase columns was always required to obtain the final compounds with purities higher than $95 \%$ for their biological evaluation. 
Scheme 2. Synthesis of Triazoles Disubstituted at the Thiazole Ring $(19 a-e)^{a}$
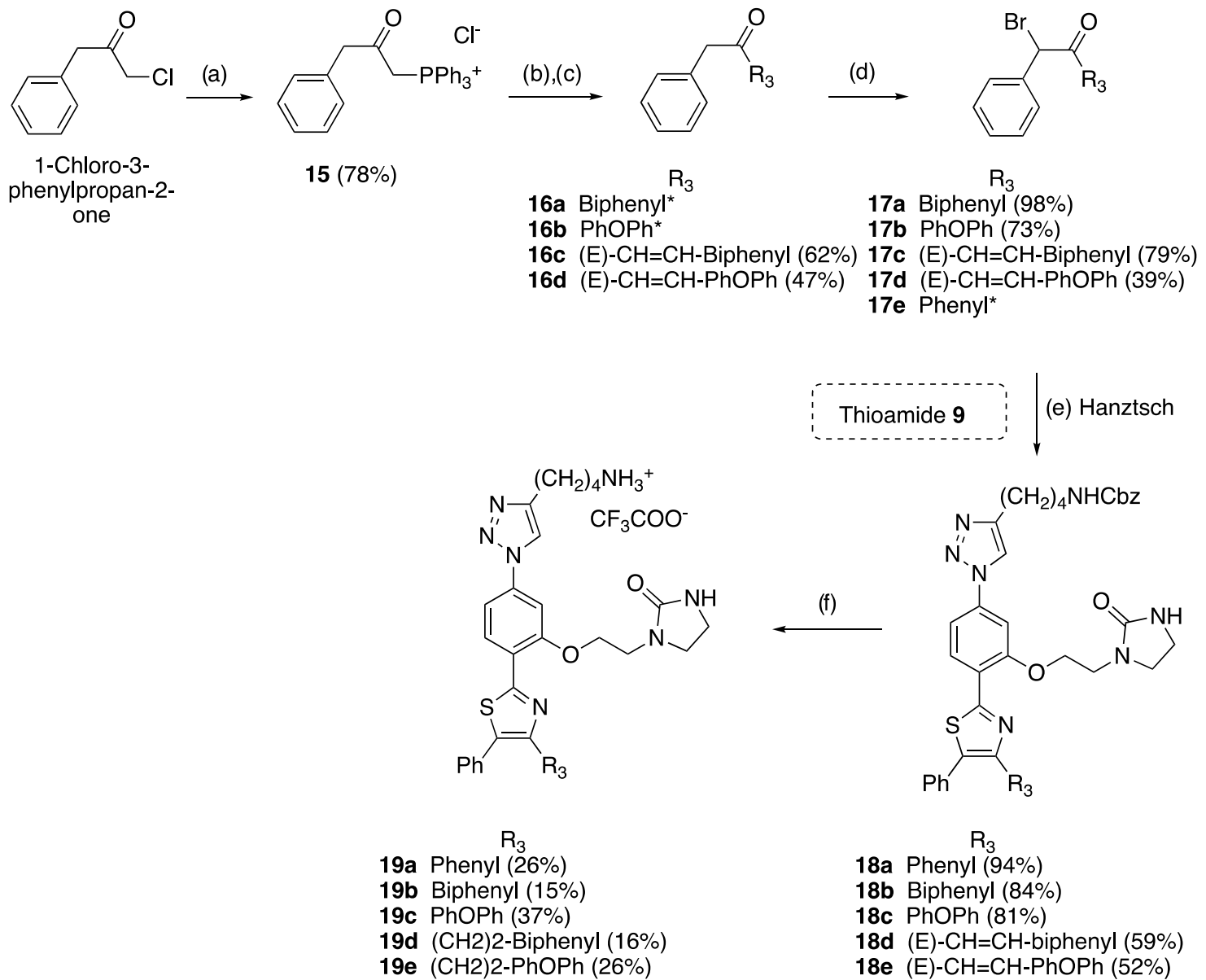

${ }^{a}$ Reagents and conditions: (a) $\mathrm{PPh}_{3}$, dry toluene, $110{ }^{\circ} \mathrm{C}, 6 \mathrm{~h}$; (b) $\mathrm{KOH}$, dry toluene, $110{ }^{\circ} \mathrm{C}, 3 \mathrm{~h}$; (c) RCHO, $110{ }^{\circ} \mathrm{C}, 3 \mathrm{~h}$; (d) NBS, $p$-TsOH, $\mathrm{CH}_{3} \mathrm{CN}$, rt, $14 \mathrm{~h}$; (e) thioamide $9, \mathbf{1 7 a}-\mathrm{e},{ }^{i} \mathrm{PrOH}, 70^{\circ} \mathrm{C}, 5 \mathrm{~h}$; (f) $\mathrm{H}_{2}, \mathrm{Pd} / \mathrm{C} 10 \%$, TFA, THF/MeOH 1:1, rt, 2 h. * Commercially available reagents.

As will be discussed below, the 1,2,3-triazole compounds $12 \mathrm{a}-\mathrm{c}$ emerged as more potent dimerization disruptors of $L i$ TryR than the reference imidazoles and also behaved as strong inhibitors of the oxidoreductase activity of the enzyme. These results prompted us to develop a novel series of triazole derivatives $\mathbf{1 2 d}-\mathbf{s}$ (see structures in Table 1 and Scheme S1) modified at the $R_{1}-R_{3}$ substituents to perform a SAR study. Regarding modifications at $R_{1}$ and $R_{2}$, the protonated aminobutyl group linked to the triazole was replaced by $\mathrm{OH}$, $\mathrm{Me}$, or $\mathrm{COOH}(\mathbf{1 2 d}-\mathbf{g})$ or by a shorter aminopropyl substituent (12h, 12i), while the $\mathrm{R}_{2}$ imidazolidinone (attached to the central phenyl ring through an ethyl linker) was removed $(\mathbf{1 2} \mathbf{j}, \mathbf{1 2} \mathbf{k})$. In terms of $\mathrm{R}_{3}$ modifications, bulky alkyl substituents $(121,12 \mathrm{~m})$ or a phenyl group linked to the thiazole ring through a polymethylene spacer of a different length (12n-p vs 12a) were explored.

Since the presence of a biphenyl or naphthyl substituent at $\mathrm{R}_{3}$ was highly relevant for potent enzyme inhibition and antileishmanial activity, other polyheteroaromatic rings were also explored at $\mathrm{R}_{3}(\mathbf{1 2 q}-\mathbf{s})$. The synthesis of the novel triazole analogues $\mathbf{1 2 d - s}$ involved (i) a high-yielding nucleophilic aromatic substitution $\left(\mathrm{SN}_{\mathrm{Ar}}\right)$ of aryl fluorides with the appropriate alcohols (bearing the $\mathrm{R}_{2}$ substituent), ${ }^{30}$ (ii) CuAAC reactions between azide intermediates and terminal alkynes (containing the $\mathrm{R}_{1}$ substituent), (iii) Hanztsch thiazole synthesis of thioamides with suitable $\alpha$ - bromomethylketones (with the $\mathrm{R}_{3}$ substituent), and (iv) and a final step of catalytic hydrogenation to yield the deprotected final compounds using similar protocols to those described above. It should be noted that in the catalytic hydrogenation of the protected triazole compound intermediate $\mathbf{1 1 q}$ (see Scheme S1) bearing a quinoline moiety as the $\mathrm{R}_{3}$ substituent, the 1,2,3,4-tetrahydroquinoline compound 12q (see Scheme S1) was isolated as a ditrifluoroacetate salt due to the partial hydrogenation and salt formation of the quinoline ring nitrogen atom. The synthetic experimental details of the target 12q-s compounds and the noncommercially available key $\alpha$ bromomethyl-ketone intermediates $10 \mathrm{~m}, 10 \mathrm{p}-\mathrm{s}$ are included in the Supporting Information (see Schemes S1 and S2). Scaffold-truncated simplified compounds (13 and 14, see Table 1), possessing only two aromatic rings and substituents, were also prepared for the SAR studies following similar synthetic protocols (see also the Supporting Information for experimental details; Scheme S3). To further investigate the SAR of the triazole-based compounds, we next focused on the preparation of an additional series of triazole analogues $19 \mathbf{a}-\mathbf{e}$ (Scheme 2) disubstituted at both positions 4 and 5 of the thiazole ring. Polyaromatic groups directly attached or linked through an ethyl spacer to the 4-position and a phenyl group at the 5-position were selected as $R_{3}$ and $R_{4}$ substituents, respectively. As shown in Scheme 2, the preparation of these compounds required the previous synthesis of the non- 
Scheme 3. Synthesis of the Newly Designed Symmetrical Analogue $22^{a}$

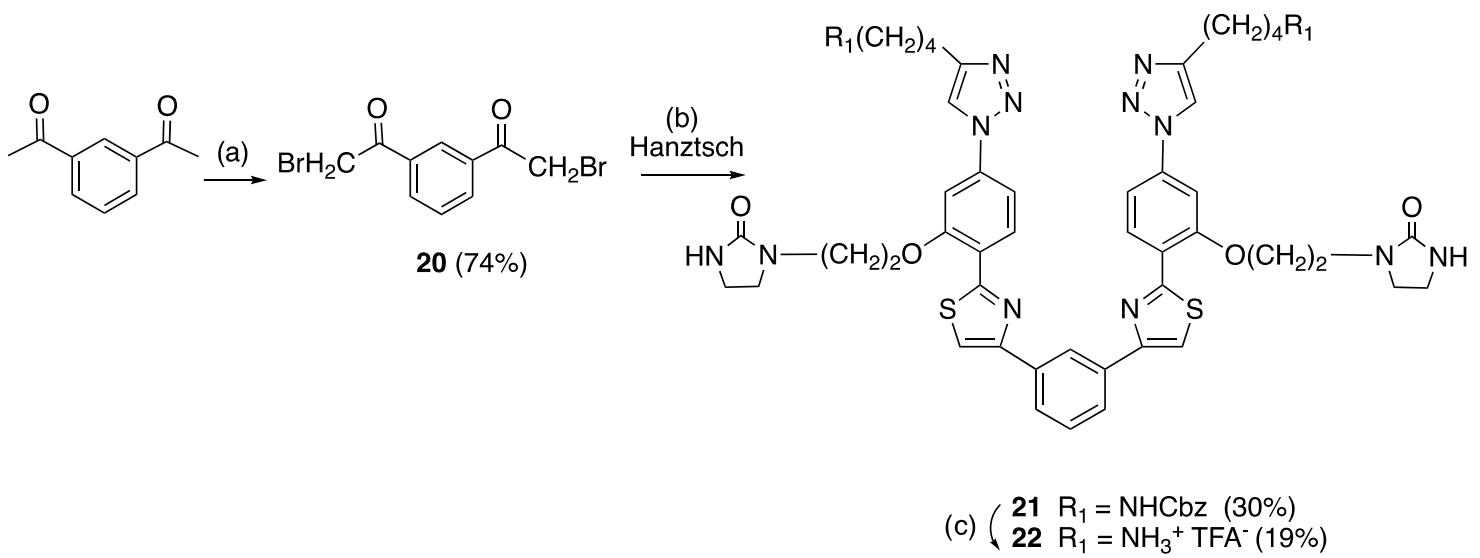

${ }^{a}$ Reagents and conditions: (a) NBS, $p$-TsOH, acetonitrile, rt, 14 h; (b) thioamide 9, ${ }^{i} \mathrm{PrOH}, 70{ }^{\circ} \mathrm{C}, 5$ h; (c) $\mathrm{H}_{2} \mathrm{Pd} / \mathrm{C} 10 \%, \mathrm{TFA}, \mathrm{THF} / \mathrm{MeOH}, 1: 1$, $\mathrm{rt}, 2 \mathrm{~h}$.

commercially available $\alpha$-bromobenzylketones $17 \mathrm{a}-\mathrm{d}$. Thus, $17 a-c$ bearing a biphenyl or a phenyloxyphenyl group at $R_{3}$ directly attached to the carbonyl were synthesized by bromination of the commercially available benzylketones 16a-c with $N$-bromosuccinimide (NBS) in $p$-toluensulfonic acid $(p-\mathrm{TsOH})$ in good to excellent yields.

On the other hand, $\alpha$-bromobenzyl $\alpha, \beta$-unsaturated ketone $17 \mathrm{~d}$ with a polyaromatic group was obtained by regioselective bromination of the most favorable benzylic position with NBS in $p$ - $\mathrm{TsOH}$ of the corresponding benzylketones 16d, which was previously synthesized from 1-chloro-3-phenylpropan-2one by treatment with $\mathrm{PPh}_{3}$ to give the phosphonium salt 15 followed by a Wittig procedure with the corresponding polyaromatic aldehydes in moderate yields. Next, Hantzsch thiazole synthesis from thioamide intermediate 9 with the commercial $17 \mathrm{e}$ or synthetic $\alpha$-bromobenzylketones $17 \mathrm{a}-\mathrm{d}$, followed by catalytic hydrogenolysis of the N-Cbz group and simultaneous olefin hydrogenation of $\mathbf{1 8 a}-\mathbf{e}$ using $10 \% \mathrm{Pd} / \mathrm{C}$ in the presence of TFA, afforded the desired unprotected disubstituted thiazole derivatives $19 \mathbf{a}-\mathbf{e}$ as monotrifluoroacetate salts in low to moderate yields. Finally, we also designed (see section Computational Studies below) and prepared (Scheme 3) a new symmetrical triazole analogue (22) by treating 2 equiv of thioamide intermediate 9 with 1 equiv of $\alpha$ bromomethylketone 20 (previously synthesized by bromination with NBS of commercially available 1,3-diacetyl benzene) under Hantzsch reaction conditions, followed by catalytic hydrogenolysis of the $\mathrm{NHCbz}$ group using similar procedures to those described above.

Biological and Structural Studies. Enzymatic Assays. $L$. infantum TryR Inhibition and Dimerization Assays. All of the novel triazole-phenyl-thiazole modified at substituents $R_{1}-R_{3}$ $(12 a-s)$, disubstituted thiazole analogues bearing $R_{3}$ and $R_{4}$ substituents $(19 a-e)$, and truncated simplified compounds (13 and 14) were evaluated for their effect on both the oxidoreductase activity and the dimerization status of LiTryR. ${ }^{25}$ The prototype peptide $\mathbf{1}$ and imidazole-containing compounds 2 and 3 were used as reference molecules. Screening was performed at different concentrations ranging from 0.1 to $75 \mu \mathrm{M}$. A concentration of $1 \mu \mathrm{M} \mathrm{TS}_{2}$ was used for this initial screening. This low substrate concentration is sufficient for comparison of compound inhibitory activity in the oxidoreductase assay. The best candidates were then characterized further to obtain their dissociation constants. The $\mathrm{IC}_{50}$ values determined in the activity $\left(\mathrm{IC}_{50}^{\text {act }}\right)$ and dimerization $\left(\mathrm{IC}_{50}^{\mathrm{dim}}\right)$ assays are shown in Table 1 .

According to the results obtained with the first series of triazole-based compounds 12a-c (Table 1), analogues containing a naphthyl or a biphenyl group at $R_{3}(12 b, 12 c)$ potently inhibited the TryR oxidoreductase activity, showing similar IC $_{50}^{\text {act }}$ values (in the low micromolar range) to those obtained for the reference imidazole compounds 2 and 3 . Remarkably, 12a-c were much more potent LiTryR dimerization disruptors than their imidazole counterparts. Thus, in contrast to 2 and 3 , for which no reliable $\mathrm{IC}_{50}^{\mathrm{dim}}$ could be measured and only $\sim 30 \%$ dimerization inhibition was observed at a concentration of $20 \mu \mathrm{M}$, the $\mathrm{IC}_{50}^{\mathrm{dim}}$ values for $\mathbf{1 2 b}$, 12c (7.1 and $4.8 \mu \mathrm{M}$, respectively) were similar to (or even slightly lower than) those obtained for the potent prototype peptide 1. Furthermore, replacement of the naphthyl or biphenyl groups at $\mathrm{R}_{3}$ by a phenyl $(\mathbf{1 2 b}, 12 \mathrm{c} v \mathrm{~s}$ 12a) slightly increased the $\mathrm{IC}_{50}^{\text {act }}$ value, while it significantly decreased (in a 5-8-fold range) the ability to disrupt the LiTryR dimer. We took this result as a clear indication that the presence of a polyaromatic substituent at $\mathrm{R}_{3}$ is relevant to potent $L i T r y R$ dimer disruption.

SAR studies on the second series of triazole compounds (12d-s) with variations at the $\mathrm{R}_{1}-\mathrm{R}_{3}$ substituents began with modifications at the $R_{1}$ position. As shown in Table 1 , the presence of a positively charged amino alkyl group at $\mathrm{R}_{1}$ appears as an absolute requirement for inhibition of both activity and dimerization, as evidenced by the complete loss of effect observed when the amino group was replaced by hydroxyl, methyl, or carboxylic acid groups (12d-g vs 12a, 12c). As regards the length of the $R_{1}$ spacer attached to the amino group, shortening the original tetramethylene linker to a trimethylene brought about a $\sim 2$-fold reduction of potency in both assays (12h, 12i vs 12a, 12c). The existence of the imidazolidinone ring as the $\mathrm{R}_{2}$ substituent on the central phenyl ring also appeared important for optimal activity since its removal $(12 \mathrm{j}, 12 \mathrm{k} v s \mathbf{1 2} \mathrm{a}, 12 \mathrm{c})$ resulted in compounds twice or thrice less active in both assays. Modifications at the $\mathrm{R}_{3}$ substituent (located at the 4-position of the thiazole ring) had a pronounced effect on enzymatic activity inhibition and, even more so, on dimerization disruption. Thus, the presence of a (poly)aromatic substituent at $\mathrm{R}_{3}$ was crucial for enhanced 
potency since compounds 121, 12m, with bulky aliphatic groups, exhibit much less inhibitory activity on the enzyme and no destabilization effect on the LiTryR homodimer in comparison with the (poly)aromatic analogues 12a-c. In comparison, varying the length of the linker connecting the phenyl group to the thiazole $(12 \mathbf{n}-\mathbf{p} v s \mathbf{1 2 a})$ turned out to be not so crucial because, in general, it did not significantly affect the inhibitory activity.

In view of these results, and even though the phenylpropyl derivative $12 \mathrm{p}$ displayed the lowest $\mathrm{IC}_{50}^{\mathrm{dim}}$ value, for the next round of modifications, we decided to focus on shortening the propylene linker at $R_{3}$ to an ethylene (12a) or even removing it altogether $(12 n)$ because of the better synthetic accessibility of the corresponding bromoketones. On the other hand, replacement of the naphthyl or the biphenyl group at $\mathrm{R}_{3}$ in the most potent analogues $12 b, 12 c$ by polyheteroaromatics such as a dihydrobenzofuranyl substituent (12r) or a larger hydrophobic tricyclic dibenzofuranyl moiety (12s) also yielded very potent compounds but did not further increase the inhibitory activity of the most potent analogues $(\mathbf{1 2 b}, \mathbf{1 2 c})$ in any of the two assays. In contrast, the introduction of a positively charged tetrahydroquinoline ring (12q) annihilated the dimerization disruption capacity of the molecules even though potent inhibition of the redox activity of the enzyme was retained. In contrast, no activity in any of the assays was observed for the simplified truncated scaffold derivatives 13 and 14, in which the appropriately substituted triazole or thiazole rings were removed. This additional evidence further supports the key role played by these two rings (and the $R_{1}$ and $R_{3}$ substituents) in this type of inhibitor.

Finally, we also evaluated a new series of triazole compounds $(19 a-e)$ disubstituted at the 4- and 5-positions of the thiazole ring with $\mathrm{R}_{3}$ and $\mathrm{R}_{4}$ aromatic moieties. Some of these molecules combined excellent inhibition in the redox assay with potent $L i$ TryR dimer disruption ability. Interestingly, both activities were significantly improved by a factor of $2-4$ for 19a, in which a phenyl group is bonded at both $R_{3}$ and $R_{4}$ positions, in comparison with the $\mathrm{R}_{3}$ phenyl monosubstituted analogue 12n. Introduction of a larger biphenyl or a diphenylether group as the $\mathrm{R}_{3}$ substituent (maintaining the phenyl group at $\mathrm{R}_{4}$ ) significantly decreased the inhibitory activity of the highly potent diphenylsubstituted analogue, but their dimerization disruption ability was affected only slightly (cf. 19b, 19c vs 19a). Also, the combination of $\mathrm{R}_{3}$ polyaromatics attached to the thiazole ring through an ethylene linker with an $\mathrm{R}_{4}$ phenyl group resulted in a significant deleterious effect on the potency of the compounds as inhibitors of the LiTryR oxidoreductase activity, although the potent disrupting effect on dimerization was maintained ( $c f$. 19d, 19e vs 19b, 19c or the corresponding monosubstituted 12c).

In general, the most active compounds in the enzymatic activity assay were also the best dimerization disruptors in the ELISA with the exception of the highly potent tetrahydroquinoline inhibitor 12q, which did not show any dimerization disruption effect, or the thiazole-disubstituted analogues $19 b-$ e, which behave as moderate redox inhibitors but highly potent dimerization disruptors of the enzyme. All in all, our SAR study showed that (i) a positively charged butylamine $\left(\mathrm{R}_{1}\right)$, (ii) an imidazolidinone $\left(R_{2}\right)$ together with a hydrophobic poly(hetero)aromatic group as $\mathrm{R}_{3}(12 \mathrm{~b}, 12 \mathrm{c} ; 12 \mathrm{r}, 12 \mathrm{~s})$ substituents, or (iii) the combination of a phenyl as $R_{3}$ with an additional phenyl as $\mathrm{R}_{4}(19 \mathrm{a})$ are highly relevant to optimal enzyme inhibition and dimerization disruption in this series.

To gain insight into the selectivity of the compounds for $L i$ TryR, representative molecules $12 a-c, 12 n, 12 r$, and 19a were studied as inhibitors of human glutathione-disulfide reductase (hGR), the closest related host enzyme. Remarkably, none of these compounds showed any inhibitory activity against this enzyme. As an example, a comparison of the activities of $L i$ TryR and hGR in the presence of compounds $12 \mathrm{~b}$ and $12 \mathrm{c}$ at $50 \mu \mathrm{M}$ of their respective substrates is shown in Figure S15.

Mechanism of LiTryR Inactivation. As already described for $\mathbf{1},{ }^{41}$ the peptidic precursor of all other compounds, a progressive loss of LiTryR activity is observed during the course of the reaction in the presence of $12 \mathrm{~b}, 12 \mathrm{c}, 12 \mathrm{r}, 12 \mathrm{~s}$, and 19a (Figure 2), selected as the most potent inhibitors in

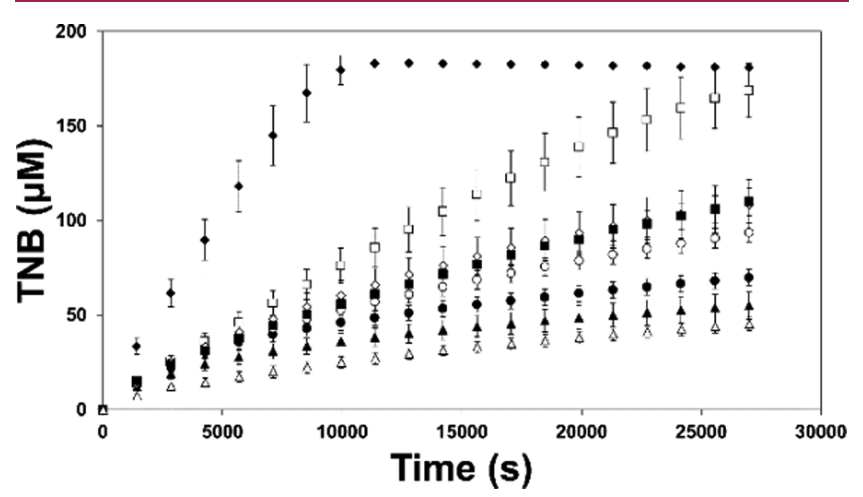

Figure 2. Time-dependent inhibition of $L i T r y R$. Reaction progress curves of LiTryR in the absence $(\checkmark)$ and presence of $25 \mu \mathrm{M}$ mepacrine ( $\square$ ), $10 \mu \mathrm{M}$ peptide $\mathbf{1}(\mathbf{\Delta}), 10 \mu \mathrm{M} \mathbf{1 2 c}(\bigcirc), 10 \mu \mathrm{M} \mathbf{1 2 b}$ (๑), $10 \mu \mathrm{M} 12 \mathrm{r}(\diamond), 10 \mu \mathrm{M} 12 \mathrm{~s}(\mathbf{\square})$, or $10 \mu \mathrm{M} \mathrm{19a}(\triangle)$. [DTNB] = $100 \mu \mathrm{M}$. $[\mathrm{NADPH}]=150 \mu \mathrm{M}$. Data represent the mean $\pm \mathrm{SD}$ of three independent experiments.

these series. In stark contrast, reaction rates in the presence of the classical competitive inhibitor mepacrine are almost constant until 5,5'-dithiobis(2-nitrobenzoic acid) (DTNB) (which allows substrate regeneration) is exhausted. The progress curves of the reactions in the presence of the selected compounds are typical of slow-binding inhibitors. ${ }^{42 a, b}$

Despite the loss of activity observed during the reaction, dependency of the initial velocities $\left(v_{\mathrm{i}}\right)$ on 19a and $\mathrm{TS}_{2}$ concentrations could be fitted to a model in which a rapid equilibrium is reached between the free enzyme and inhibitor $(\mathrm{E}+\mathrm{I})$ and the enzyme/inhibitor (EI) complex (Scheme 4). This analysis, based on $v_{i}$ values, was performed both in a DTNB-coupled assay and in a direct NADPH-oxidation assay

Scheme 4. Two-Step Mechanism of Time-Dependent Inhibition of $\operatorname{LiTryR}^{a}$

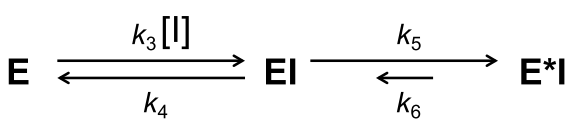

${ }^{a}$ The first step is a rapid equilibrium that generates the enzymeinhibitor (EI) complex. This process is governed by the association rate $\left(k_{3}\right)$ and the dissociation rate $\left(k_{4}\right)$ constants. The second step consists of slow and reversible inactivation of the enzyme that is governed by the forward isomerization rate constant $\left(k_{5}\right)$ and the much smaller reverse rate constant $\left(k_{6}\right)$. 
$3.1 \mu \mathrm{M} \mathrm{TS}_{2}$

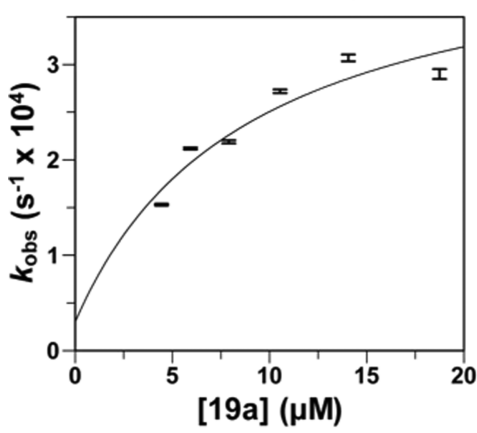

$25 \mu \mathrm{M} \mathrm{TS}{ }_{2}$

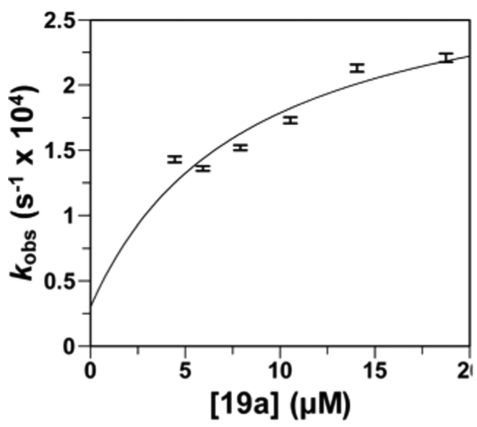

$6.2 \mu \mathrm{M} \mathrm{TS} S_{2}$

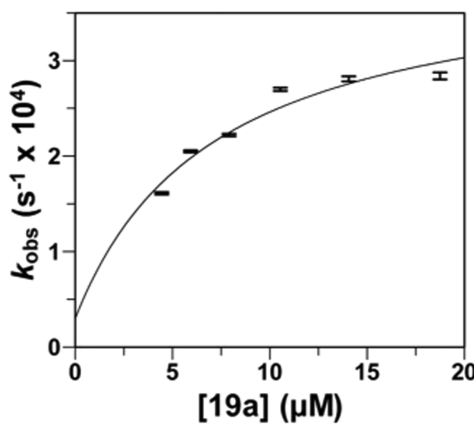

$50 \mu \mathrm{M} \mathrm{TS}$

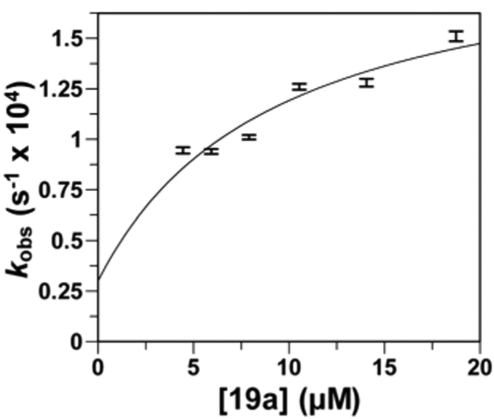

$12.5 \mu \mathrm{M} \mathrm{TS}_{2}$

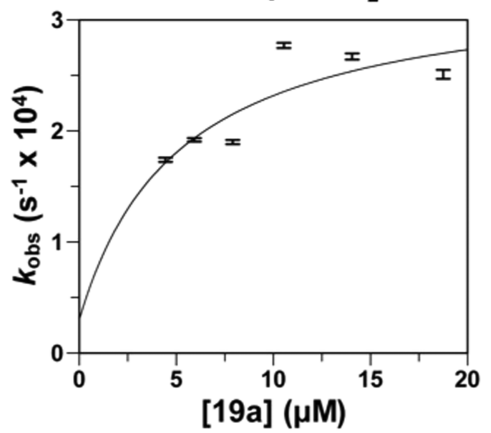

$100 \mu \mathrm{M} \mathrm{TS}{ }_{2}$

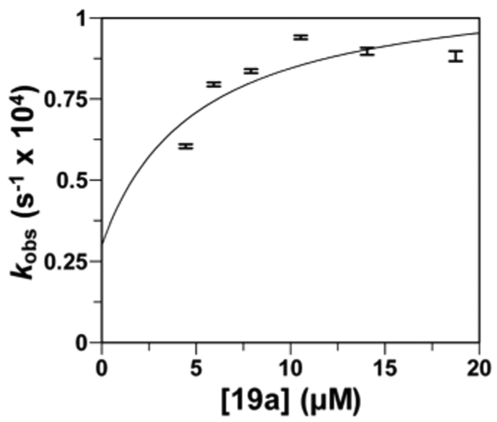

Figure 3. Concentration dependence of the observed rate constants of $L i T r y R(0.8 \mathrm{nM})$ inactivation by 19a at different $\mathrm{TS}_{2}$ concentrations. Plot of the $k_{\mathrm{obs}}$ values ( \pm standard errors) as a function of $19 \mathrm{a}$ concentration at six different $\mathrm{TS}_{2}$ concentrations $(3.1,6.2,12.5,25,50$, and $100 \mu \mathrm{M})\left(k_{\mathrm{obs}}\right.$ determinations for every 19a concentration at the different fixed $\mathrm{TS}_{2}$ concentrations assayed are shown in the Supporting Information). Curves were fitted using eq 2 , and the results of the fits are shown in Table 2.

(Figure S1 and Table S1). Our data consistently reveal a nonlinear noncompetitive hyperbolic inhibition mechanism.

Peptide 1 has already been described as a pseudoirreversible time-dependent noncompetitive inhibitor that is able to promote a two-step process of enzyme isomerization (Scheme 4). ${ }^{41}$ The kinetic data obtained for 19a, the most potent compound, were also analyzed considering a similar mechanism of enzyme inactivation.

In this inactivation model, a rapid and reversible primary inhibition event generates an enzyme-inhibitor binary complex (EI complex). The process of generating an inactive form of $L i$ TryR upon 19a binding is governed by $k_{5}$ and $k_{6}$ first-order rate constants, which describe an isomerization equilibrium between the initial enzyme-inhibitor complex (EI) and a second high-affinity complex (E*I) (Scheme 4). This slow isomerization process gives rise to a characteristic bending of the reaction curve that is defined by the first-order rate constant $k_{\mathrm{obs}}$, whose value describes the conversion from the initial reaction rate $\left(v_{\mathrm{i}}\right)$ to the final steady-state velocity $\left(v_{\mathrm{s}}\right)$.

Adjustment to eq 1 (see equations in Experimental Section) of the progress curves of the reactions catalyzed by LiTryR allowed us to obtain the $k_{\text {obs }}$ values for six 19a concentrations $(4.4,5.9,7.9,10.5,14.1$, and $18.7 \mu \mathrm{M})$ at six different $\mathrm{TS}_{2}$ concentrations $(3.1,6.2,12.5,25,50$, and $100 \mu \mathrm{M}$ ) (Figures S2-S7 and Table S2). The different $k_{\text {obs }}$ values obtained at each substrate concentration can be used to determine the apparent inhibitory constants $K_{\mathrm{i}}^{\text {app }}$ and $K_{\mathrm{i}}^{* \text { *app }}$ defined as the dissociation constant for the initial EI complex and the constant for the overall dissociation from $\mathrm{E}^{*} \mathrm{I}$ to $\mathrm{E}+\mathrm{I}$, respectively (eq 2). ${ }^{42 \mathrm{a}, \mathrm{b}}$ Based on the relationship among $k_{\mathrm{obs}}$, $v_{\mathrm{i}}$, and $v_{\mathrm{s}}\left(k_{6}=k_{\mathrm{obs}} \times v_{\mathrm{i}} / v_{\mathrm{s}}\right)$ at all of the trypanothione disulfide $\left(\mathrm{TS}_{2}\right)$ and 19a concentrations assayed, $k_{6}$ varies between $3.9 \times$ $10^{-6}$ and $6.5 \times 10^{-5} \mathrm{~s}^{-1}$. Taking into consideration the extremely slow process of recovery of the enzymatic activity after complete inactivation of LiTryR (400 nM) upon incubation with $25 \mu \mathrm{M} \mathrm{19a}$ for $16 \mathrm{~h}$ and subsequent 2500 fold dilution (Figure S13), a value of $3 \times 10^{-5} \mathrm{~s}^{-1}$ was selected as a conservative upper value for $k_{6}$. Fixing this value for $k_{6}$ rendered very good estimations of $K_{\mathrm{i}}^{\text {app }}$ and $K_{\mathrm{i}}{ }^{* a p p}$ after the fitting process for all of the substrate concentrations assayed (Figure 3 and Table 2).

The relationships between the different $K_{\mathrm{i}}^{\text {app }}$ and $K_{\mathrm{i}}$ values in slow-binding inhibitors are the same as those for classical linear reversible inhibitors. ${ }^{42 \mathrm{a}, \mathrm{b}}$ By applying eq 3 to fit the $K_{\mathrm{i}}^{\text {app }}$ values obtained at the six different $\mathrm{TS}_{2}$ concentrations assayed (Figure S8A), we could estimate the values of $\alpha(0.8 \pm 0.4)$

Table 2. Apparent Inhibition Constants for LiTryR TimeDependent Inhibition by $19 \mathrm{a}^{a}$

$\begin{array}{ccc}{\left[\mathbf{T S}_{2}\right](\boldsymbol{\mu} \mathbf{M})} & K_{\mathrm{i}}^{\text {app }}(\boldsymbol{\mu} \mathbf{M}) & K_{\mathrm{i}}^{* \text { *app }}(\boldsymbol{\mu} \mathbf{M}) \\ 3.1 & 8.9 \pm 3.1 & 0.6 \pm 0.1 \\ 6.2 & 7.2 \pm 1.7 & 0.5 \pm 0.1 \\ 12.5 & 5.2 \pm 2.6 & 0.5 \pm 0.2 \\ 25 & 8.3 \pm 3.0 & 0.8 \pm 0.2 \\ 50 & 9.3 \pm 3.2 & 1.4 \pm 0.3 \\ 100 & 5.0 \pm 2.7 & 1.3 \pm 0.6\end{array}$

${ }^{a} K_{\mathrm{i}}^{\text {app }}$ and $K_{\mathrm{i}}^{* \text { app }}$ values at different $\mathrm{TS}_{2}$ concentrations were obtained by fitting to eq 2 the $k_{\text {obs }}$ values for every 19a concentration at the different fixed $\mathrm{TS}_{2}$ concentrations assayed. Results are the estimated values of the nonlinear regression \pm associated standard errors. 
and $K_{\mathrm{i}}(7.8 \pm 1.7 \mu \mathrm{M})$. A similar approach (eq 4 and Figure $\mathrm{S} 8 \mathrm{~B})$ was followed to estimate the values of $\alpha^{*}(5.5 \pm 2.9)$ and $K_{\mathrm{i}}^{*}(0.5 \pm 0.1 \mu \mathrm{M})$ for the two-step global process of enzyme inhibition. According to these results, formation of the initial EI complex is not affected by the presence of substrate, a behavior that is characteristic of a pure noncompetitive process $(\alpha \sim 1)$. The isomerization step from EI to $\mathrm{E}^{*} \mathrm{I}$ strongly enhances the inhibitory activity of $19 \mathrm{a}$, which is characterized by an overall $K_{\mathrm{i}}^{*}$ value of $0.5 \mu \mathrm{M}$. This isomerization process is, as expected, slightly impaired by the presence of substrate ( $\alpha=5.5$ ) because of the generation of the enzyme-substrateinhibitor complex, which decreases the concentration of the EI complex and thereafter the rate of $\mathrm{E}^{*} \mathrm{I}$ generation. Despite this small substrate effect, an $\alpha$ value of 5.5 for the overall process is still in the range of $\alpha$ values characteristic of noncompetitive (mixed) inhibitors. The overall inhibitory process is depicted in Scheme S5. Because of the ability of 19a to cause enzyme dissociation, the characteristic isomerization of the enzyme in this mechanism of slow-binding inhibition is expected to be related to homodimer disruption.

Interestingly, compounds $\mathbf{1 2 b}$ and $\mathbf{1 2 q}$ have similar $\mathrm{IC}_{50}$ values in the reductase assay but only $\mathbf{1 2 b}$ interferes with dimerization. The kinetic analyses reveal that both compounds are time-dependent inhibitors but only inhibition caused by 12b follows a two-step process of enzyme isomerization (Figure S11 and Table S3). Plots of $k_{\mathrm{obs}}$ vs inhibitor concentration for $12 \mathrm{q}$ fit to a straight line that is indicative of a single-step binding mechanism (Figure S12, Table S4, and Scheme S4), which agrees with its inability to disrupt the homodimer.

Computational Studies. Despite numerous attempts to form cocrystals with LiTryR or soak crystals of the enzyme with moderately or highly potent triazole-based dimerization disruptors 12a, 12b, and the heteroaromatic 12r, no diffraction-quality crystal containing an enzyme/drug complex could be obtained. Of note, similar problems were encountered in previous cocrystallization efforts with the predecessor imidazoles 2 and $3 .^{30}$ Because of these so-far insurmountable hurdles, we had to rely on molecular modeling tools to try and shed light on the atomistic details of the binding process. Docking the most potent triazoles $12 \mathrm{~b}, \mathbf{1 2 c}$ into the cavity of one LiTryR monomer that lodges the ${ }^{435}$ Pro- $\mathrm{Met}^{447} \alpha$-helix of the other monomer, while feasible, failed to account for the SAR results discussed above. Indeed, the biologically essential naphthyl or biphenyl $\mathrm{R}_{3}$ substituents could not be properly accommodated unless the ligand folded onto itself in an unrealistic fashion due to lack of room. Therefore, we sought alternative binding sites in $L i T r y R$, as found in Protein Data Bank (PDB) entry 2JK6 ${ }^{22 \mathrm{~b}}$ using the FTMap web server. ${ }^{43}$ This procedure highlighted the existence of a large, hydrophobic, and putatively druggable cavity right at the center of the dimer that is lined by residues from both monomers and located very close to the interfacial helices that were mimicked by the original peptides and peptidomimetics (Figure 4).

Interestingly, this central cavity at the LiTryR dimer interface is reminiscent of that present in Plasmodium falciparum $\mathrm{GR}^{44}$ or $\mathrm{hGR}$ and is shown to bind some noncompetitive or uncompetitive inhibitors such as safranin, menadione, ${ }^{45}$ xanthenes, ${ }^{46}$ or $\mathrm{N}$-arylisoalloxazines. ${ }^{47}$ Ligand accessibility to this site was assessed by means of the CAVER web server, ${ }^{48}$ which identified several tunnels connecting this intermonomer cavity to the bulk solvent (Figure 5).

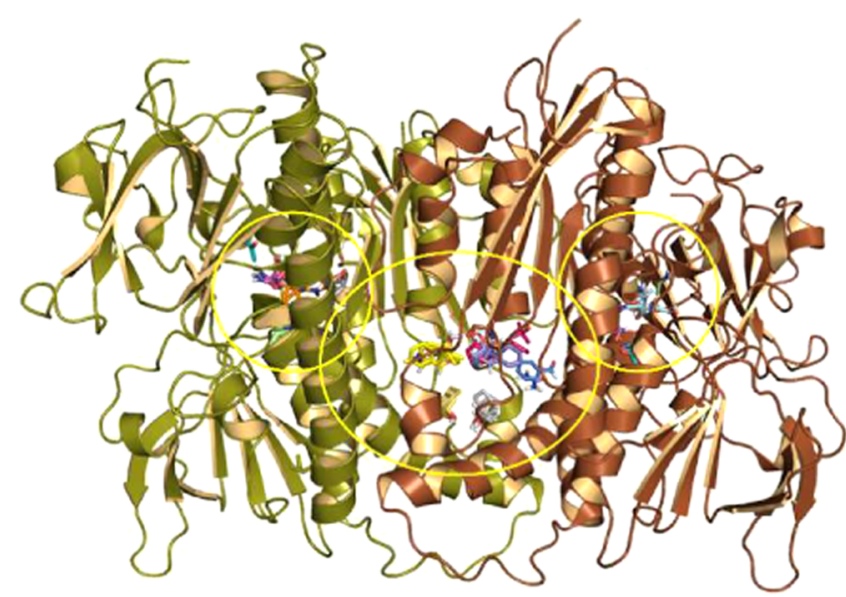

Figure 4. LiTryR dimer structure. FTMap identified the central interfacial cavity and the two adjacent sites where the two FAD cofactors are lodged as putative ligand-binding sites (circled by yellow lines).

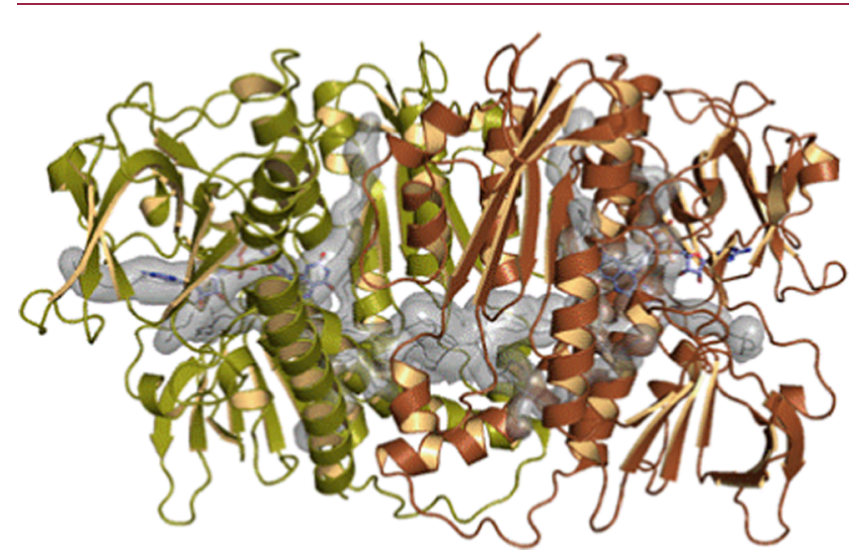

Figure 5. Visualization of the potential access routes from the bulk solvent to the interfacial cavity ( $2.808 \AA^{3}, 0.77$ "druggability") as determined by the CAVER Web server using default parameters. ${ }^{48}$ In comparison, each nicotinamide adenine dinucleotide phosphate (NADP) binding site occupies $1.343 \AA^{3}$ and its druggability is 0.63 . The tunnels are depicted as a continuous semitransparent gray surface. The central vertical $\alpha$-helices encompass the amino acid residues originally identified as hotspots for dimerization. The FAD prosthetic groups are displayed as stick models for reference purposes only.

We next performed docking studies with the most potent triazole dimerization inhibitors $\mathbf{1 2 b}, \mathbf{1 2 c}$ and the disubstituted thiazole analogue 19a centering the search within the proposed interfacial cavity of the LiTryR homodimer (Figure 6). The best ligand poses had in common the positioning of the (hetero)aromatic scaffold inside the connection tunnel and the terminal ammonium group of the $R_{1}$ substituent at the hydrogen-bonding distance from the carboxylate of Glu466' $\left(d\left(\mathrm{~N}_{12 \mathrm{~b}} \cdots \mathrm{O}_{\mathrm{Glu} 466^{\prime}}\right)=2.2 \AA, d\left(\mathrm{~N}_{12 \mathrm{c}} \cdots \mathrm{O}_{\mathrm{Glu}_{466^{\prime}}}\right)=3.4 \AA\right)$.

The proposed binding modes also revealed the potential of the imidazolidinone group of the $\mathrm{R}_{2}$ substituent to act as a hydrogen bond acceptor from the hydroxyl group of either Thr65 $\left(d\left(\mathrm{~N}_{12 \mathrm{~b}} \cdots \mathrm{O}_{\mathrm{Thr} 65}\right)=2.9 \AA\right)$, for the naphthyl compound $12 b$, or Ser433' $\left(d\left(\mathrm{~N}_{12 c} \cdots \mathrm{O}_{\mathrm{Ser} 433^{\prime}}\right)=2.5 \AA\right)$, for biphenyl compounds $12 \mathrm{c}$ and $19 \mathrm{~b}$. The unhindered rotation of the central benzene ring of the scaffold seems to play a fundamental role to distinctly orient the $R_{2}$ substituent in each complex. Regarding the $\mathrm{R}_{3}$ hydrophobic substituents at 
(a)

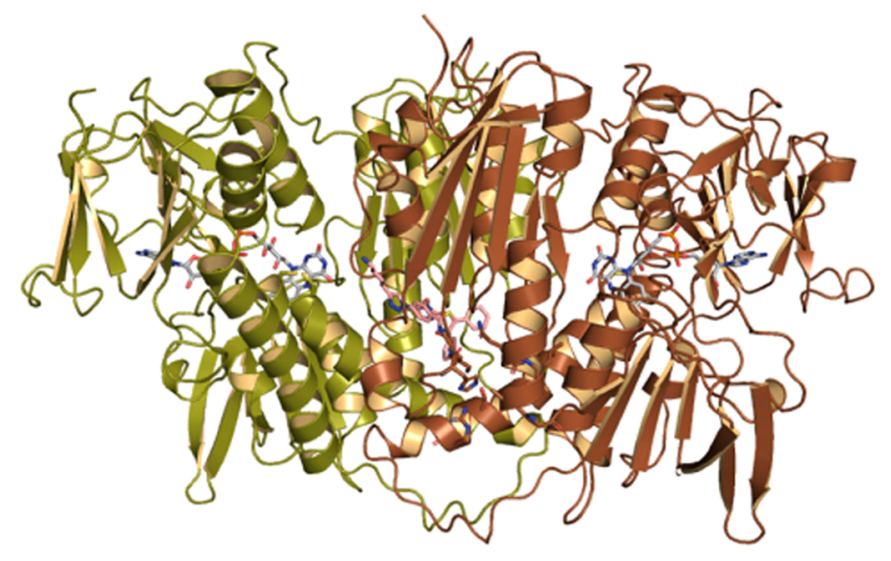

(c)

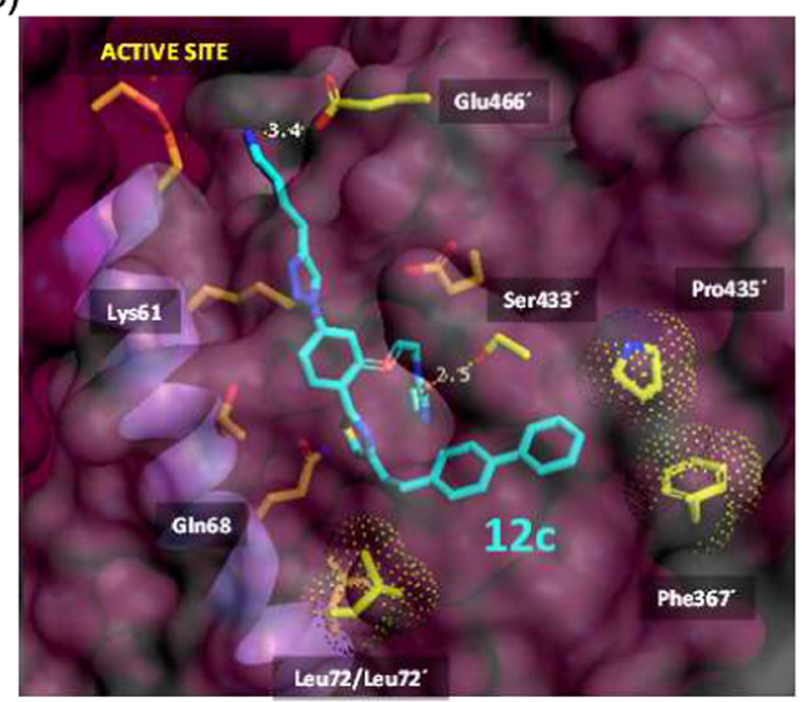

(b)

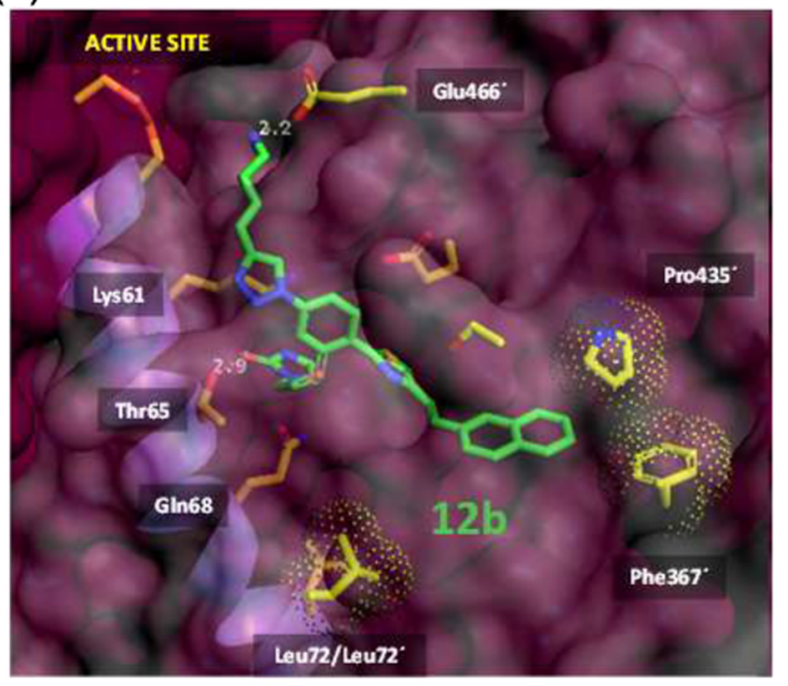

(d)

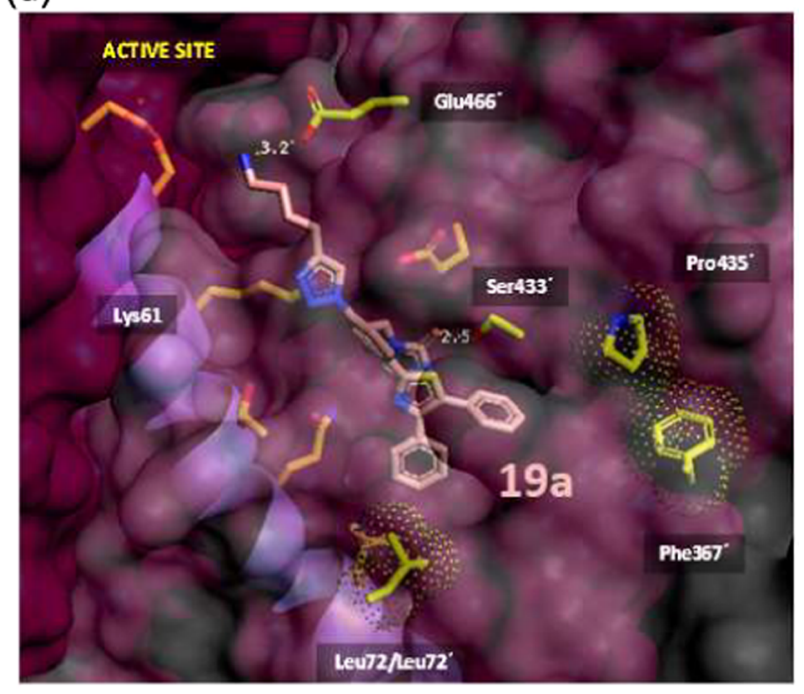

Figure 6. Proposed ligand-binding modes within LiTryR. (a) Cartoon representation of dimeric LiTryR showing the two FAD prosthetic groups (sticks, $\mathrm{C}$ atoms in gray) close to the active sites and a docked 19a molecule ( $\mathrm{C}$ atoms in pink) filling half of the central interfacial hydrophobic cavity and part of the tunnel connecting it to the bulk solvent. (b) Details of the best-scoring binding pose for $\mathbf{1 2 b}$ (C atoms in green). (c) Details of the best-scoring binding pose for $12 \mathrm{c}$ ( $\mathrm{C}$ atoms in cyan). (d) Details of the best-scoring binding pose for 19a (C atoms in pink).

the thiazole, the bulky naphthyl and biphenyl aromatic groups for compounds $\mathbf{1 2 b}, \mathbf{1 2 c}$ could be accommodated in one of the hydrophobic subpockets of the interfacial cavity that is mainly defined by Pro435' and Phe367', in good accord with the previous FTMap results. In addition, for the $R_{3}$ and $R_{4}$ disubstituted phenyl-thiazole analogue 19a, one of the phenyl groups attached to the thiazole ring was found to point directly toward the second hydrophobic subpocket Leu72-Leu72' at the bottom of the cavity, another location pinpointed by FTMap. This binding mode nicely accounts for the abovementioned dramatic improvement of inhibitory potency relative to the monosubstituted phenyl-thiazole $\mathbf{1 2 n}$.

Our molecular dynamics simulations and binding energy decomposition results using 19a as a representative inhibitor point to Glu436 as one of the major contributors to ligand binding (see Figure S16 and Movie S1 in the Supporting Information). We have previously shown that this residue is a hotspot for $L i$ TryR dimerization. ${ }^{25}$ Indeed, in all X-ray crystal structures of TryR, this glutamate's carboxylate from one monomer is involved in two short hydrogen bonds with the peptide backbone of Ser464 and Ala465 from the other monomer. Inhibitor binding appears to promote the loss of these interdimer hydrogen-bonding interactions (Figure S17) due to a wedge effect brought about by hydrophobic interactions involving the phenyl rings on the one side of the molecule and strong electrostatic interactions on the other side, which involve not only the free amino group but also the triazole ring. Indeed, the negative electrostatic potential generated by the two unsubstituted ring nitrogens faces the positive dipole of the short ${ }^{400}{ }^{M e t G l y}{ }^{405} \alpha$-helix. Taken together, the theoretical calculations provide a rationale for the observed SAR results. Furthermore, the residue in hGR (PDB id: 1XAN) that is positionally equivalent to Leu72 in LiTryR is Phe78, whose aromatic side chain provides a flat platform for the stacking of ligands such as safranin or xanthene $\mathrm{e}^{45,46}$ but prevents the binding of our novel compounds, hence their remarkable selectivity. The central cavity putatively targeted by $19 \mathrm{a}$ and analogues is lined by the 

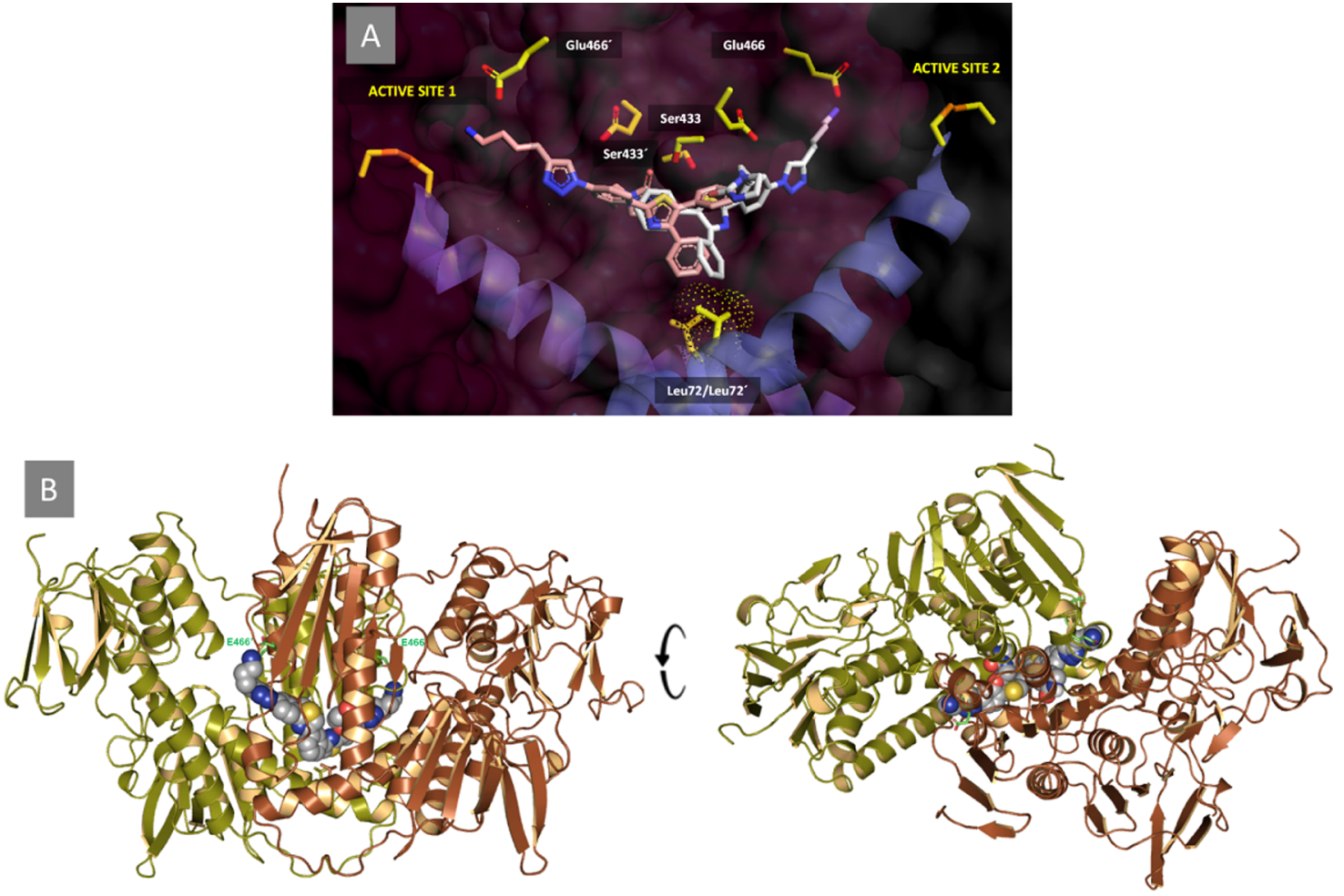

Figure 7. Rationale for the design of the $C_{2}$-symmetric compound 22. (A) Best docking pose for 19a (C atoms in pink) with the tail extended into one LiTryR monomer reproduced for the other monomer (C atoms in white). Note how the propylamino group is extended and oriented toward the carboxylate of Glu466 in both cases. (B) Best-scoring result provided by the automated docking program ${ }^{49}$ for 22 (CPK model) inside the central interfacial cavity and connecting tunnels. The side chains of Glu466 and Glu466' are displayed as sticks with C atoms colored in green.

residues listed in Table S5, which also shows the positionally equivalent residues in hGR. The overall lack of identity in several crucial regions is in consonance with the observed marked selectivity for TryR.

To further support the feasibility of the proposed binding mode and improve the binding affinity for the putative target site, a new $C_{2}$-symmetric compound $\mathbf{2 2}$ was rationally designed with a view to exploiting the $C-2$ symmetry of this homodimeric enzyme and simultaneously occupy both entrance/exit tunnels (Figure 5). The putative LiTryR/19a complex provided the starting point for the structure-based design. As shown in Figure 7A, reproducing the binding mode of 19a within one monomer on the other monomer immediately reveals the possibility of merging both single molecular entities into one by making use of a suitable linker bonded to the $\mathrm{R}_{3}$ substituent. To this end, a 1,3-disubstituted phenyl was selected as an appropriate spacer to yield the $C_{2}$ symmetric compound 22, which was also docked into the putative binding site (Figure $7 \mathrm{~B}$ ).

The good agreement found between the intended binding mode for $\mathbf{2 2}$ and that found by the automated docking program $^{49}$ (Figure 7) is noteworthy. In addition to the hydrophobic contacts between the aromatic rings and the walls of the cavity, the two terminal $\mathrm{R}_{1}$ butylammonium groups of $\mathbf{2 2}$ are presumed to establish simultaneous salt bridges with Glu466/Glu467 and Glu466'/Glu467', whereas the carbonyl groups of the two imidazolidinone moieties can establish hydrogen bonds with the protonated nitrogens of Lys61/ Lys61', the side-chain carboxamide of Gln68, and the backbone NH of Ser433/Ser433'.

The activity of the new symmetric compound 22 was evaluated in the two enzymatic assays. Encouragingly, the compound emerged not only as the most effective LiTryR inhibitor of the entire series, with an $\mathrm{IC}_{50}^{\text {act }}$ value of $0.4 \pm 0.03$ $\mu \mathrm{M}$, but also as a very potent dimerization disruptor $\left(\mathrm{IC}_{50}^{\mathrm{dim}}=\right.$ $8.0 \pm 0.2 \mu \mathrm{M})$. In comparison with the corresponding monomeric triazole ligand $12 \mathrm{n}$ (substituted with an $\mathrm{R}_{3}$ phenyl group), 22 was 28 - and 4-fold more potent, respectively, in both assays (see Table 1). Taken together, these experimental results support the proposed binding mode of the monomeric and symmetric triazole-based compounds at this interfacial site.

Inhibitory Activity on Other TryR Enzymes from the Trypanosoma Genus. TryR is an essential enzyme not only for Leishmania but also for Trypanosoma parasites. Given the high degree of identity/similarity among the amino acid sequences of TryRs from these two genera, some degree of activity against so closely related enzymes would not be unexpected for our compounds. To test this hypothesis, the most active members of these series were tested as inhibitors of the oxidoreductase activity of TryRs from T. brucei (TbTryR) and Trypanosoma congolense (TcoTryR), the causative agents of sleep sickness and nagana, respectively. The results shown in Table 3 demonstrate, in fact, very similar activities for $12 \mathbf{a}-\mathbf{c}$, 12n, 12r, 19a, and 22 as inhibitors of the three enzymes.

In Vitro Antileishmanial Evaluation and Cytotoxicity. Compound Internalization into the Parasites. Our earlier attempts to develop LiTryR dimerization disruptors as leishmanicidal molecules were hampered by the poor ability of previously synthesized compounds to cross the parasite plasma membrane. The peptidomimetics herein described, endowed with fluorescent properties, no longer suffer from this limitation. Figure 8 shows the intense blue fluorescence emitted by promastigotes incubated for $1 \mathrm{~h}$ with compound 12a. Strong fluorescent spots can be observed in the apical 
Table 3. $\mathrm{IC}_{50} \pm$ SE Values $(\mu \mathrm{M})$ for Selected Triazole Analogues 12a-c, 12n, 12r, 19a, and 22 in the Oxidoreductase Activity of TryR from L. infantum, T. brucei, and $T$. congolense

\begin{tabular}{crrr} 
compounds & \multicolumn{1}{c}{ LiTryR } & \multicolumn{1}{c}{ TbTryR } & \multicolumn{1}{c}{ TcoTryR } \\
12a & $14.6 \pm 1.0$ & $13.3 \pm 1.9$ & $11.0 \pm 1.3$ \\
12b & $5.9 \pm 1.1$ & $9.7 \pm 2.1$ & $4.8 \pm 1.9$ \\
12c & $10.9 \pm 1.8$ & $10.0 \pm 2.5$ & $4.8 \pm 1.8$ \\
12n & $9.0 \pm 0.2$ & $12.5 \pm 1.9$ & $9.3 \pm 0.8$ \\
12r & $11.9 \pm 0.6$ & $15.0 \pm 2.9$ & $10.1 \pm 1.4$ \\
19a & $4.3 \pm 1.0$ & $7.3 \pm 0.6$ & $5.6 \pm 0.8$ \\
22 & $0.4 \pm 0.03$ & $1.0 \pm 0.3$ & $0.5 \pm 0.1$ \\
\hline
\end{tabular}

region of some parasites, just opposite the flagellar pocket that is expected to be the main entry region for these compounds.

Activity on Extracellular Parasites and Human Cells. Representative examples of triazole-based LiTryR enzyme inhibitors were tested in vitro against $L$. infantum axenic promastigotes and amastigotes. Cytotoxicity was assessed employing the human liver cancer cell line HepG2. Miltefosine, the $\mathrm{R}_{9}$ conjugate of the prototype peptide $\mathbf{1}$, and imidazole-based compounds $\mathbf{2}$ and $\mathbf{3}$ were included as reference drugs. According to the data shown in Table 4, among the 18 triazole compounds tested, 9 showed halfmaximal effective concentration $\left(\mathrm{EC}_{50}\right)$ values below $10 \mu \mathrm{M}$ against Leishmania promastigotes or amastigotes (12b, 12c, $12 \mathrm{i}-\mathrm{k}, 12 \mathrm{n}, 19 \mathrm{~b}, 19 \mathrm{~d}$, and 19e) that are similar to those observed for the reference compounds.

Of all the compounds bearing a butylamine at $\mathrm{R}_{1}$, an imidazolidinone at $R_{2}$, and different $R_{3}$ substituents $(12 a-c)$, the biphenylethyl analogue $12 \mathrm{c}$ displayed better activity against both promastigotes and amastigotes than those containing naphthyl or phenylethyl substituents $(12 c>12 b>12 a)$ and also lower cytotoxicity. This results in an improved selectivity index (SI) of 8.8 for promastigotes $\left(\mathrm{SI}_{\mathrm{p}}\right)$ and 3.7 for amastigotes $\left(\mathrm{SI}_{\mathrm{a}}\right)$ in comparison with the SIs of the corresponding biphenyl imidazole analogue $3\left(\mathrm{SI}_{\mathrm{p}}=\mathrm{SI}_{\mathrm{a}}=\right.$ 2.7). On the other hand, a combination of a shorter propyl spacer at $R_{1}$ and the biphenyl group at $R_{3}$ gave $12 i$, the most potent and selective compound of the entire series, with $\mathrm{EC}_{50}$ values of 5.8 against promastigotes $\left(\mathrm{EC}_{50 \mathrm{p}}\right)$ and $5.2 \mu \mathrm{M}$ against amastigotes $\left(\mathrm{EC}_{50 \mathrm{a}}\right)$ and the highest SIs $\left(\mathrm{SI}_{\mathrm{p}}=10.4\right.$ and $\mathrm{SI}_{\mathrm{a}}=$ 11.6). The imidazolidinone moiety at $R_{2}$ could be eliminated without compromising the leishmanicidal activity $(\mathbf{1 2} \mathbf{j}, \mathbf{1 2} \mathbf{k})$, but a significant increase in cytotoxicity was detected, which suggests a positive effect of the imidazolidinone on reducing the cytotoxicity. As regards $\mathrm{R}_{3}$, the biphenylethyl substituent could be replaced by a phenyl resulting in an equipotent leishmanicidal analogue (12c vs 12n), in contrast to the higher $\mathrm{IC}_{50}$ values observed for $12 \mathrm{n}$ in the enzymatic assays. However, the SI for 12n was low due to an increase in toxicity. The introduction of polyheteroaromatic rings gave rise to a significant reduction of the leishmanicidal activity $(12 q-s$ s 12c) in contrast to the high potency observed for these analogues in the enzymatic assays. Disubstituted thiazole analogues $19 \mathrm{a}-\mathrm{e}$ also showed high leishmanicidal activities against amastigotes with $\mathrm{EC}_{50}$ values in the 8.4-22.6 $\mu \mathrm{M}$ range but, with the exception of 19c, low SIs $($ SI $<2.5)$ due to higher toxicities. Remarkably, the symmetrical triazole analogue 22 turned out to be one of the most potent and selective agents against $L$. infantum amastigotes with an $\mathrm{EC}_{50 \mathrm{a}}$ value of $4.9 \mu \mathrm{M}$ and a $\mathrm{SI}_{\mathrm{a}}$ of 6.2.

It should be noted that a direct correlation between in vitro TryR inhibitory activity and in cellulo effects is not to be expected due to differences in cellular permeability or the possibility that this enzyme is not the only target for these compounds. Therefore, among the newly tested triazole-based analogues, the propylamine biphenyl derivative $12 \mathbf{i}$ and the $C$ 2 symmetric 22 displayed the best leishmanicidal activity and the lowest in cellulo cytotoxicity with SI values that exceeded those obtained for the imidazoles 2 and 3 by $5-6$-fold. It is interesting to point out that, despite the relatively poor $\mathrm{IC}_{50}$ value obtained for $12 \mathrm{i}$ in the oxidoreductase activity assay, its behavior in the dimerization assay is similar to that of the most potent compounds from these series. This finding suggests that their ability to disrupt the dimer may be largely responsible for the leishmanicidal activity of these compounds. As $\mathrm{IC}_{50}$ values were calculated taking into consideration only the initial velocities of the reactions and because of the time-dependent behavior of these molecules, compounds such as $12 \mathrm{i}$ may show good activities in the dimerization assay while displaying poor $\mathrm{IC}_{50}$ values.

Leishmanicidal Activity in Intracellular Amastigotes. The most potent and selective compounds were further tested for their leishmanicidal activity in amastigote-infected THP-1 cells. The $\mathrm{EC}_{50}$ values obtained are summarized in Table 5. Miltefosine, edelfosine, amphotericin $\mathrm{B}$, the $\mathrm{R}_{9}$-conjugate of the prototype peptide $\mathbf{1}$, and compounds 2 and 3 from the precursor imidazole series were included as reference compounds. In our view, the fact that the $\mathrm{EC}_{50}$ values cover a range from 22 to $>75 \mu \mathrm{M}$ indicates that not all of the compounds are able to cross the plasma and phagolysosomal membranes in the macrophages. Among the monomeric triazole-based compounds, only the phenyl derivative 12a, with an $\mathrm{EC}_{50}$ value of $32.4 \mu \mathrm{M}$, and the biphenyl derivatives

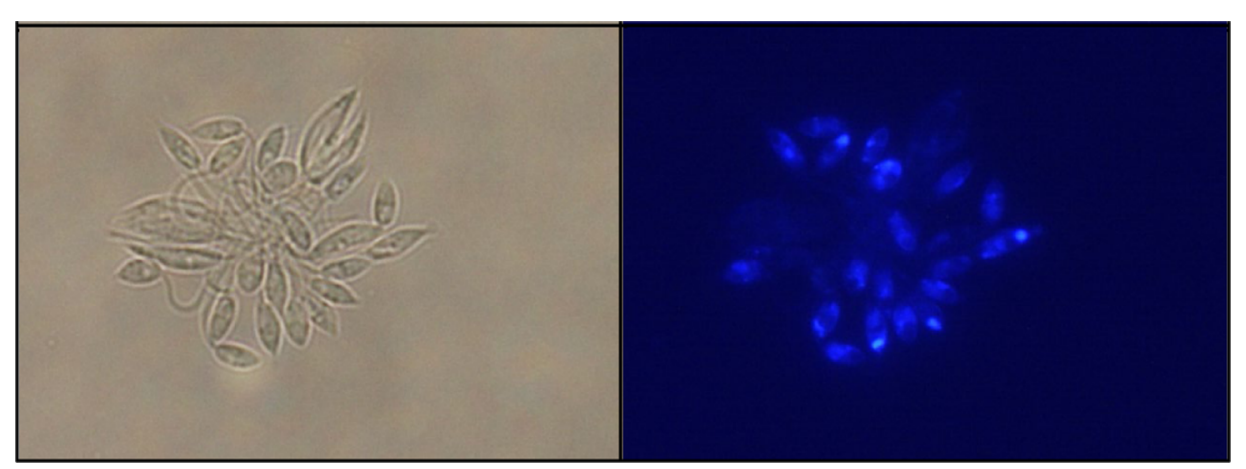

Figure 8. Fluorescence microscopy images of $L$. infantum promastigotes treated with $25 \mu \mathrm{M}$ compound 12a for $1 \mathrm{~h}$. 
Table 4. In Vitro Activity on L. infantum Parasites and Cytotoxic Activity of Representative Triazole Compounds ${ }^{a, b}$

\begin{tabular}{|c|c|c|c|c|}
\hline compounds & $\mathrm{EC}_{50}(\mu \mathrm{M})$ promastigotes $^{c}$ & $\mathrm{EC}_{50}(\mu \mathrm{M})$ amastigotes $^{c}$ & $\mathrm{EC}_{50}(\mu \mathrm{M}) \mathrm{HepG} 2^{c, d}$ & $\mathrm{SI}_{\mathrm{p}} / \mathrm{SI}_{\mathrm{a}}{ }^{e}$ \\
\hline $12 \mathrm{a}$ & $16.4 \pm 0.9$ & $13.9 \pm 0.6$ & $20.3 \pm 2.4$ & $1.2 / 1.5$ \\
\hline $12 b$ & $8.4 \pm 0.3$ & $15.3 \pm 1.7$ & $33.3 \pm 2.7$ & $4.0 / 2.2$ \\
\hline $12 \mathrm{c}$ & $4.9 \pm 0.4$ & $11.6 \pm 0.8$ & $43.1 \pm 2.6$ & $8.8 / 3.7$ \\
\hline $12 \mathrm{~h}$ & $12.7 \pm 0.3$ & $31.6 \pm 5.8$ & $25.7 \pm 2.2$ & $2.0 /<1$ \\
\hline $12 \mathrm{i}$ & $5.8 \pm 0.7$ & $5.2 \pm 0.3$ & $60.4 \pm 3.0$ & $10.4 / 11.6$ \\
\hline $12 j$ & $8.5 \pm 0.1$ & $7.1 \pm 0.7$ & $12.4 \pm 0.7$ & $1.8 / 1.7$ \\
\hline $12 \mathrm{k}$ & $\mathrm{ND}^{f}$ & $4.0 \pm 0.2$ & $7.4 \pm 0.6$ & $\mathrm{ND} / 1.9$ \\
\hline $12 \mathrm{~m}$ & $42.6 \pm 3.9$ & $25.2 \pm 0.5$ & $44.9 \pm 1.3$ & $1.0 / 1.8$ \\
\hline $12 n$ & $5.4 \pm 0.08$ & $11.5 \pm 0.3$ & $16.4 \pm 2.3$ & $3.0 / 1.4$ \\
\hline 120 & $>75$ & $>75$ & $67.9 \pm 1.5$ & $<1.0 /<1.0$ \\
\hline $12 q$ & ND & $27.0 \pm 2.8$ & $43.3 \pm 1.0$ & $\mathrm{ND} / 1.6$ \\
\hline $12 r$ & $23.8 \pm 0.5$ & $22.3 \pm 0.6$ & $29.4 \pm 0.7$ & $1.2 / 1.3$ \\
\hline $12 \mathrm{~s}$ & ND & $68.8 \pm 3.2$ & $>75$ & $\mathrm{ND} />1.1$ \\
\hline 19a & $10.7 \pm 1.3$ & $15.6 \pm 3.0$ & $26.5 \pm 4.1$ & $2.5 / 1.7$ \\
\hline $19 b$ & ND & $9.4 \pm 0.5$ & $17.3 \pm 0.1$ & $\mathrm{ND} / 1.8$ \\
\hline 19c & ND & $22.6 \pm 5.7$ & $\geq 75$ & $\mathrm{ND} / \geq 3.3$ \\
\hline 19d & ND & $9.1 \pm 0.2$ & $12.1 \pm 0.1$ & $\mathrm{ND} / 1.3$ \\
\hline $19 \mathrm{e}$ & ND & $8.4 \pm 0.1$ & $6.6 \pm 0.6$ & $\mathrm{ND} /<1$ \\
\hline 22 & $3.8 \pm 0.1$ & $4.9 \pm 0.2$ & $30.5 \pm 4.1$ & $8.0 / 6.2$ \\
\hline miltefosine & $47.6 \pm 0.6$ & $2.0 \pm 0.1$ & $>75$ & $>1.6 />37.5$ \\
\hline $\mathrm{R}_{9}$-peptide 1 & $3.1 \pm 0.6$ & $3.4 \pm 0.2$ & $61.7 \pm 6.1$ & $19.9 / 18.1$ \\
\hline 2 & $12.8 \pm 0.7$ & $12.8 \pm 1.3$ & $27.1 \pm 2.4$ & $2.1 / 2.1$ \\
\hline 3 & $5.3 \pm 0.3$ & $5.3 \pm 0.2$ & $14.2 \pm 0.9$ & $2.7 / 2.7$ \\
\hline
\end{tabular}

${ }^{a}$ Miltefosine, linear peptide $\mathbf{1}$ conjugated to $\mathrm{R}_{9}$, and imidazole-containing compounds $\mathbf{2}$ and $\mathbf{3}$ were included as in-house reference compounds. ${ }^{b}$ Results are representative of three independent experiments, each performed in triplicate. $\mathrm{EC}_{50} \pm \mathrm{SE}$ values are indicated. ${ }^{{ }^{c}}$ The half-maximal effective concentration $\left(\mathrm{EC}_{50}\right)$ is defined as that causing a $50 \%$ reduction of proliferation in $L$. infantum promastigotes $\left(\mathrm{EC}_{50 \mathrm{p}}\right)$ and amastigotes $\left(\mathrm{EC}_{50 \mathrm{a}}\right)$ or human hepatocellular carcinoma (HepG2) cells. Dead parasites were identified by their increased permeability to propidium iodide (PI). ${ }^{d}$ Cytotoxicity in HepG2 cells was measured using the crystal violet method. ${ }^{e}$ The selectivity index (SI) is the ratio of $\mathrm{EC}_{50}$ against human cells to $\mathrm{EC}_{50}$ against $L$. infantum promastigotes $\left(\mathrm{SI}_{\mathrm{p}}\right)$ and amastigotes $\left(\mathrm{SI}_{\mathrm{a}}\right) .{ }^{{ }_{\mathrm{ND}}} \mathrm{ND}=$ not determined.

12c, 12i, with $\mathrm{EC}_{50}$ values of 46.5 and $54.5 \mu \mathrm{M}$, respectively, displayed moderate effectiveness against intracellular amastigotes. Interestingly, the symmetric triazole molecule $\mathbf{2 2}$ emerged, once again, as the most potent and selective leishmanicidal compound of all of the triazole-based series $\left(\mathrm{EC}_{50}=22 \mu \mathrm{M}\right)$, showing a SI of 2.2, better than that obtained for edelfosine $(S I=1.4)$. Accordingly, derivatives 12a, 12c, 12i, and 22 constitute the first analogues designed against the dimerization interface of TryR that show leishmanicidal activity toward intracellular amastigotes. These results confirm the interest and potential of both monomeric and symmetric triazole-based compounds as antileishmanial agents.

\section{CONCLUSIONS}

The development of new and more efficient antileishmanial drugs is a priority in the field of neglected tropical diseases. From a small library of 26 triazole-phenyl-thiazole compounds, we have identified the most potent small-molecule dimerization disruptors of LiTryR described to date. Similar to prototype peptide $\mathbf{1}$, they behave as slow-binding, noncompetitive inhibitors with overall $K_{\mathrm{i}}^{*}$ values of $0.5 \mu \mathrm{M}$ (19a). These molecules are also endowed with high antileishmanial activity against both extracellular and intracellular parasites and improved selectivity indexes when compared to those obtained for previous in-house imidazolebased compounds.

Molecular modeling studies carried out for the most potent LiTryR triazole-containing dimerization inhibitors 12b, 12c, and 19a identified a previously unexplored but apparently druggable binding site consisting of a large central cavity at the dimer interface of the enzyme. In the absence of crystallographic evidence, despite extensive efforts, this putative binding mode provided a rationale for the observed SAR and a basis for the subsequent structure-based design of a new symmetrical triazole analogue $\mathbf{2 2}$ that displays improved LiTryR inhibitory activities over those of its parental monomeric triazole. This rationally designed compound shows a dramatic enhancement in leishmanicidal potency, in particular against intracellular amastigotes.

All in all, our results provide the first evidence for ligand binding to a so-far unexplored region of LiTryR and lay the ground for further design of innovative TryR inhibitors that may become valuable candidates in the process of discovering new drugs against leishmaniasis.

\section{EXPERIMENTAL SECTION}

Chemical Procedures. Experiments dealing with air- and watersensitive reagents/compounds were performed in an argon atmosphere. Hygroscopic species were previously dried under vacuum for $24 \mathrm{~h}$ by $\mathrm{P}_{2} \mathrm{O}_{5}$ as the drying agent. Unless otherwise noted, analyticalgrade solvents and commercially available reagents were used without further purification. Anhydrous $\mathrm{CH}_{2} \mathrm{Cl}_{2}$ was dried by refluxing over $\mathrm{CaH}_{2}$. EtOH was dried with $4 \AA$ molecular sieves previously activated in a microwave oven. THF was dried by reflux over sodium/ benzophenone. Pressured reactions were carried out on a SigmaAldrich Ace Glass flask (50 or $100 \mathrm{~mL}$ ) supplied with a Teflon cap. Microwave-assisted experiments were performed on a Biotage Initiator 2.0 single-mode cavity instrument from Biotage (Uppsala). Experiments were carried out in sealed microwave reaction vials at the standard absorbance level ( $400 \mathrm{~W}$ maximum power). Lyophilizations were carried out on a Telstar 6-80 lyophilizer. 
Table 5. In Vitro Antileishmanial Activity for the Most Representative Triazole-Based Compounds in AmastigoteInfected THP-1 Monocyte-Derived Macrophages ${ }^{a}$

\begin{tabular}{|c|c|c|}
\hline compounds & $\begin{array}{c}\mathrm{EC}_{50}(\mu \mathrm{M}) \text { intracellular } \\
\text { amastigotes }^{b}\end{array}$ & $\mathrm{EC}_{50}(\mu \mathrm{M}) \mathrm{THP}-1^{c}$ \\
\hline $12 \mathrm{a}$ & $32.4 \pm 6.7$ & $45 \pm 3.1$ \\
\hline $12 b$ & $>75$ & $>75$ \\
\hline $12 \mathrm{c}$ & $46.5 \pm 1.5$ & $\begin{array}{l}>75(100 \% \text { at } \\
\quad 75 \mu \mathrm{M})^{d}\end{array}$ \\
\hline $12 \mathrm{i}$ & $54.4 \pm 15.5$ & $\begin{array}{l}>75(100 \% \text { at } \\
\quad 75 \mu \mathrm{M})^{d}\end{array}$ \\
\hline $12 q$ & $>75$ & $>75(67 \% \text { at } 75 \mu \mathrm{M})^{d}$ \\
\hline $19 c$ & $>75$ & $>75(63 \% \text { at } 75 \mu \mathrm{M})^{d}$ \\
\hline 22 & $22.2 \pm 6.4$ & $48.4 \pm 14.5$ \\
\hline mdelfosine & $2.5 \pm 0.02$ & $3.5 \pm 0.3$ \\
\hline miltefosine & $0.6 \pm 0.1$ & $>25$ \\
\hline amphotericin B & $0.07 \pm 0.01$ & $>5$ \\
\hline $\mathrm{R}_{9}$-peptide 1 & $>75$ & $14.5 \pm 2.9$ \\
\hline 2 & $>75$ & $27.9 \pm 4.4$ \\
\hline 3 & $>75$ & $15.5 \pm 1.8$ \\
\hline
\end{tabular}

${ }^{a}$ Edelfosine, miltefosine, and amphotericin $\mathrm{B}$ were included as reference leishmanicidal drugs. The $\mathrm{R}_{9}$-peptide $\mathbf{1}$ and the imidazolecontaining compounds 2 and 3 were included as in-house reference compounds for structure-activity comparisons. ${ }^{b}$ The half-maximal effective concentration $\left(\mathrm{EC}_{50}\right)$ is defined as that causing a $50 \%$ reduction in the number of $L$. infantum amastigotes per cell in the culture or amastigote-infected THP-1 monocyte-derived macrophages. Living intracellular amastigotes were identified by their green fluorescence due to green fluorescent protein (GFP) expression and their lack of permeability to propidium iodide; $\mathrm{EC}_{50} \pm \mathrm{SE}$ values are indicated. ${ }^{c}$ Cytotoxicity was assessed in THP-1 monocyte-derived macrophages by measuring lactate dehydrogenase (LDH) activity. ${ }^{d}$ Cell viability of amastigote-infected THP-1 monocyte-derived macrophages at $75 \mu \mathrm{M}$ (maximum concentration assayed). Results are representative of three independent experiments.

Monitoring of the reactions was performed by analytical thin-layer chromatography (TLC) on silica gel $60 \mathrm{~F}_{254}$ (Merck) or by highperformance liquid chromatography coupled to mass spectrometry (HPLC-MS) using a Waters Alliance 2695 Separation Module with a Waters Micromass ZQ Detector.

Compounds were purified by (a) flash column chromatography (Merck) with silica gel 60 (230-400 mesh); (b) high-performance flash column chromatography (HPFC) on a Biotage Isolera One using cartridges of Claricep i-Series, Silica, $40 \mathrm{~g}(40-60 \mu \mathrm{m}, 60 \AA)$ for normal phase chromatography, and KP-C18-HS $12 \mathrm{~g}\left(21 \times 55 \mathrm{~mm}^{2}\right)$ for the reverse phase; (c) centrifugal circular thin-layer chromatography (CCTLC) on a Chromatotron (Kiesegel $60 \mathrm{PF}_{254}$ gipshaltig, Merck), with layer thicknesses of 1 and $2 \mathrm{~mm}$ and flow rates of 2 and $3 \mathrm{~mL} / \mathrm{min}$; or (d) semipreparative HPLC purifications on a Waters 2695 HPLC system equipped with a Photodiode Array 2998 coupled to a 3100 Mass Detector mass spectrometer using a C18 Sunfire column $(19 \mathrm{~mm} \times 150 \mathrm{~mm})$.

The purity of the compounds was checked by analytical HPLC on a Waters 600 system equipped with a C18 Sunfire column $(4.6 \mathrm{~mm} \times$ $150 \mathrm{~mm}, 3.5 \mu \mathrm{m})$ and a selectable wavelength UV detector. Alternatively, an Agilent Technologies 1120 Compact LC provided with a reverse-phase column ACE 5 C18-300 $(4.6 \mathrm{~mm} \times 150 \mathrm{~mm}, 3.5$ $\mu \mathrm{m})$ and integrated diode detector PDA 996 was used. As the mobile phase, mixtures of $\mathrm{A}\left(\mathrm{CH}_{3} \mathrm{CN}\right)$ and $\mathrm{B}\left(\mathrm{H}_{2} \mathrm{O}\right)(0.05 \% \mathrm{TFA})$ on isocratic or gradient mode with a flow rate of $1 \mathrm{~mL} / \mathrm{min}$ were used. The following gradients were used: from $10 \% \mathrm{~A}$ to $100 \% \mathrm{~A}$ in $10 \mathrm{~min}$ (gradient A) and from 1\% A to $100 \% \mathrm{~A}$ in $10 \mathrm{~min}$ (gradient B). The purity of the final compounds was also determined to be $>95 \%$ by elemental analysis with a LECO CHNS-932 apparatus. Deviations of the elemental analysis results from the calculated value were within $\pm 0.4 \%$.
Melting points (m.p.) were measured on a Mettler Toledo M170 apparatus and are uncorrected. Infrared (IR) spectra were recorded on a PerkinElmer Spectrum One instrument and $\mathrm{KBr}$ pellet as a sample support. Mass spectrum (MS) on electrospray ionization (ESI) mode was recorded on a Hewlett-Packard 1100SD in positive mode. High-resolution mass spectra (HRMS) were obtained on an Agilent 6520 Accurate-Mass Q-TOF LC-MS equipped with an HP1200 (Agilent) liquid chromatograph coupled to a mass spectrometer with a Q-TOF 6520 hybrid mass analyzer. Usually, an error equal to or lower than $5 \mathrm{ppm}$ was allowed. Nuclear magnetic resonance (NMR) spectra were recorded on a Varian INNOVA-300 operating at $300 \mathrm{MHz}\left({ }^{1} \mathrm{H}\right)$ and $75 \mathrm{MHz}\left({ }^{13} \mathrm{C}\right)$, a Varian INNOVA-400 operating at $400 \mathrm{MHz}\left({ }^{1} \mathrm{H}\right)$ and $100 \mathrm{MHz}\left({ }^{13} \mathrm{C}\right)$, a Varian MERCURY-400 operating at $400 \mathrm{MHz}\left({ }^{1} \mathrm{H}\right)$ and $100 \mathrm{MHz}\left({ }^{13} \mathrm{C}\right)$, and a Varian SYSTEM-500 operating at $500 \mathrm{MHz}\left({ }^{1} \mathrm{H}\right)$ and $125 \mathrm{MHz}\left({ }^{13} \mathrm{C}\right)$. The assignments were performed by means of different standard homonuclear and heteronuclear correlation experiments (gradient heteronuclear single quantum coherence (gHSQC), gradient heteronuclear multiple bond coherence (gHMBC), and nuclear Overhauser enhancement spectroscopy (NOESY)) when required.

4-Azido-2-(2-(2-oxoimidazolidin-1-yl)ethoxy)benzo-nitrile (5a). A solution of bromoarene $4 \mathrm{a}^{30}(500 \mathrm{mg}, 1.61 \mathrm{mmol})$ and $\mathrm{NaN}_{3}$ $(1.57 \mathrm{~g}, 24.2 \mathrm{mmol})$ in anhydrous DMSO $(30 \mathrm{~mL})$ in the presence of $4 \AA$ molecular sieves, and under an argon atmosphere, was heated at $100{ }^{\circ} \mathrm{C}$ for $72 \mathrm{~h}$. The reaction was allowed to cool to room temperature and diluted with $\mathrm{H}_{2} \mathrm{O}(60 \mathrm{~mL})$, and the aqueous phase was extracted with $\mathrm{CH}_{2} \mathrm{Cl}_{2}(3 \times 50 \mathrm{~mL})$. The combined organic layers were dried $\left(\mathrm{Na}_{2} \mathrm{SO}_{4}\right)$, filtered, evaporated to dryness, and lyophilized. The residue was purified by flash column chromatography $\left(\mathrm{CH}_{2} \mathrm{Cl}_{2} / \mathrm{MeOH}, 100: 3\right)$ to give $372 \mathrm{mg}(85 \%)$ of $\mathbf{5 a}$ as a yellow solid; m.p.: $158-161{ }^{\circ} \mathrm{C}$; IR ( $\left.\mathrm{KBr}\right), \nu\left(\mathrm{cm}^{-1}\right): 3230$ (NH-st), 3090 $\left(\mathrm{C}_{\mathrm{sp}}-\mathrm{H}\right.$ st $), 2223(\mathrm{C} \equiv \mathrm{N} \mathrm{st}), 2125(\mathrm{~N}=\mathrm{N}=\mathrm{N}$ st $), 1702(\mathrm{C}=\mathrm{O}$ st $)$; ${ }^{1} \mathrm{H} \mathrm{NMR}\left(\mathrm{CDCl}_{3}, 300 \mathrm{MHz}\right) \delta(\mathrm{ppm}): 7.53(\mathrm{~d}, J=8.3 \mathrm{~Hz}, 1 \mathrm{H}, \mathrm{Ar})$, $6.70(\mathrm{dd}, J=8.3,2.0 \mathrm{~Hz}, 1 \mathrm{H}, \mathrm{Ar}), 6.53(\mathrm{~d}, J=1.8 \mathrm{~Hz}, 1 \mathrm{H}, \mathrm{Ar}), 4.71$ (bs, $1 \mathrm{H}, \mathrm{NHCON}), 4.20\left(\mathrm{t}, J=4.7 \mathrm{~Hz}, 2 \mathrm{H}, \mathrm{OCH}_{2}\right), 3.81-3.76(\mathrm{~m}$, $\left.2 \mathrm{H}, \mathrm{CH}_{2} \mathrm{CH}_{2} \mathrm{NHCON}\right), 3.64\left(\mathrm{t}, J=4.9 \mathrm{~Hz}, 2 \mathrm{H}, \mathrm{OCH}_{2} \underline{\mathrm{C}}_{2}\right), 3.44(\mathrm{t}$, $\left.J=8.1 \mathrm{~Hz}, 2 \mathrm{H}, \mathrm{CH}_{2} \mathrm{CH}_{2} \mathrm{NHCON}\right) ;{ }^{13} \mathrm{C} \mathrm{NMR}\left(\mathrm{CDCl}_{3}, 75 \mathrm{MHz}\right) \delta$ (ppm): $162.8(\mathrm{NHCON}), 161.8\left(\mathrm{OC}_{\mathrm{Ar}}\right), 146.8\left(\mathrm{C}_{\mathrm{Ar}}\right), 134.9\left(\mathrm{CH}_{\mathrm{Ar}}\right)$, $116.2(\mathrm{CN}), 111.8\left(\mathrm{CH}_{\mathrm{Ar}}\right), 103.2\left(\mathrm{CH}_{\mathrm{Ar}}\right), 98.3\left(\mathrm{C}_{\mathrm{Ar}}\right), 69.4\left(\mathrm{OCH}_{2}\right)$, $47.8\left(\mathrm{CH}_{2} \mathrm{CH}_{2} \mathrm{NHCON}\right), \quad 43.2\left(\mathrm{OCH}_{2} \underline{\mathrm{C}} \mathrm{H}_{2}\right), \quad 38.6$ $\left(\mathrm{CH}_{2} \mathrm{CH}_{2} \mathrm{NHCON}\right.$ ); MS (ESI, positive mode) $\mathrm{m} / z: 567.2[2 \mathrm{M}+$ $\mathrm{Na}]^{+}, 295.0[\mathrm{M}+\mathrm{Na}]^{+}, 273.0[\mathrm{M}+\mathrm{H}]^{+}$. $\mathrm{NaN}_{3}$ may be toxic and explosive. Thus, for safety precautions, a polycarbonate safety screen in a properly functioning fume hood was always used to perform this reaction.

Benzyl-4-(1-(4-cyano-3-((1-(2-oxoimidazolidin-1-yl)ethoxy)phenyl)-1H-1,2,3-triazol-4-yl)butyl)carbamate (8). To a solution of azide $5 \mathrm{a}$ (450 mg, $1.65 \mathrm{mmol})$, commercially available benzyl-5hexynylcarbamate $(523 \mathrm{mg}, 2.15 \mathrm{mmol})$, and $\mathrm{CuSO}_{4} \cdot 5 \mathrm{H}_{2} \mathrm{O}(42 \mathrm{mg}$, $0.17 \mathrm{mmol})$ in EtOH $(25 \mathrm{~mL})$ were added sodium ascorbate $(131$ $\mathrm{mg}, 0.66 \mathrm{mmol})$ and $\mathrm{H}_{2} \mathrm{O}(25 \mathrm{~mL})$. The reaction mixture was stirred at room temperature in the dark overnight. The mixture was evaporated to dryness, and the residue dissolved in $\mathrm{CH}_{2} \mathrm{Cl}_{2}(50 \mathrm{~mL})$ was washed with $\mathrm{H}_{2} \mathrm{O}(3 \times 50 \mathrm{~mL})$, dryed $\left(\mathrm{Na}_{2} \mathrm{SO}_{4}\right)$, filtered, and evaporated under reduced pressure. The residue was purified by flash column chromatography $\left(\mathrm{CH}_{2} \mathrm{Cl}_{2} / \mathrm{MeOH}, 100: 3\right)$ to provide 8 (573 $\mathrm{mg}, 69 \%)$ as a colorless oil. ${ }^{1} \mathrm{H}$ NMR $\left(\mathrm{CDCl}_{3}, 400 \mathrm{MHz}\right) \delta(\mathrm{ppm})$ : 7.86 (s, 1H, Ar), 7.61 (d, J = 8.3 Hz, 1H, Ar), 7.49 (s, 1H, Ar), 7.34 $(\mathrm{d}, J=7.1 \mathrm{~Hz}, 1 \mathrm{H}, \mathrm{Ar}), 7.32-7.17(\mathrm{~m}, 5 \mathrm{H}, \mathrm{Ar}), 5.05(\mathrm{bs}, 1 \mathrm{H}$, $\mathrm{NHCbz}$ ), 5.02 (s, 2H, NHCOOC$\underline{\mathrm{H}}_{2}$ ), 4.68 (bs, $\left.1 \mathrm{H}, \mathrm{NHCON}\right), 4.26$ $\left(\mathrm{t}, J=5.2 \mathrm{~Hz}, 2 \mathrm{H}, \mathrm{OCH}_{2}\right), 3.66(\mathrm{t}, J=7.9 \mathrm{~Hz}, 2 \mathrm{H}$, $\left.\mathrm{C}_{2} \mathrm{CH}_{2} \mathrm{NHCON}\right), 3.57\left(\mathrm{t}, J=5.2 \mathrm{~Hz}, 2 \mathrm{H}, \mathrm{OCH}_{2} \mathrm{CH}_{2}\right), 3.33(\mathrm{t}, J$ $\left.=8.3 \mathrm{~Hz}, 2 \mathrm{H}, \mathrm{CH}_{2} \mathrm{CH}_{2} \mathrm{NHCON}\right), 3.18(\mathrm{q}, J=6.7 \mathrm{~Hz}, 2 \mathrm{H}$, $\mathrm{C}_{2}{ }_{2} \mathrm{NHCbz}$ ), $2.76\left(\mathrm{t}, J=7.3 \mathrm{~Hz}, 2 \mathrm{H}, \mathrm{TrizCH}_{2}\right.$ ), 1.71 (quin, $J=7.4$ $\mathrm{Hz}, 2 \mathrm{H}, \mathrm{TrizCH}_{2} \underline{\mathrm{C}}_{2}$ ), 1.52 (quin, $J=7.2 \mathrm{~Hz}, 2 \mathrm{H}$, $\left.\mathrm{CH}_{2} \mathrm{CH}_{2} \mathrm{NHCbz}\right) ;{ }^{13} \mathrm{C} \mathrm{NMR}\left(\mathrm{CDCl}_{3}, 75 \mathrm{MHz}\right) \delta(\mathrm{ppm}): 162.8$ $(\mathrm{NHCON}), 161.5\left(\mathrm{OC}_{\mathrm{Ar}}\right), 156.6(\mathrm{NHCOO}), 149.2\left(\mathrm{C}_{\mathrm{Ar}}\right), 141.5$ $\left(\mathrm{C}_{\mathrm{Ar}}\right), 136.6\left(\mathrm{CH}_{\mathrm{Ar}}\right), 135.1\left(\mathrm{CH}_{\mathrm{Ar}}\right), 128.6\left(\mathrm{CH}_{\mathrm{Ar}}\right), 128.2\left(\mathrm{CH}_{\mathrm{Ar}}\right)$, $119.1\left(\mathrm{CH}_{\mathrm{Ar}}\right), 115.7(\mathrm{CN}), 112.1\left(\mathrm{CH}_{\mathrm{Ar}}\right), 104.1\left(\mathrm{CH}_{\mathrm{Ar}}\right), 101.5\left(\mathrm{C}_{\mathrm{Ar}}\right)$, $69.0\left(\mathrm{OCH}_{2}\right), 66.7\left(\mathrm{NHCOOCH}_{2}\right), 47.3\left(\mathrm{CH}_{2} \mathrm{CH}_{2} \mathrm{NHCON}\right), 42.8$ 
$\left(\mathrm{OCH}_{2} \underline{\mathrm{CH}}_{2}\right), 40.8\left(\mathrm{CH}_{2} \mathrm{NHCbz}\right), 38.5\left(\mathrm{CH}_{2} \underline{\mathrm{CH}}_{2} \mathrm{NHCON}\right), 29.4$ $\left(\mathrm{CH}_{2} \mathrm{CH}_{2} \mathrm{NHCbz}\right), 26.1\left(\operatorname{TrizCH}_{2} \underline{\mathrm{CH}}_{2}\right), 25.1\left(\mathrm{Triz}_{\mathrm{CH}}\right) ; \mathrm{HRMS}$ (ES, positive mode) $\mathrm{m} / z$ : calcd for $\mathrm{C}_{26} \mathrm{H}_{29} \mathrm{~N}_{7} \mathrm{O}_{4}$ 503.2281; found 503.2279 ( $-0.33 \mathrm{ppm})$.

Benzyl-4-(1-(4-carbamothioyl-3-((1-(2-oxoimidazolidin-1-yl)ethoxy)phenyl)-1H-1,2,3-triazol-4-yl)butyl)carbamate (9). To a solution of benzonitrile $8(400 \mathrm{mg}, 0.79 \mathrm{mmol})$ in DMF $(25 \mathrm{~mL})$, $20 \%$ aq $\left(\mathrm{NH}_{4}\right)_{2} \mathrm{~S}(3.78 \mathrm{~mL}, 55.6 \mathrm{mmol})$ was added and then heated to $80{ }^{\circ} \mathrm{C}$ for $4 \mathrm{~h}$. The reaction mixture was allowed to cool to room temperature, and then, $\mathrm{CH}_{2} \mathrm{Cl}_{2}(50 \mathrm{~mL})$ was added. The mixture was successively washed with $\mathrm{HCl} 0.1 \mathrm{~N}(2 \times 50 \mathrm{~mL}), \mathrm{H}_{2} \mathrm{O}(1 \times 50 \mathrm{~mL})$, and brine $(1 \times 50 \mathrm{~mL})$. The organic layers were dried $\left(\mathrm{Na}_{2} \mathrm{SO}_{4}\right)$, filtered, and evaporated to dryness. The crude was purified by flash column chromatography $\left(\mathrm{CH}_{2} \mathrm{Cl}_{2} / \mathrm{MeOH}, 100: 5\right)$ to give 9 (354 mg, $74 \%)$ as a yellow oil. ${ }^{1} \mathrm{H} \mathrm{NMR}\left(\mathrm{CDCl}_{3}, 400 \mathrm{MHz}\right) \delta(\mathrm{ppm}): 9.63(\mathrm{bs}$, $\left.1 \mathrm{H}, \mathrm{SCNH}_{2}\right), 9.50\left(\mathrm{bs}, 1 \mathrm{H}, \mathrm{SCNH}_{2}\right), 8.71(\mathrm{~d}, J=8.7 \mathrm{~Hz}, 1 \mathrm{H}, \mathrm{Ar})$, $7.78(\mathrm{~s}, 1 \mathrm{H}, \mathrm{Ar}), 7.45$ (d, $J=2.0 \mathrm{~Hz}, 1 \mathrm{H}, \mathrm{Ar}), 7.36-7.17(\mathrm{~m}, 5 \mathrm{H}, \mathrm{Ar})$, 7.10 (dd, $J=8.7,2.0 \mathrm{~Hz}, 1 \mathrm{H}, \mathrm{Ar}), 5.96$ (bs, $1 \mathrm{H}, \mathrm{NHCbz}), 5.02(\mathrm{~s}, 2 \mathrm{H}$, $\left.\mathrm{NHCOOC}_{2}\right), 4.98(\mathrm{bs}, 1 \mathrm{H}, \mathrm{NHCON}), 4.16(\mathrm{t}, J=4.4 \mathrm{~Hz}, 2 \mathrm{H}$, $\left.\mathrm{OCH}_{2}\right), 3.64\left(\mathrm{t}, J=4.4 \mathrm{~Hz}, 2 \mathrm{H}, \mathrm{OCH}_{2} \mathrm{CH}_{2}\right), 3.50(\mathrm{dd}, J=9.7,6.7$ $\left.\mathrm{Hz}, 2 \mathrm{H}, \quad \mathrm{CH}_{2} \mathrm{CH}_{2} \mathrm{NHCON}\right), 3.40(\mathrm{dd}, J=9.1,6.2 \mathrm{~Hz}, 2 \mathrm{H}$, $\mathrm{CH}_{2} \underline{\mathrm{C}}_{2} \mathrm{NHCON}$ ), $3.17\left(\mathrm{q}, J=6.7 \mathrm{~Hz}, 2 \mathrm{H}, \mathrm{C}_{2} \mathrm{NHCbz}\right), 2.73(\mathrm{t}$, $J=7.5 \mathrm{~Hz}, 2 \mathrm{H}$, TrizCH${ }_{2}$ ), 1.70 (quin, $J=7.5 \mathrm{~Hz}, 2 \mathrm{H}, \operatorname{TrizCH}_{2} \mathrm{C}_{2}$ ), 1.53 (quin, $\left.J=7.5 \mathrm{~Hz}, 2 \mathrm{H}, \mathrm{CH}_{2} \mathrm{CH}_{2} \mathrm{NHCbz}\right) ;{ }^{13} \mathrm{C} \mathrm{NMR}\left(\mathrm{CDCl}_{3}, 75\right.$ $\mathrm{MHz}) \delta(\mathrm{ppm}): 196.5\left(\mathrm{SCNH}_{2}\right), 163.5$ (NHCON), 156.3 (NHCOO), $149.1\left(\mathrm{C}_{\mathrm{Ar}}\right), 140.3\left(\mathrm{C}_{\mathrm{Ar}}\right), 138.4\left(\mathrm{CH}_{\mathrm{Ar}}\right), 136.7\left(\mathrm{CH}_{\mathrm{Ar}}\right)$, $128.7\left(\mathrm{CH}_{\mathrm{Ar}}\right), 128.2\left(\mathrm{CH}_{\mathrm{Ar}}\right), 125.1\left(\mathrm{C}_{\mathrm{Ar}}\right), 119.1\left(\mathrm{CH}_{\mathrm{Ar}}\right), 111.3$ $\left(\mathrm{CH}_{\mathrm{Ar}}\right), 104.0\left(\mathrm{CH}_{\mathrm{Ar}}\right), 66.8\left(\mathrm{OCH}_{2}\right), 66.6\left(\mathrm{NHCOOCH}_{2}\right), 45.4$ $\left(\mathrm{CH}_{2} \mathrm{CH}_{2} \mathrm{NHCON}\right), 43.2\left(\mathrm{OCH}_{2} \mathrm{CH}_{2}\right), 40.9\left(\mathrm{CH}_{2} \mathrm{NHCbz}\right), 38.3$ $\left(\mathrm{CH}_{2} \underline{\mathrm{CH}}_{2} \mathrm{NHCON}\right), 29.8\left(\underline{\mathrm{CH}}_{2} \mathrm{CH}_{2} \mathrm{NHCbz}\right), 26.4\left(\mathrm{TrizCH}_{2} \mathrm{CH}_{2}\right)$, $25.3\left(\right.$ Triz $\left.\mathrm{CH}_{2}\right)$; MS (ESI, positive mode) $\mathrm{m} / z: 538.3[\mathrm{M}+\mathrm{H}]^{+}$.

General Procedure for the Synthesis of Thiazoles $11 a-c$ by Hantzsch Cyclization. A solution of thioamide 9 (1 equiv) in ${ }^{i} \mathrm{PrOH}$ $(15 \mathrm{~mL})$ was treated with the appropriated $\alpha$-haloketone $(10 \mathrm{a}-\mathrm{c})(1$ equiv). The reaction mixture was stirred at $70{ }^{\circ} \mathrm{C}$ for $3-6 \mathrm{~h}$ in a pressure flask, and then, it was allowed to cool to room temperature and concentrated to dryness under reduced pressure. The residue was purified by flash column chromatography or CCTLC on a Chromatotron (eluents are specified in each case).

Benzyl-(4-(1-(3-(2-(2-oxoimidazolidin-1-yl)ethoxy)-4-(4-phenethylthiazol-2-yl)phenyl)-1H-1,2,3-triazol-4-yl)butyl)carbamate (11a). Following the general procedure, thioamide 9 (100 mg, 0.19 $\mathrm{mmol}$ ) and the commercially available 1-bromo-4-phenylbutan-2-one (10a $42 \mathrm{mg}, 0.19 \mathrm{mmol})$ in ${ }^{i} \mathrm{PrOH}(15 \mathrm{~mL})$ reacted at $70{ }^{\circ} \mathrm{C}$ for $4 \mathrm{~h}$. After the workup, the residue was purified by CCTLC on the Chromatotron $\left(\mathrm{CH}_{2} \mathrm{Cl}_{2} / \mathrm{MeOH}, 100: 3\right)$ to yield $108 \mathrm{mg}$ (87\%) of 11a as a colorless oil. ${ }^{1} \mathrm{H}$ NMR $\left(\mathrm{CDCl}_{3}, 400 \mathrm{MHz}\right) \delta(\mathrm{ppm}): 8.46(\mathrm{~d}$, $J=8.5 \mathrm{~Hz}, 1 \mathrm{H}, \mathrm{Ar}), 7.81(\mathrm{~s}, 1 \mathrm{H}, \mathrm{Ar}), 7.51(\mathrm{~d}, J=2.0 \mathrm{~Hz}, 1 \mathrm{H}, \mathrm{Ar})$, $7.38-7.06(\mathrm{~m}, 11 \mathrm{H}, \mathrm{Ar}), 6.86(\mathrm{~s}, 1 \mathrm{H}, \mathrm{Ar}), 5.06(\mathrm{t}, J=6.0 \mathrm{~Hz}, 1 \mathrm{H}$, $\mathrm{NHCbz}), 5.01\left(\mathrm{~s}, 2 \mathrm{H}, \mathrm{NHCOOC}_{2}\right), 4.34(\mathrm{t}, J=5.7 \mathrm{~Hz}, 2 \mathrm{H}$, $\left.\mathrm{OCH}_{2}\right), 3.69\left(\mathrm{t}, J=5.7 \mathrm{~Hz}, 2 \mathrm{H}, \mathrm{OCH}_{2} \underline{\mathrm{H}}_{2}\right), 3.50(\mathrm{dd}, J=9.0,6.7$ $\left.\mathrm{Hz}, 2 \mathrm{H}, \quad \mathrm{CH}_{2} \mathrm{CH}_{2} \mathrm{NHCON}\right), 3.26(\mathrm{t}, J=7.9 \mathrm{~Hz}, 2 \mathrm{H}$, $\mathrm{CH}_{2} \underline{\mathrm{C}}_{2} \mathrm{NHCON}$ ), 3.18 (q, $J=7.4 \mathrm{~Hz}, 2 \mathrm{H}, \mathrm{C}_{2} \mathrm{NHCbz}$ ), 3.12$2.97\left(\mathrm{~m}, 4 \mathrm{H}, \mathrm{C}_{2} \mathrm{CH}_{2} \mathrm{Ph}\right), 2.76\left(\mathrm{t}, J=7.4 \mathrm{~Hz}, 2 \mathrm{H}, \mathrm{TrizCH}_{2}\right), 1.71$ (quin, $J=7.4 \mathrm{~Hz}, 2 \mathrm{H}$, TrizCH $\mathrm{CH}_{2}$ ), 1.59 (quin, $J=7.1 \mathrm{~Hz}, 2 \mathrm{H}$, $\left.\mathrm{C}_{2} \mathrm{CH}_{2} \mathrm{NHCbz}\right) ;{ }^{13} \mathrm{C}$ NMR $\left(\mathrm{CDCl}_{3}, 75 \mathrm{MHz}\right) \delta(\mathrm{ppm}): 162.8$ $(\mathrm{NHCON}), 160.3\left(\mathrm{OC}_{\mathrm{Ar}}\right), 156.6\left(\mathrm{C}_{\mathrm{Ar}}\right), 156.0\left(\mathrm{C}_{\mathrm{Ar}}\right), 155.9\left(\mathrm{C}_{\mathrm{Ar}}\right)$, $148.7\left(\mathrm{C}_{\mathrm{Ar}}\right), 141.7\left(\mathrm{C}_{\mathrm{Ar}}\right), 138.3\left(\mathrm{C}_{\mathrm{Ar}}\right), 136.7\left(\mathrm{C}_{\mathrm{Ar}}\right), 130.0\left(\mathrm{CH}_{\mathrm{Ar}}\right)$, $128.6\left(\mathrm{CH}_{\mathrm{Ar}}\right), 128.6\left(\mathrm{CH}_{\mathrm{Ar}}\right), 128.4\left(\mathrm{CH}_{\mathrm{Ar}}\right), 128.2\left(\mathrm{CH}_{\mathrm{Ar}}\right), 126.1$ $\left(\mathrm{CH}_{\mathrm{Ar}}\right), 122.7\left(\mathrm{C}_{\mathrm{Ar}}\right), 119.1\left(\mathrm{CH}_{\mathrm{Ar}}\right), 115.1\left(\mathrm{CH}_{\mathrm{Ar}}\right), 112.4\left(\mathrm{CH}_{\mathrm{Ar}}\right)$, $104.5\left(\mathrm{CH}_{\mathrm{Ar}}\right), 67.8\left(\mathrm{OCH}_{2}\right), 66.7\left(\mathrm{NHCOOCH}_{2}\right), 46.4$ $\left(\mathrm{CH}_{2} \mathrm{CH}_{2} \mathrm{NHCON}\right), 43.0\left(\mathrm{OCH}_{2} \mathrm{CH}_{2}\right), 40.8\left(\mathrm{CH}_{2} \mathrm{NHCbz}\right), 38.4$ $\left(\mathrm{CH}_{2} \mathrm{CH}_{2} \mathrm{NHCON}\right), 35.6\left(\mathrm{CH}_{2} \mathrm{CH}_{2} \mathrm{Ph}\right), 33.4\left(\mathrm{CH}_{2} \mathrm{CH}_{2} \mathrm{Ph}\right), 29.4$ $\left(\mathrm{CH}_{2} \mathrm{CH}_{2} \mathrm{NHCbz}\right), 26.4\left(\operatorname{TrizCH}_{2} \mathrm{CH}_{2}\right), 25.2\left(\mathrm{Triz}_{2} \mathrm{CH}_{2}\right) ; \mathrm{HRMS}$ (ES, positive mode) $\mathrm{m} / z$ : calcd for $\mathrm{C}_{36} \mathrm{H}_{39} \mathrm{~N}_{7} \mathrm{O}_{4} \mathrm{~S}$ 665.2784; found 665.2791 (1.00 ppm).

Benzyl-(E)-(4-(1-(4-(4-(2-(naphthalen-2-yl)vinyl)thiazol-2-yl)-3(2-(2-oxoimidazolidin-1-yl)ethoxy)phenyl)-1H-1,2,3-triazol-4-yl)butyl)carbamate (11b). According to the general procedure, thioamide $9(520 \mathrm{mg}, 0.97 \mathrm{mmol})$ and $\alpha$-bromoketone $\mathbf{1 0 b}^{30}(267$ $\mathrm{mg}, 0.97 \mathrm{mmol}$ ) were reacted at $70{ }^{\circ} \mathrm{C}$ for $5 \mathrm{~h}$ in ${ }^{i} \mathrm{PrOH}$. After the workup, the residue was purified by flash column chromatography $\left(\mathrm{CH}_{2} \mathrm{Cl}_{2} / \mathrm{MeOH}, 100: 4\right)$ to give $\mathbf{1 1 b}(365 \mathrm{mg}, 51 \%)$ as a yellow oil. ${ }^{1} \mathrm{H} \mathrm{NMR}\left(\mathrm{CDCl}_{3}, 400 \mathrm{MHz}\right) \delta(\mathrm{ppm}): 8.61(\mathrm{~d}, J=8.5 \mathrm{~Hz}, 1 \mathrm{H}, \mathrm{Ar})$, 7.90-7.64 (m, 7H, Ar, ThiazCH=C $(\mathrm{m}, 3 \mathrm{H}, \mathrm{Ar}), 7.30-7.14(\mathrm{~m}, 7 \mathrm{H}, \mathrm{Ar}, \mathrm{Thiaz} \mathrm{H}=\mathrm{CH}), 5.03(\mathrm{~s}, 2 \mathrm{H}$, $\mathrm{NHCOOC}_{2}$ ), 4.97 (bs, $\left.1 \mathrm{H}, \mathrm{NHCON}\right), 4.48$ (bs, $\left.1 \mathrm{H}, \mathrm{NHCbz}\right), 4.39$ $\left(\mathrm{t}, J=5.7 \mathrm{~Hz}, 2 \mathrm{H}, \mathrm{OCH}_{2}\right), 3.73\left(\mathrm{t}, J=5.7 \mathrm{~Hz}, 2 \mathrm{H}, \mathrm{OCH}_{2} \mathrm{CH}_{2}\right), 3.52$ (dd, $\left.J=9.0,6.6 \mathrm{~Hz}, 2 \mathrm{H}, \mathrm{CH}_{2} \mathrm{CH}_{2} \mathrm{NHCON}\right), 3.28(\mathrm{t}, J=7.9 \mathrm{~Hz}, 2 \mathrm{H}$, $\left.\mathrm{CH}_{2} \underline{\mathrm{C}}_{2} \mathrm{NHCON}\right), 3.20\left(\mathrm{q}, J=6.7 \mathrm{~Hz}, 2 \mathrm{H}, \mathrm{C}_{2} \mathrm{NHCbz}\right), 2.78(\mathrm{t}, J$ $=7.3 \mathrm{~Hz}, 2 \mathrm{H}$, TrizCH${ }_{2}$ ), 1.74 (quin, $J=7.5 \mathrm{~Hz}, 2 \mathrm{H}$, TrizCH $\mathrm{CH}_{2}$ ), 1.59-1.51 (m, 2H, $\left.\underline{\mathrm{C}}_{2} \mathrm{CH}_{2} \mathrm{NHCbz}\right) ;{ }^{13} \mathrm{C} \mathrm{NMR}\left(\mathrm{CDCl}_{3}, 75 \mathrm{MHz}\right) \delta$ $(\mathrm{ppm}): 162.7(\mathrm{NHCON}), 161.0\left(\mathrm{OC}_{\mathrm{Ar}}\right), 156.6\left(\mathrm{C}_{\mathrm{Ar}}\right), 156.2\left(\mathrm{C}_{\mathrm{Ar}}\right)$, $153.5\left(\mathrm{C}_{\mathrm{Ar}}\right), 148.8\left(\mathrm{C}_{\mathrm{Ar}}\right), 138.6\left(\mathrm{C}_{\mathrm{Ar}}\right), 136.7\left(\mathrm{C}_{\mathrm{Ar}}\right), 134.7\left(\mathrm{CH}_{\mathrm{Ar}}\right)$, $133.8\left(\mathrm{C}_{\mathrm{Ar}}\right), 133.3\left(\mathrm{C}_{\mathrm{Ar}}\right), 131.5\left(\mathrm{CH}_{\mathrm{Ar}}\right), 130.3\left(\mathrm{CH}_{\mathrm{Ar}}\right), 128.7\left(\mathrm{CH}_{\mathrm{Ar}}\right)$, $128.4\left(\mathrm{CH}_{\mathrm{Ar}}\right), 128.3\left(\mathrm{CH}_{\mathrm{Ar}}\right), 128.2\left(\mathrm{CH}_{\mathrm{Ar}}\right), 127.8\left(\mathrm{CH}_{\mathrm{Ar}}\right), 127.2$ $\left(\mathrm{C}_{\mathrm{Ar}}\right), 126.5\left(\mathrm{CH}_{\mathrm{Ar}}\right), 126.1\left(\mathrm{CH}_{\mathrm{Ar}}\right), 123.6\left(\mathrm{CH}_{\mathrm{Ar}}\right), 121.8\left(\mathrm{CH}_{\mathrm{Ar}}\right)$, $119.2\left(\mathrm{CH}_{\mathrm{Ar}}\right), 117.1\left(\mathrm{CH}_{\mathrm{Ar}}\right), 112.5\left(\mathrm{CH}_{\mathrm{Ar}}\right), 104.5\left(\mathrm{CH}_{\mathrm{Ar}}\right), 67.7$ $\left(\mathrm{OCH}_{2}\right), 66.8\left(\mathrm{NHCOOCH}_{2}\right), 46.4\left(\mathrm{CH}_{2} \mathrm{CH}_{2} \mathrm{NHCON}\right), 43.0$ $\left(\mathrm{OCH}_{2} \mathrm{CH}_{2}\right), 40.9\left(\mathrm{CH}_{2} \mathrm{NHCbz}\right), 38.4\left(\mathrm{CH}_{2} \mathrm{CH}_{2} \mathrm{NHCON}\right), 29.5$ $\left(\underline{\mathrm{CH}}_{2} \mathrm{CH}_{2} \mathrm{NHCbz}\right), 26.4\left(\mathrm{TrizCH}_{2} \underline{\mathrm{CH}}_{2}\right), 25.2\left(\mathrm{Triz}_{\mathrm{CH}}\right)$; HRMS (ES, positive mode) $\mathrm{m} / z$ : calcd for $\mathrm{C}_{40} \mathrm{H}_{39} \mathrm{~N}_{7} \mathrm{O}_{4} \mathrm{~S}$ 713.2784; found $713.2779(-0.72 \mathrm{ppm})$.

Benzyl-(E)-(4-(1-(4-(4-(2-([1, 1'-biphenyl]-4-yl)vinyl) thiazol-2-yl)3-(2-(2-oxoimidazolidin-1-yl)ethoxy)phenyl)-1H-1,2,3-triazol-4-yl)butyl)carbamate (11c). Following the general Hantzsch synthesis, 9 (200 mg, $0.37 \mathrm{mmol}$ ) reacted with $\alpha$-bromoketone $10 \mathrm{c}^{30}$ (112 mg, $0.37 \mathrm{mmol}$ ) for $5 \mathrm{~h}$. After the workup, the residue was purified by flash column chromatography $\left(\mathrm{CH}_{2} \mathrm{Cl}_{2} / \mathrm{MeOH}, 100: 3\right)$ to give 174 $\mathrm{mg}(63 \%)$ of $11 \mathrm{c}$ as a colorless oil. ${ }^{1} \mathrm{H}$ NMR $\left(\mathrm{CDCl}_{3}, 400 \mathrm{MHz}\right) \delta$ (ppm): 8.57 (d, $J=8.5 \mathrm{~Hz}, 1 \mathrm{H}, \mathrm{Ar}), 7.81(\mathrm{~s}, 1 \mathrm{H}, \mathrm{Ar}), 7.61-7.45$ (m, $8 \mathrm{H}, \mathrm{Ar}$, ThiazCH $=\mathrm{CH}), 7.40-7.31(\mathrm{~m}, 3 \mathrm{H}, \mathrm{Ar}), 7.31-7.16(\mathrm{~m}, 7 \mathrm{H}$, $\mathrm{Ar}), 7.12(\mathrm{~d}, J=16.0 \mathrm{~Hz}, 1 \mathrm{H}, \mathrm{Thiaz} \mathrm{CH}=\mathrm{CH}), 5.02(\mathrm{~s}, 2 \mathrm{H}$, $\left.\mathrm{NHCOOC}_{2}\right), 4.68(\mathrm{bs}, 1 \mathrm{H}, \mathrm{NHCON}), 4.36(\mathrm{t}, J=5.7 \mathrm{~Hz}, 2 \mathrm{H}$, $\left.\mathrm{OCH}_{2}\right), 3.70\left(\mathrm{t}, J=5.8 \mathrm{~Hz}, 2 \mathrm{H}, \mathrm{OCH}_{2} \mathrm{CH}_{2}\right), 3.50(\mathrm{dd}, J=9.0,6.7$ $\left.\mathrm{Hz}, \quad 2 \mathrm{H}, \quad \mathrm{CH}_{2} \mathrm{CH}_{2} \mathrm{NHCON}\right), 3.26(\mathrm{t}, J=7.9 \mathrm{~Hz}, 2 \mathrm{H}$, $\mathrm{CH}_{2} \underline{\mathrm{C}}_{2} \mathrm{NHCON}$ ), 3.16 (q, $J=6.6 \mathrm{~Hz}, 2 \mathrm{H}, \mathrm{C}_{2} \mathrm{NHCbz}_{2}, 2.76$ (t, $J=7.3 \mathrm{~Hz}, 2 \mathrm{H}$, Triz $\mathrm{CH}_{2}$ ), 1.75 (quin, $J=7.5 \mathrm{~Hz}, 2 \mathrm{H}, \operatorname{TrizCH}_{2} \mathrm{C}_{2}$ ), 1.55 (quin, $\left.J=7.3 \mathrm{~Hz}, 2 \mathrm{H}, \mathrm{C}_{2} \mathrm{CH}_{2} \mathrm{NHCbz}\right) ;{ }^{13} \mathrm{C} \mathrm{NMR}\left(\mathrm{CDCl}_{3}, 75\right.$ $\mathrm{MHz}) \delta(\mathrm{ppm}): 162.7(\mathrm{NHCON}), 160.9\left(\mathrm{OC}_{\mathrm{Ar}}\right), 156.6\left(\mathrm{C}_{\mathrm{Ar}}\right), 156.2$ $\left(\mathrm{C}_{\mathrm{Ar}}\right), 153.4\left(\mathrm{C}_{\mathrm{Ar}}\right), 148.8\left(\mathrm{C}_{\mathrm{Ar}}\right), 140.7\left(\mathrm{C}_{\mathrm{Ar}}\right), 140.6\left(\mathrm{C}_{\mathrm{Ar}}\right), 138.6$ $\left(\mathrm{CH}_{\mathrm{Ar}}\right), 136.7\left(\mathrm{C}_{\mathrm{Ar}}\right), 136.2\left(\mathrm{CH}_{\mathrm{Ar}}\right), 130.9\left(\mathrm{CH}_{\mathrm{Ar}}\right), 130.3\left(\mathrm{CH}_{\mathrm{Ar}}\right)$, $128.9\left(\mathrm{CH}_{\mathrm{Ar}}\right), 128.6\left(\mathrm{CH}_{\mathrm{Ar}}\right), 128.3\left(\mathrm{CH}_{\mathrm{Ar}}\right), 127.5\left(\mathrm{CH}_{\mathrm{Ar}}\right), 127.0$ $\left(\mathrm{CH}_{\mathrm{Ar}}\right), 122.4\left(\mathrm{C}_{\mathrm{Ar}}\right), 121.5\left(\mathrm{CH}_{\mathrm{Ar}}\right), 119.1\left(\mathrm{CH}_{\mathrm{Ar}}\right), 117.4\left(\mathrm{CH}_{\mathrm{Ar}}\right)$, $112.4\left(\mathrm{CH}_{\mathrm{Ar}}\right), 104.4\left(\mathrm{CH}_{\mathrm{Ar}}\right), 67.7\left(\mathrm{OCH}_{2}\right), 66.8\left(\mathrm{NHCOOCH}_{2}\right)$, $46.4\left(\mathrm{CH}_{2} \mathrm{CH}_{2} \mathrm{NHCON}\right), 42.9\left(\mathrm{OCH}_{2} \mathrm{CH}_{2}\right), 40.9\left(\mathrm{CH}_{2} \mathrm{NHCbz}\right)$, $38.4\left(\mathrm{CH}_{2} \underline{\mathrm{C}} \mathrm{H}_{2} \mathrm{NHCON}\right), 29.4\left(\mathrm{C}_{2} \mathrm{CH}_{2} \mathrm{NHCbz}\right), 26.4$ (TrizCH $\mathrm{CH}_{2}$ ), $25.2\left(\right.$ Triz $\left.\mathrm{CH}_{2}\right)$; HRMS (ES, positive mode) $\mathrm{m} / z$ : calcd for $\mathrm{C}_{42} \mathrm{H}_{41} \mathrm{~N}_{7} \mathrm{O}_{4} \mathrm{~S} 739.2941$; found 739.2972 (4.21 ppm).

General Procedure for $\mathrm{N}$-Cbz Deprotection. A solution of the corresponding Cbz-protected compound (1 equiv) in a 1:1 mixture of $\mathrm{THF} / \mathrm{MeOH}(20 \mathrm{~mL})$ containing Pd/C (10\%) $(20 \% \mathrm{w} / \mathrm{w})$ and TFA $(0.5-1.5 \mathrm{~mL})$ was hydrogenated at room temperature for $2 \mathrm{~h}$ under atmospheric pressure using a balloon filled with hydrogen gas (three cycles of vacuum + hydrogen). The $\mathrm{Pd} / \mathrm{C}$ was filtered through Whatman poly(tetrafluoroethylene) (PTFE) filter paper, and the solvent was removed under reduced pressure and co-evaporated with mixtures of $\mathrm{CH}_{2} \mathrm{Cl}_{2} / \mathrm{MeOH}(5 \times 10 \mathrm{~mL})$. The residue was purified by HPFC on an SP1 Isolera Biotage using reverse-phase columns (from $0 \%$ of $\mathrm{CH}_{3} \mathrm{CN}$ to $100 \%$ of $\mathrm{CH}_{3} \mathrm{CN}$ in $45 \mathrm{~min}$ ) to afford to give the final deprotected compounds as trifluoroacetate salts.

1-(2-(5-(4-(4-Ammoniumbutyl)-1H-1,2,3-triazol-1-yl)-2-(4-phenethylthiazol-2-yl)phenoxy)ethyl)imidazolidin-2-one 2,2,2-Trifluoroacetate (12a). According to the general hydrogenolysis procedure, a solution of 11a $(55 \mathrm{mg}, 0.08 \mathrm{mmol})$, in 1:1 THF/MeOH $(20 \mathrm{~mL})$ containing $\mathrm{Pd} / \mathrm{C}(10 \%)(20 \% \mathrm{w} / \mathrm{w})(18 \mathrm{mg})$ and TFA $(0.5 \mathrm{~mL})$, was hydrogenated. The residue was purified by HPFC on the SP1 Isolera Biotage using reverse-phase columns (from $0 \%$ of $\mathrm{CH}_{3} \mathrm{CN}$ to $100 \%$ of $\mathrm{CH}_{3} \mathrm{CN}$ in $\left.45 \mathrm{~min}\right)$ to afford $12 \mathrm{a}(19 \mathrm{mg}, 35 \%)$ as a colorless oil. ${ }^{1} \mathrm{H}$ NMR $\left(\mathrm{CD}_{3} \mathrm{OD}, 400 \mathrm{MHz}\right) \delta(\mathrm{ppm}): 8.47(\mathrm{~s}, 1 \mathrm{H}, \mathrm{Ar}), 8.46(\mathrm{~d}, J=8.5$ 
$\mathrm{Hz}, 1 \mathrm{H}, \mathrm{Ar}$ ), 7.70 (d, $J=2.0 \mathrm{~Hz}, 1 \mathrm{H}, \mathrm{Ar}), 7.58$ (dd, $J=8.6,2.0 \mathrm{~Hz}$, $1 \mathrm{H}, \mathrm{Ar}), 7.33-7.17(\mathrm{~m}, 5 \mathrm{H}, \mathrm{Ar}), 7.15(\mathrm{~s}, 1 \mathrm{H}, \mathrm{Ar}), 4.48(\mathrm{t}, J=5.5 \mathrm{~Hz}$, $\left.2 \mathrm{H}, \mathrm{OCH}_{2}\right), 3.74\left(\mathrm{t}, J=5.5 \mathrm{~Hz}, 2 \mathrm{H}, \mathrm{OCH}_{2} \mathrm{CH}_{2}\right), 3.60(\mathrm{dd}, J=9.3$, $\left.6.9 \mathrm{~Hz}, 2 \mathrm{H}, \mathrm{CH}_{2} \mathrm{CH}_{2} \mathrm{NHCON}\right), 3.36(\mathrm{dd}, J=9.3,6.9 \mathrm{~Hz}, 2 \mathrm{H}$, $\mathrm{CH}_{2} \mathrm{CH}_{2} \mathrm{NHCON}$ ), 3.15-3.03 (m, 4H, $\left.\underline{\mathrm{H}}_{2} \mathrm{CH}_{2} \mathrm{Ph}\right), 3.00(\mathrm{t}, J=7.4$ $\left.\mathrm{Hz}, 2 \mathrm{H}, \mathrm{CH}_{2} \mathrm{NH}_{3}^{+}\right), 2.87\left(\mathrm{t}, J=7.2 \mathrm{~Hz}, 2 \mathrm{H}, \mathrm{Triz}_{2} \mathrm{CH}_{2}\right), 1.89-1.81(\mathrm{~m}$, $2 \mathrm{H}$, TrizCH$\left.{ }_{2} \underline{\mathrm{C}}_{2}\right), 1.81-1.70\left(\mathrm{~m}, 2 \mathrm{H}, \mathrm{C}_{2} \mathrm{CH}_{2} \mathrm{NH}_{3}{ }^{+}\right) ;{ }^{13} \mathrm{C} \mathrm{NMR}$ $\left(\mathrm{CD}_{3} \mathrm{OD}, 100 \mathrm{MHz}\right) \delta(\mathrm{ppm}): 165.1(\mathrm{NHCON}), 162.0\left(\mathrm{OC}_{\mathrm{Ar}}\right)$, 157.4 $\left(\mathrm{C}_{\mathrm{Ar}}\right), 157.1\left(\mathrm{C}_{\mathrm{Ar}}\right), 149.3\left(\mathrm{C}_{\mathrm{Ar}}\right), 142.8\left(\mathrm{C}_{\mathrm{Ar}}\right), 139.7\left(\mathrm{C}_{\mathrm{Ar}}\right), 130.8$ $\left(\mathrm{CH}_{\mathrm{Ar}}\right), 129.5\left(\mathrm{CH}_{\mathrm{Ar}}\right), 129.4\left(\mathrm{CH}_{\mathrm{Ar}}\right), 127.0\left(\mathrm{CH}_{\mathrm{Ar}}\right), 123.8\left(\mathrm{C}_{\mathrm{Ar}}\right)$, $121.6\left(\mathrm{CH}_{\mathrm{Ar}}\right), 116.9\left(\mathrm{CH}_{\mathrm{Ar}}\right), 113.6\left(\mathrm{CH}_{\mathrm{Ar}}\right), 105.7\left(\mathrm{CH}_{\mathrm{Ar}}\right), 68.4$ $\left(\mathrm{OCH}_{2}\right), 47.0\left(\mathrm{CH}_{2} \mathrm{CH}_{2} \mathrm{NHCON}\right), 43.9\left(\mathrm{OCH}_{2} \mathrm{CH}_{2}\right), 40.4$ $\left(\mathrm{CH}_{2} \mathrm{NH}_{3}^{+}\right), 39.3\left(\mathrm{CH}_{2} \mathrm{CH}_{2} \mathrm{NHCON}\right), 36.7\left(\mathrm{CH}_{2} \mathrm{CH}_{2} \mathrm{Ph}\right), 34.3$ $\left(\mathrm{CH}_{2} \mathrm{CH}_{2} \mathrm{Ph}\right), 28.0\left(\mathrm{CH}_{2} \mathrm{CH}_{2} \mathrm{NH}_{3}^{+}\right), 27.1\left(\mathrm{TrizCH}_{2} \mathrm{CH}_{2}\right), 25.6$ $\left(\right.$ Triz $\left.\mathrm{CH}_{2}\right)$; HPLC (gradient A, Agilent): $R_{\mathrm{t}}=7.1 \mathrm{~min}$; HRMS (ES, positive mode) $\mathrm{m} / z$ : calcd for $\mathrm{C}_{28} \mathrm{H}_{33} \mathrm{~N}_{7} \mathrm{O}_{2} \mathrm{~S}$ 531.2416; found 531.2424 (1.35 ppm); anal. calcd for $\mathrm{C}_{28} \mathrm{H}_{33} \mathrm{~N}_{7} \mathrm{O}_{2}$ S.TFA: C, 55.80; H, 5.31; N, 15.18; S, 4.97; found: C, 55.94; H, 5.50; N, 15.08; S, 4.51.

1-(2-(5-(4-(4-Ammoniumbutyl)-1H-1,2,3-triazol-1-yl)-2-(4-(2(naphthalen-2-yl)ethyl)thiazol-2-yl)phenoxy)ethyl)imidazolidin-2one 2,2,2-Trifluoroacetate (12b). Following the deprotection procedure, compound $11 \mathrm{~b}(218 \mathrm{mg}, 0.31 \mathrm{mmol}), \mathrm{Pd} / \mathrm{C}(10 \%)$ $(20 \% \mathrm{w} / \mathrm{w})(44 \mathrm{mg})$, and TFA $(1.3 \mathrm{~mL})$ in a $1: 1$ mixture of THF/ $\mathrm{MeOH}(30 \mathrm{~mL})$ were hydrogenated. After the workup, the residue was purified by reverse phase on the Biotage to yield $51 \mathrm{mg}(24 \%)$ of 12b as a colorless oil. ${ }^{1} \mathrm{H}$ NMR (DMSO- $\left.d_{6}, 400 \mathrm{MHz}\right) \delta(\mathrm{ppm}): 8.77$ (s, $1 \mathrm{H}, \mathrm{Ar}), 8.49(\mathrm{~d}, J=8.6 \mathrm{~Hz}, 1 \mathrm{H}, \mathrm{Ar}), 7.89-7.66(\mathrm{~m}, 8 \mathrm{H}, \mathrm{Ar}$, $\left.\mathrm{NH}_{3}{ }^{+}\right), 7.52-7.34(\mathrm{~m}, 3 \mathrm{H}, \mathrm{Ar}), 7.34(\mathrm{~s}, 1 \mathrm{H}, \mathrm{Ar}), 4.47(\mathrm{t}, J=5.7 \mathrm{~Hz}$, $\left.2 \mathrm{H}, \mathrm{OCH}_{2}\right), 3.63\left(\mathrm{t}, J=5.6 \mathrm{~Hz}, 2 \mathrm{H}, \mathrm{OCH}_{2} \mathrm{CH}_{2}\right), 3.48(\mathrm{dd}, J=8.9$ $\left.\mathrm{Hz}, J=6.7 \mathrm{~Hz}, 2 \mathrm{H}, \mathrm{CH}_{2} \mathrm{CH}_{2} \mathrm{NHCON}\right), 3.33-3.04(\mathrm{~m}, 6 \mathrm{H}$, $\mathrm{CH}_{2} \underline{\mathrm{C}}_{2} \mathrm{NHCON}, \mathrm{C}_{2} \mathrm{NH}_{3}{ }^{+}$, Thiaz $\left.\underline{\mathrm{H}}_{2} \mathrm{CH}_{2}\right), 2.93-2.86$ (m, $2 \mathrm{H}$, Thiaz $\left.\mathrm{CH}_{2} \mathrm{CH}_{2}\right), 2.77\left(\mathrm{t}, J=7.2 \mathrm{~Hz}, 2 \mathrm{H}\right.$, TrizCH$\left.{ }_{2}\right), 1.84-1.71(\mathrm{~m}$, $2 \mathrm{H}$, Triz $\mathrm{CH}_{2} \mathrm{C}_{2}$ ), $1.67-1.56\left(\mathrm{~m}, 2 \mathrm{H}, \mathrm{C}_{2} \mathrm{CH}_{2} \mathrm{NH}_{3}{ }^{+}\right) ;{ }^{13} \mathrm{C} \mathrm{NMR}$ $\left(\mathrm{DMSO}-d_{6}, 75 \mathrm{MHz}\right) \delta(\mathrm{ppm}): 162.1(\mathrm{NHCON}), 159.4\left(\mathrm{OC}_{\mathrm{Ar}}\right)$, $155.6\left(\mathrm{C}_{\mathrm{Ar}}\right), 155.3\left(\mathrm{C}_{\mathrm{Ar}}\right), 147.7\left(\mathrm{C}_{\mathrm{Ar}}\right), 139.0\left(\mathrm{C}_{\mathrm{Ar}}\right), 137.9\left(\mathrm{C}_{\mathrm{Ar}}\right), 133.2$ $\left(\mathrm{CH}_{\mathrm{Ar}}\right), 131.6\left(\mathrm{C}_{\mathrm{Ar}}\right), 129.1\left(\mathrm{CH}_{\mathrm{Ar}}\right), 127.7\left(\mathrm{CH}_{\mathrm{Ar}}\right), 127.4\left(\mathrm{CH}_{\mathrm{Ar}}\right)$, $127.3\left(\mathrm{C}_{\mathrm{Ar}}\right), 126.2\left(\mathrm{CH}_{\mathrm{Ar}}\right), 125.9\left(\mathrm{CH}_{\mathrm{Ar}}\right), 125.2\left(\mathrm{CH}_{\mathrm{Ar}}\right), 121.4$ $\left(\mathrm{CH}_{\mathrm{Ar}}\right), 120.4\left(\mathrm{CH}_{\mathrm{Ar}}\right), 116.1\left(\mathrm{CH}_{\mathrm{Ar}}\right), 112.0\left(\mathrm{CH}_{\mathrm{Ar}}\right), 104.3\left(\mathrm{CH}_{\mathrm{Ar}}\right)$, 67.6 $\left(\mathrm{OCH}_{2}\right), 45.3\left(\mathrm{CH}_{2} \mathrm{CH}_{2} \mathrm{NHCON}\right), 42.4\left(\mathrm{OCH}_{2} \underline{\mathrm{CH}}_{2}\right), 37.5$ $\left(\mathrm{CH}_{2} \mathrm{CH}_{2} \mathrm{NHCON}\right), 34.9$ (Thiaz $\left.\mathrm{CH}_{2} \mathrm{CH}_{2}\right), 32.5\left(\mathrm{ThiazCH}_{2} \mathrm{CH}_{2}\right)$, $26.5\left(\mathrm{CH}_{2} \mathrm{CH}_{2} \mathrm{NH}_{3}{ }^{+}\right), 25.7\left(\operatorname{Triz}_{2} \mathrm{CH}_{2} \mathrm{CH}_{2}\right), 24.8\left(\mathrm{TrizCH}_{2}\right) ; \mathrm{HPLC}$ (gradient A, Agilent): $R_{\mathrm{t}}=7.8 \mathrm{~min}$; HRMS (ES, positive mode) $\mathrm{m} / z$ : calcd for $\mathrm{C}_{32} \mathrm{H}_{35} \mathrm{~N}_{7} \mathrm{O}_{2} \mathrm{~S} 581.2573$; found 581.2572 (-0.13 ppm); anal. calcd for $\mathrm{C}_{32} \mathrm{H}_{35} \mathrm{~N}_{7} \mathrm{O}_{2} \mathrm{~S}$.TFA: C, 58.69; H, 5.22; N, 14.09; S, 4.61; found: C, 58.20; H, 5.01; N, 14.09; S, 4.12.

1-(2-(2-(4-(2-([1, 1'-Biphenyl]-4-yl)ethyl)thiazol-2-yl)-5-(4-(4-ammoniumbutyl)-1 $\mathrm{H}$-1,2,3-triazol-1-yl)phenoxy)ethyl)imidazolidin-2one 2,2,2-Trifluoroacetate (12c). Following the hydrogenolysis procedure, compound 11c (50 mg, $0.07 \mathrm{mmol}), \mathrm{Pd} / \mathrm{C}(10 \%)(20 \%$ $\mathrm{w} / \mathrm{w})(10 \mathrm{mg})$, and TFA $(0.5 \mathrm{~mL})$ in a $1: 1$ mixture of THF/MeOH $(20 \mathrm{~mL})$ were hydrogenated. After the workup, the residue was purified by reverse phase on the Biotage to give $12 \mathrm{c}(17 \mathrm{mg}, 35 \%)$ as a colorless oil. ${ }^{1} \mathrm{H}$ NMR (DMSO- $\left.d_{6}, 500 \mathrm{MHz}\right) \delta(\mathrm{ppm}): 8.77(\mathrm{~s}, 1 \mathrm{H}$, $\mathrm{Ar}), 8.47(\mathrm{~d}, J=8.6 \mathrm{~Hz}, 1 \mathrm{H}, \mathrm{Ar}), 7.75(\mathrm{~d}, J=2.1 \mathrm{~Hz}, 1 \mathrm{H}, \mathrm{Ar}), 7.69$ (dd, $J=8.6,2.1 \mathrm{~Hz}, 1 \mathrm{H}, \mathrm{Ar}), 7.66-7.62(\mathrm{~m}, 2 \mathrm{H}, \mathrm{Ar}), 7.60-7.56(\mathrm{~m}$, $2 \mathrm{H}, \mathrm{Ar}$ ), 7.48-7.39 (m, 3H, Ar), 7.38-7.29 (m, 3H, Ar), 6.41 (bs, $1 \mathrm{H}, \mathrm{NHCON}), 4.47\left(\mathrm{t}, J=5.7 \mathrm{~Hz}, 2 \mathrm{H}, \mathrm{OCH}_{2}\right), 3.63(\mathrm{t}, J=5.7 \mathrm{~Hz}$, $2 \mathrm{H}, \mathrm{OCH}_{2} \underline{\mathrm{CH}}_{2}$ ), 3.49 (dd, $J=9.0,6.7 \mathrm{~Hz}, 2 \mathrm{H}, \mathrm{C}_{2} \mathrm{CH}_{2} \mathrm{NHCON}$ ), 3.21 (dd, $J=9.3,6.5 \mathrm{~Hz}, 2 \mathrm{H}, \mathrm{CH}_{2} \mathrm{CH}_{2} \mathrm{NHCON}$ ), 3.17-2.96 (m, $4 \mathrm{H}$, $\mathrm{C}_{2} \mathrm{NH}_{3}{ }^{+}$, ThiazC $\left.\underline{\mathrm{H}}_{2} \mathrm{CH}_{2}\right), 2.74\left(\mathrm{t}, J=7.4 \mathrm{~Hz}, 2 \mathrm{H}, \mathrm{TrizCH}_{2}\right), 2.69$ $\left(\mathrm{t}, J=7.2 \mathrm{~Hz}, 2 \mathrm{H}\right.$, ThiazCH $\mathrm{CH}_{2}$ ), 1.72 (quin, $J=7.6 \mathrm{~Hz}, 2 \mathrm{H}$, TrizCH $\left.\mathrm{CH}_{2}\right), 1.58-1.42\left(\mathrm{~m}, 2 \mathrm{H}, \quad \mathrm{C}_{2} \mathrm{CH}_{2} \mathrm{NH}_{3}{ }^{+}\right) ;{ }^{13} \mathrm{C} \quad \mathrm{NMR}$ $\left(\mathrm{DMSO}-d_{6}, 100 \mathrm{MHz}\right) \delta(\mathrm{ppm}): 162.1(\mathrm{NHCON}), 159.4\left(\mathrm{OC}_{\mathrm{Ar}}\right)$, $155.6\left(\mathrm{C}_{\mathrm{Ar}}\right), 155.3\left(\mathrm{C}_{\mathrm{Ar}}\right), 148.1\left(\mathrm{C}_{\mathrm{Ar}}\right), 140.7\left(\mathrm{C}_{\mathrm{Ar}}\right), 140.0\left(\mathrm{C}_{\mathrm{Ar}}\right), 138.0$ $\left(\mathrm{C}_{\mathrm{Ar}}\right), 137.8\left(\mathrm{C}_{\mathrm{Ar}}\right), 129.0\left(\mathrm{CH}_{\mathrm{Ar}}\right), 128.9\left(\mathrm{CH}_{\mathrm{Ar}}\right), 128.9\left(\mathrm{CH}_{\mathrm{Ar}}\right), 127.2$ $\left(\mathrm{CH}_{\mathrm{Ar}}\right), 126.5\left(\mathrm{CH}_{\mathrm{Ar}}\right), 126.5\left(\mathrm{CH}_{\mathrm{Ar}}\right), 121.3\left(\mathrm{C}_{\mathrm{Ar}}\right), 120.3\left(\mathrm{CH}_{\mathrm{Ar}}\right)$, 116.0 $\left(\mathrm{CH}_{\mathrm{Ar}}\right), 112.0\left(\mathrm{CH}_{\mathrm{Ar}}\right), 104.3\left(\mathrm{CH}_{\mathrm{Ar}}\right), 67.6\left(\mathrm{OCH}_{2}\right), 45.4$ $\left(\mathrm{CH}_{2} \mathrm{CH}_{2} \mathrm{NHCON}\right), 42.4\left(\mathrm{OCH}_{2} \underline{\mathrm{CH}}_{2}\right), 37.7\left(\mathrm{CH}_{2} \mathrm{NH}_{3}^{+}\right), 37.5$ $\left(\mathrm{CH}_{2} \mathrm{CH}_{2} \mathrm{NHCON}\right.$ ), 34.3 (Thiaz $\mathrm{CH}_{2} \mathrm{CH}_{2}$ ), 32.5 (Thiaz $\mathrm{CH}_{2} \mathrm{CH}_{2}$ ), $30.1\left({ }_{\mathrm{C}} \mathrm{H}_{2} \mathrm{CH}_{2} \mathrm{NH}_{3}^{+}\right), 25.9\left(\operatorname{Triz}_{2} \mathrm{CH}_{2} \mathrm{CH}_{2}\right), 24.7\left(\operatorname{Triz}_{2} \mathrm{H}_{2}\right) ; \mathrm{HPLC}$ (gradient A, Agilent): $R_{\mathrm{t}}=8.4 \mathrm{~min}$; HRMS (ES, positive mode) $\mathrm{m} / z$ : calcd for $\mathrm{C}_{34} \mathrm{H}_{37} \mathrm{~N}_{7} \mathrm{O}_{2} \mathrm{~S}$ 607.2729; found 607.2740 (1.73 ppm); anal. calcd for $\mathrm{C}_{34} \mathrm{H}_{37} \mathrm{~N}_{7} \mathrm{O}_{2} \mathrm{~S}$.TFA: C, 59.91; $\mathrm{H}, 5.31 ; \mathrm{N}, 13.58$; S, 4.44; found: C, 60.08; H, 5.09; N, 13.18; S, 4.20.

Phosphonium (2-Oxo-3-phenylpropyl)triphenyl Chloride (15). A solution of 1-chloro-3-phenylpropan-2-one $(250 \mathrm{mg}, 1.48 \mathrm{mmol})$ and triphenylphosphine $(583 \mathrm{mg}, 2.22 \mathrm{mmol})$ in anhydrous toluene $(8$ $\mathrm{mL}$ ) and under an argon atmosphere was heated to $110^{\circ} \mathrm{C}$ for $6 \mathrm{~h}$ in a pressure tube. After cooling to room temperature, the white solid was filtered and washed with cooled diethyl ether $(3 \times 10 \mathrm{~mL})$ to give 15 (498 mg, 78\%) as a white solid; ${ }^{50}$ m.p.: $200-202{ }^{\circ} \mathrm{C}$; ${ }^{1} \mathrm{H}$ NMR (DMSO- $\left.d_{6}, 400 \mathrm{MHz}\right) \delta(\mathrm{ppm}): 7.93-7.64(\mathrm{~m}, 15 \mathrm{H}, \mathrm{Ar}), 7.31-7.20$ (m, 3H, Ar), $7.12(\mathrm{~d}, J=6.7 \mathrm{~Hz}, 2 \mathrm{H}, \mathrm{Ar}), 5.91(\mathrm{~d}, J=12.7 \mathrm{~Hz}, 2 \mathrm{H}$, $\mathrm{Ar}), 4.14$ (s, 2H, $\left.\mathrm{CH}_{2} \mathrm{CO}\right)$.

(E)-4-([1,1'-Biphenyl]-4-yl)-1-phenylbut-3-en-2-one (16c). A stirred solution of $15(250 \mathrm{mg}, 0.58 \mathrm{mmol})$ and $\mathrm{KOH}(130 \mathrm{mg}$, $2.37 \mathrm{mmol})$ in dry toluene $(15 \mathrm{~mL})$ was heated at $110^{\circ} \mathrm{C}$ in a pressure flask for $3 \mathrm{~h}$. After cooling to room temperature, $\left[1,1^{\prime}\right.$ biphenyl]-4-carboxaldehyde (158 $\mathrm{mg}, 0.87 \mathrm{mmol}$ ) was added dropwise. The reaction mixture was stirred at $110^{\circ} \mathrm{C}$ for 3 additional hours, cooled, and evaporated under reduced pressure. The residue was dissolved in EtOAc $(30 \mathrm{~mL})$, washed with $\mathrm{H}_{2} \mathrm{O}(2 \times 30 \mathrm{~mL})$ and brine $(1 \times 30 \mathrm{~mL})$, dried $\left(\mathrm{Na}_{2} \mathrm{SO}_{4}\right)$, filtered, and evaporated to dryness. The residue was purified by flash column chromatography (hexane/EtOAc, 95:5) to yield $16 \mathrm{c}(107 \mathrm{mg}, 62 \%)$ as a white solid; m.p.: $121-126{ }^{\circ} \mathrm{C} ;{ }^{1} \mathrm{H}$ NMR $\left(\mathrm{CDCl}_{3}, 400 \mathrm{MHz}\right) \delta$ (ppm): 7.59 (d, $J$ $=16.1 \mathrm{~Hz}, 1 \mathrm{H}, \mathrm{CH}=\mathrm{CHCO}), 7.56-7.48(\mathrm{~m}, 6 \mathrm{H}, \mathrm{Ar}), 7.37(\mathrm{t}, J=$ $7.4 \mathrm{~Hz}, 2 \mathrm{H}, \mathrm{Ar}$ ), 7.34-7.25 (m, 3H, Ar), 7.24-7.15 (m, 3H, Ar), 6.74 $(\mathrm{d}, J=16.0 \mathrm{~Hz}, 1 \mathrm{H}, \mathrm{CH}=\mathrm{CHCO}), 3.88\left(\mathrm{~s}, 2 \mathrm{H}, \mathrm{CH}_{2} \mathrm{CO}\right) ;{ }^{13} \mathrm{C}$ NMR $\left(\mathrm{CDCl}_{3}, 75 \mathrm{MHz}\right) \delta(\mathrm{ppm}): 197.4(\mathrm{CO}), 143.5(\mathrm{ArCH}=\mathrm{CH}), 143.1$ $\left(\mathrm{C}_{\mathrm{Ar}}\right), 140.2\left(\mathrm{CH}_{\mathrm{Ar}}\right), 134.6\left(\mathrm{C}_{\mathrm{Ar}}\right), 133.5\left(\mathrm{C}_{\mathrm{Ar}}\right), 129.6\left(\mathrm{CH}_{\mathrm{Ar}}\right), 129.0$ $\left(\mathrm{CH}_{\mathrm{Ar}}\right), 129.0\left(\mathrm{CH}_{\mathrm{Ar}}\right), 128.9\left(\mathrm{CH}_{\mathrm{Ar}}\right), 128.1\left(\mathrm{C}_{\mathrm{Ar}}\right), 127.7(\mathrm{ArCH}=$ $\underline{\mathrm{CH}}), 127.2\left(\mathrm{CH}_{\mathrm{Ar}}\right), 127.1\left(\mathrm{CH}_{\mathrm{Ar}}\right), 125.1\left(\mathrm{CH}_{\mathrm{Ar}}\right), 48.6\left(\underline{\mathrm{CH}}_{2} \mathrm{CO}\right)$; MS (ESI, positive mode) $\mathrm{m} / z: 321.0[\mathrm{M}+\mathrm{Na}]^{+}, 299.3[\mathrm{M}+\mathrm{H}]^{+}$.

(E)-4-(4-Phenyloxyphenyl)-1-phenylbut-3-en-2-one (16d). Following a procedure similar to that described for $16 \mathrm{c}$, a solution of phosphonium salt 15 (700 mg, $1.62 \mathrm{mmol}), \mathrm{KOH}(728 \mathrm{mg}, 13$ $\mathrm{mmol})$, and 4-phenoxybenzaldehyde $(0.34 \mathrm{~mL}, 1.95 \mathrm{mmol})$ in dry toluene $(20 \mathrm{~mL})$ was reacted in a pressure flask. After the workup, the residue was purified by flash column chromatography (hexane/ EtOAc, 95:5) to give $241 \mathrm{mg}$ (47\%) of $\mathbf{1 6 d}$ as a white solid; m.p.: 95-97 ${ }^{\circ} \mathrm{C} ;{ }^{1} \mathrm{H}$ NMR $\left(\mathrm{CDCl}_{3}, 400 \mathrm{MHz}\right) \delta(\mathrm{ppm}): 7.51$ (d, $J=16.0$ $\mathrm{Hz}, 1 \mathrm{H}, \mathrm{C} \underline{\mathrm{H}}=\mathrm{CHCO}), 7.47-7.33(\mathrm{~m}, 2 \mathrm{H}, \mathrm{Ar}), 7.30-7.21(\mathrm{~m}, 4 \mathrm{H}$, $\mathrm{Ar}), 7.19-7.13(\mathrm{~m}, 3 \mathrm{H}, \mathrm{Ar}), 7.06(\mathrm{tt}, J=7.4,1.1 \mathrm{~Hz}, 1 \mathrm{H}, \mathrm{Ar}), 6.97-$ $6.90(\mathrm{~m}, 2 \mathrm{H}, \mathrm{Ar}), 6.89-6.83(\mathrm{~m}, 2 \mathrm{H}, \mathrm{Ar}), 6.60(\mathrm{~d}, J=16.0 \mathrm{~Hz}, 1 \mathrm{H}$, $\mathrm{CH}=\mathrm{CHCO}), 3.83\left(\mathrm{~s}, 2 \mathrm{H}, \mathrm{CH}_{2} \mathrm{CO}\right) ;{ }^{13} \mathrm{C} \mathrm{NMR}\left(\mathrm{CDCl}_{3}, 75 \mathrm{MHz}\right) \delta$ (ppm): $197.3(\mathrm{CO}), 159.9\left(\mathrm{OC}_{\mathrm{Ar}}\right), 156.1\left(\mathrm{OC}_{\mathrm{Ar}}\right), 142.8(\mathrm{ArCH}=$ $\mathrm{CH}), 134.7\left(\mathrm{C}_{\mathrm{Ar}}\right), 130.2\left(\mathrm{CH}_{\mathrm{Ar}}\right), 130.0\left(\mathrm{CH}_{\mathrm{Ar}}\right), 129.6\left(\mathrm{CH}_{\mathrm{Ar}}\right), 129.2$ $\left(\mathrm{C}_{\mathrm{Ar}}\right), 128.9\left(\mathrm{CH}_{\mathrm{Ar}}\right), 127.1(\mathrm{ArCH}=\mathrm{CH}), 124.3\left(\mathrm{CH}_{\mathrm{Ar}}\right), 124.0$ $\left(\mathrm{CH}_{\mathrm{Ar}}\right), 119.8\left(\mathrm{CH}_{\mathrm{Ar}}\right), 118.5\left(\mathrm{CH}_{\mathrm{Ar}}\right), 48.5\left(\mathrm{CH}_{2} \mathrm{CO}\right) ; \mathrm{MS}$ (ESI, positive mode) $\mathrm{m} / z: 337.0[\mathrm{M}+\mathrm{Na}]^{+}, 315.0[\mathrm{M}+\mathrm{H}]^{+}$.

General Procedure for the Synthesis of $\alpha$-Bromomethylketones $17 \boldsymbol{a}-\boldsymbol{d}$. To a solution of the corresponding ketone (1 equiv) in $\mathrm{CH}_{3} \mathrm{CN}, p$-TsOH (1.3-2.6 equiv) and NBS (1.3-2.6 equiv) were successively added at room temperature and the mixture was stirred for $6 \mathrm{~h}$ /overnight. After quenching with $\mathrm{H}_{2} \mathrm{O}(30 \mathrm{~mL})$, the reaction mixture was carefully concentrated under reduced pressure without heating. The aqueous crude was extracted with EtOAc $(3 \times 30 \mathrm{~mL})$, and the organic layers were dried $\left(\mathrm{Na}_{2} \mathrm{SO}_{4}\right)$, filtered, and evaporated to dryness. The residue was purified by flash column chromatography or CCTLC on the Chromatotron (the eluents are specified in each case) to give the desired $\alpha$-bromoketones $17 \mathbf{a}-\mathbf{d}$.

2-([1,1'-Biphenyl]-4-yl)-1-bromo-1-phenylethan-2-one (17a). Following the general bromination procedure, $p-\mathrm{TsOH}(173 \mathrm{mg}$, $0.92 \mathrm{mmol}$ ) and NBS (165 mg, $0.92 \mathrm{mmol}$ ) were successively added to a solution of the commercially available $16 \mathrm{a}(50 \mathrm{mg}, 0.18 \mathrm{mmol})$ in $\mathrm{CH}_{3} \mathrm{CN}(15 \mathrm{~mL})$. The reaction was stirred at room temperature overnight. After the workup, the residue was purified by CCTLC on the Chromatotron (hexane/EtOAc, 80:20) to give $62 \mathrm{mg}$ (98\%) of $17 \mathbf{a}$ as a white solid; m.p.: decompose without melting; ${ }^{1} \mathrm{H}$ NMR 
$\left(\mathrm{CDCl}_{3}, 400 \mathrm{MHz}\right) \delta(\mathrm{ppm}): 8.08(\mathrm{~d}, J=8.2 \mathrm{~Hz}, 2 \mathrm{H}, \mathrm{Ar}), 7.67(\mathrm{~d}, J$ $=8.4 \mathrm{~Hz}, 2 \mathrm{H}, \mathrm{Ar}), 7.63-7.54(\mathrm{~m}, 4 \mathrm{H}, \mathrm{Ar}), 7.47(\mathrm{t}, J=7.5 \mathrm{~Hz}, 2 \mathrm{H}$, $\mathrm{Ar}), 7.43-7.29$ (m, 4H, Ar), 6.43 (s, 1H, BrCHCO).

2-(4-Phenyloxyphenyl)-1-bromo-1-phenylethan-2-one (17b). The general bromination procedure was followed with the commercially available $16 \mathbf{b}(150 \mathrm{mg}, 0.52 \mathrm{mmol}), \mathrm{p}-\mathrm{TsOH}(297$ $\mathrm{mg}, 1.56 \mathrm{mmol})$, and NBS (278 mg, $1.56 \mathrm{mmol})$ in $\mathrm{CH}_{3} \mathrm{CN}(22 \mathrm{~mL})$ at room temperature overnight. The residue was purified by CCTLC on the Chromatotron (hexane $/ \mathrm{CH}_{2} \mathrm{Cl}_{2}, 70: 30$ ) to afford $\mathbf{1 7 b}$ (140 mg, 73\%) as a white solid; m.p.: $116-118{ }^{\circ} \mathrm{C}$; ${ }^{1} \mathrm{H}$ NMR $\left(\mathrm{CDCl}_{3}, 400\right.$ $\mathrm{MHz}) \delta(\mathrm{ppm}): 7.97(\mathrm{~d}, J=8.9 \mathrm{~Hz}, 2 \mathrm{H}, \mathrm{Ar}), 7.53(\mathrm{dd}, J=8.1,1.6 \mathrm{~Hz}$, $2 \mathrm{H}, \mathrm{Ar}$ ), 7.44-7.29 (m, $5 \mathrm{H}, \mathrm{Ar}), 7.22(\mathrm{tt}, J=7.3,1.0 \mathrm{~Hz}, 1 \mathrm{H}, \mathrm{Ar})$, 7.06 (dd, $J=7.9,1.6 \mathrm{~Hz}, 2 \mathrm{H}, \mathrm{Ar}), 6.96(\mathrm{~d}, J=8.9 \mathrm{~Hz}, 2 \mathrm{H}, \mathrm{Ar}), 6.34$ (s, $1 \mathrm{H}, \mathrm{BrCHCO}) ;{ }^{13} \mathrm{C}$ NMR $\left(\mathrm{CDCl}_{3}, 75 \mathrm{MHz}\right) \delta(\mathrm{ppm}): 189.7$ (CO), $162.7\left(\mathrm{OC}_{\mathrm{Ar}}\right), 155.1\left(\mathrm{OC}_{\mathrm{Ar}}\right), 136.2\left(\mathrm{C}_{\mathrm{Ar}}\right), 131.7\left(\mathrm{CH}_{\mathrm{Ar}}\right), 130.3$ $\left(\mathrm{CH}_{\mathrm{Ar}}\right), 129.2\left(\mathrm{CH}_{\mathrm{Ar}}\right), 129.2\left(\mathrm{CH}_{\mathrm{Ar}}\right), 128.5\left(\mathrm{C}_{\mathrm{Ar}}\right), 125.1\left(\mathrm{CH}_{\mathrm{Ar}}\right)$, $120.6\left(\mathrm{CH}_{\mathrm{Ar}}\right), 117.4\left(\mathrm{CH}_{\mathrm{Ar}}\right), 51.2(\mathrm{Br} \underline{\mathrm{CHCO}}) ; \mathrm{MS}$ (ESI, positive mode) $m / z: 389[\mathrm{M}+\mathrm{Na}]^{+}$with a $\mathrm{Br}$ isotopic pattern.

(E)-4-([1,1'-Biphenyl]-4-yl)-1-bromo-1-phenylbut-3-en-2-one (17c). Following the general procedure, compound $16 \mathrm{c}$ (200 mg, 0.67 mmol) dissolved in $\mathrm{CH}_{3} \mathrm{CN}(25 \mathrm{~mL})$ was sequentially treated with $p$ TsOH $(191 \mathrm{mg}, 1.00 \mathrm{mmol})$ and NBS $(179 \mathrm{mg}, 1.00 \mathrm{mmol})$ at room temperature for $4 \mathrm{~h}$. After the workup, the residue was purified by flash column chromatography (hexane/EtOAc, 90:10) to give $17 \mathrm{c}$ (253 mg, 79\%) as a white solid; m.p.: $118-120{ }^{\circ} \mathrm{C}$; ${ }^{1} \mathrm{H}$ NMR $\left(\mathrm{CDCl}_{3}, 400 \mathrm{MHz}\right) \delta(\mathrm{ppm}): 7.71(\mathrm{~d}, J=15.8 \mathrm{~Hz}, 1 \mathrm{H}, \mathrm{C} \underline{\mathrm{H}}=$ CHCO), 7.56-7.49 (m, 6H, Ar), 7.47-7.42 (m, 2H, Ar), 7.41-7.34 (m, 2H, Ar), 7.35-7.24 (m, 4H, Ar), $6.94(\mathrm{~d}, J=15.8 \mathrm{~Hz}, 1 \mathrm{H}, \mathrm{CH}=$ C $\underline{H C O}), 5.61$ (s, $1 \mathrm{H}, \mathrm{BrCHCO}) ;{ }^{13} \mathrm{C}$ NMR $\left(\mathrm{CDCl}_{3}, 75 \mathrm{MHz}\right) \delta$ $(\mathrm{ppm}): 190.4(\mathrm{CO}), 145.0 \quad(\mathrm{Ar} \underline{\mathrm{CH}}=\mathrm{CH}), 143.9\left(\mathrm{C}_{\mathrm{Ar}}\right), 140.1$ $\left(\mathrm{CH}_{\mathrm{Ar}}\right), 135.4\left(\mathrm{C}_{\mathrm{Ar}}\right), 133.2\left(\mathrm{C}_{\mathrm{Ar}}\right), 129.3\left(\mathrm{CH}_{\mathrm{Ar}}\right), 129.3\left(\mathrm{CH}_{\mathrm{Ar}}\right)$, $129.2\left(\mathrm{CH}_{\mathrm{Ar}}\right), 129.1\left(\mathrm{CH}_{\mathrm{Ar}}\right), 128.1\left(\mathrm{C}_{\mathrm{Ar}}\right), 127.7(\mathrm{ArCH}=\mathrm{CH}), 127.2$ $\left(\mathrm{CH}_{\mathrm{Ar}}\right), 127.1\left(\mathrm{CH}_{\mathrm{Ar}}\right), 121.4\left(\mathrm{CH}_{\mathrm{Ar}}\right), 55.5(\mathrm{Br} \underline{\mathrm{CHCO}})$.

(E)-4-(4-Phenyloxyphenyl)-1-phenylbut-3-en-2-one (17d). According to the general bromination procedure, the $\alpha, \beta$-unsaturated compound 16d (211 mg, $0.67 \mathrm{mmol}), p-\mathrm{TsOH}(140 \mathrm{mg}, 0.74 \mathrm{mmol})$, and NBS (131 mg, $0.74 \mathrm{mmol})$ dissolved in $\mathrm{CH}_{3} \mathrm{CN}(25 \mathrm{~mL})$ were reacted at room temperature for $4 \mathrm{~h}$. After the workup, the crude was purified by flash column chromatography (hexane/EtOAc, 97:3) to give $17 \mathrm{~d}(150 \mathrm{mg}, 39 \%)$ as a yellow oil. ${ }^{1} \mathrm{H} \mathrm{NMR}\left(\mathrm{CDCl}_{3}, 400 \mathrm{MHz}\right)$ $\delta(\mathrm{ppm}): 7.72(\mathrm{~d}, J=15.7 \mathrm{~Hz}, 1 \mathrm{H}, \mathrm{CH}=\mathrm{CHCO}), 7.56-7.47(\mathrm{~m}$, $4 \mathrm{H}, \mathrm{Ar}), 7.43-7.32(\mathrm{~m}, 5 \mathrm{H}, \mathrm{Ar}), 7.18(\mathrm{tt}, J=7.4,1.1 \mathrm{~Hz}, 1 \mathrm{H}, \mathrm{Ar})$, 7.10-7.01 (m, 2H, Ar), 6.97 (d, $J=8.8 \mathrm{~Hz}, 2 \mathrm{H}, \mathrm{Ar}), 6.89$ (d, $J=15.7$ $\mathrm{Hz}, 1 \mathrm{H}, \mathrm{CH}=\mathrm{CHCO}), 5.66(\mathrm{~s}, 1 \mathrm{H}, \mathrm{BrCHCO}) ;{ }^{13} \mathrm{C} \mathrm{NMR}\left(\mathrm{CDCl}_{3}\right.$, $75 \mathrm{MHz}) \delta(\mathrm{ppm}): 190.4(\mathrm{CO}), 160.4\left(\mathrm{OC}_{\mathrm{Ar}}\right), 156.0\left(\mathrm{OC}_{\mathrm{Ar}}\right), 144.8$ $(\mathrm{Ar} \underline{\mathrm{CH}}=\mathrm{CH}), 135.5\left(\mathrm{C}_{\mathrm{Ar}}\right), 130.6\left(\mathrm{CH}_{\mathrm{Ar}}\right), 130.1\left(\mathrm{CH}_{\mathrm{Ar}}\right), 129.2$ $\left(\mathrm{CH}_{\mathrm{Ar}}\right), 129.1\left(\mathrm{C}_{\mathrm{Ar}}\right), 129.1\left(\mathrm{CH}_{\mathrm{Ar}}\right), 128.9(\mathrm{ArCH}=\mathrm{CH}), 124.5$ $\left(\mathrm{CH}_{\mathrm{Ar}}\right), 120.2\left(\mathrm{CH}_{\mathrm{Ar}}\right), 120.0\left(\mathrm{CH}_{\mathrm{Ar}}\right), 118.5\left(\mathrm{CH}_{\mathrm{Ar}}\right), 55.5$ (BrCHCO); MS (ESI, positive mode) $m / z: 417.0[\mathrm{M}+\mathrm{Na}]^{+}$, $393.0[\mathrm{M}+\mathrm{H}]^{+}$with a $\mathrm{Br}$ isotopic pattern.

Benzyl-(4-(1-(4-(4,5-diphenylthiazol-2-yl)-3-(2-(2-oxoimidazolidin-1-yl)ethoxy)phenyl)-1 $\mathrm{H}-1,2,3$-triazol-4-yl)butyl)carbamate (18a). Following the general procedure of Hantzsch synthesis, the thioamide $9(150 \mathrm{mg}, 0.28 \mathrm{mmol})$ and the commercially available 1bromo-1,2-diphenylethan-2-one $17 \mathrm{e}(77 \mathrm{mg}, 0.28 \mathrm{mmol})$ reacted in ${ }^{i} \mathrm{PrOH}(20 \mathrm{~mL})$. After the workup, the final residue was purified by CCTLC in the Chromatotron $\left(\mathrm{CH}_{2} \mathrm{Cl}_{2} / \mathrm{MeOH}, 97: 3\right)$ to provide 191 $\mathrm{mg}(94 \%)$ of $18 \mathrm{a}$ as a colorless oil. ${ }^{1} \mathrm{H}$ NMR $\left(\mathrm{CDCl}_{3}, 400 \mathrm{MHz}\right) \delta$ (ppm): 8.62 (d, $J=8.6 \mathrm{~Hz}, 1 \mathrm{H}, \mathrm{Ar}), 7.89(\mathrm{~s}, 1 \mathrm{H}, \mathrm{Ar}), 7.64-7.57(\mathrm{~m}$, $3 \mathrm{H}, \mathrm{Ar}), 7.44-7.23(\mathrm{~m}, 14 \mathrm{H}, \mathrm{Ar}), 5.19(\mathrm{t}, J=6.0 \mathrm{~Hz}, 1 \mathrm{H}, \mathrm{NHCbz})$, $5.08\left(\mathrm{~s}, 2 \mathrm{H}, \mathrm{NHCOOC} \underline{\mathrm{H}}_{2}\right), 4.87$ (bs, $\left.1 \mathrm{H}, \mathrm{NHCON}\right), 4.44(\mathrm{t}, J=5.9$ $\left.\mathrm{Hz}, 2 \mathrm{H}, \mathrm{OCH}_{2}\right), 3.75\left(\mathrm{t}, J=5.8 \mathrm{~Hz}, 2 \mathrm{H}, \mathrm{OCH}_{2} \mathrm{CH}_{2}\right), 3.57$ (dd, $J=$ 9.0, $\left.6.7 \mathrm{~Hz}, 2 \mathrm{H}, \mathrm{CH}_{2} \mathrm{CH}_{2} \mathrm{NHCON}\right), 3.29(\mathrm{t}, J=8.0 \mathrm{~Hz}, 2 \mathrm{H}$, $\left.\mathrm{CH}_{2} \mathrm{CH}_{2} \mathrm{NHCON}\right), 3.25\left(\mathrm{q}, J=6.9 \mathrm{~Hz}, 2 \mathrm{H}, \mathrm{CH}_{2} \mathrm{NHCbz}\right), 2.82(\mathrm{t}, J$ $\left.=7.4 \mathrm{~Hz}, 2 \mathrm{H}, \mathrm{TrizCH}_{2}\right), 1.84-1.71\left(\mathrm{~m}, 2 \mathrm{H}, \mathrm{TrizCH}_{2} \mathrm{CH}_{2}\right), 1.62$ (quin, $\left.J=6.2 \mathrm{~Hz}, 2 \mathrm{H}, \mathrm{CH}_{2} \mathrm{CH}_{2} \mathrm{NHCbz}\right) ;{ }^{13} \mathrm{C} \mathrm{NMR}\left(\mathrm{CDCl}_{3}, 75\right.$ $\mathrm{MHz}) \delta(\mathrm{ppm}): 162.2(\mathrm{NHCON}), 158.3\left(\mathrm{OC}_{\mathrm{Ar}}\right), 156.6\left(\mathrm{C}_{\mathrm{Ar}}\right), 155.9$ $\left(\mathrm{C}_{\mathrm{Ar}}\right), 149.3\left(\mathrm{C}_{\mathrm{Ar}}\right), 148.7\left(\mathrm{C}_{\mathrm{Ar}}\right), 138.4\left(\mathrm{C}_{\mathrm{Ar}}\right), 136.7\left(\mathrm{C}_{\mathrm{Ar}}\right), 135.1$ $\left(\mathrm{C}_{\mathrm{Ar}}\right), 134.3\left(\mathrm{C}_{\mathrm{Ar}}\right), 132.2\left(\mathrm{CH}_{\mathrm{Ar}}\right), 129.7\left(\mathrm{CH}_{\mathrm{Ar}}\right), 129.6\left(\mathrm{CH}_{\mathrm{Ar}}\right), 129.2$ $\left(\mathrm{CH}_{\mathrm{Ar}}\right), 129.1\left(\mathrm{CH}_{\mathrm{Ar}}\right), 128.8\left(\mathrm{CH}_{\mathrm{Ar}}\right), 128.6\left(\mathrm{CH}_{\mathrm{Ar}}\right), 128.4\left(\mathrm{CH}_{\mathrm{Ar}}\right)$,
$128.2\left(\mathrm{CH}_{\mathrm{Ar}}\right), 127.9\left(\mathrm{C}_{\mathrm{Ar}}\right), 122.5\left(\mathrm{CH}_{\mathrm{Ar}}\right), 119.1\left(\mathrm{CH}_{\mathrm{Ar}}\right), 112.4$ $\left(\mathrm{CH}_{\mathrm{Ar}}\right), 104.4\left(\mathrm{CH}_{\mathrm{Ar}}\right), 67.7\left(\mathrm{OCH}_{2}\right), 66.7\left(\mathrm{NHCOOCH}_{2}\right), 46.4$ $\left(\mathrm{CH}_{2} \mathrm{CH}_{2} \mathrm{NHCON}\right), 42.9\left(\mathrm{OCH}_{2} \mathrm{CH}_{2}\right), 40.8\left(\mathrm{CH}_{2} \mathrm{NHCbz}\right), 38.4$ $\left(\mathrm{CH}_{2} \mathrm{CH}_{2} \mathrm{NHCON}\right), 29.4\left(\mathrm{CH}_{2} \mathrm{CH}_{2} \mathrm{NHCbz}\right), 26.3\left(\mathrm{TrizCH}_{2} \mathrm{CH}_{2}\right)$, $25.2\left(\mathrm{Triz}_{2}\right)$; HRMS (ES, positive mode) $\mathrm{m} / z$ : calcd for $\mathrm{C}_{40} \mathrm{H}_{39} \mathrm{~N}_{7} \mathrm{O}_{4} \mathrm{~S}$ 713.2784; found 713.2786 (0.23 ppm).

Benzyl-(4-(1-(3-(2-(2-oxoimidazolidin-1-yl)ethoxy)-4-(4-([1, 1'-biphenyl]-4-yl)-5-phenylthiazol-2-yl)phenyl)-1H-1,2,3-triazol-4-yl)butyl)carbamate (18b). Following the general procedure for the synthesis of thiazoles by Hantzsch cyclization, thioamide 9 (194 mg, $0.36 \mathrm{mmol})$ reacted with $\alpha$-bromoketone $17 \mathrm{a}(127 \mathrm{mg}, 0.36 \mathrm{mmol})$ in ${ }^{i} \mathrm{PrOH}(20 \mathrm{~mL})$. After the workup, the residue was purified by CCTLC on the Chromatotron $\left(\mathrm{CH}_{2} \mathrm{Cl}_{2} / \mathrm{MeOH}, 95: 5\right)$ to give $\mathbf{1 8 b}$ $(244 \mathrm{mg}, 84 \%)$ as a colorless oil. ${ }^{1} \mathrm{H}$ NMR $\left(\mathrm{CDCl}_{3}, 400 \mathrm{MHz}\right) \delta$ (ppm): 8.66 (d, $J=8.6 \mathrm{~Hz}, 1 \mathrm{H}, \mathrm{Ar}), 7.60(\mathrm{~s}, 1 \mathrm{H}, \mathrm{Ar}), 7.71(\mathrm{~d}, J=8.1$ $\mathrm{Hz}, 2 \mathrm{H}, \mathrm{Ar}$ ), 7.65-7.51 (m, 3H, Ar), $7.56(\mathrm{~d}, J=8.1 \mathrm{~Hz}, 2 \mathrm{H}, \mathrm{Ar})$ 7.52-7.18 (m, 14H, Ar), 5.13 (bs, $1 \mathrm{H}, \mathrm{NHCON}), 5.10(\mathrm{~s}, 2 \mathrm{H}$, $\left.\mathrm{NCOOCH}_{2}\right), 4.67(\mathrm{bs}, 1 \mathrm{H}, \mathrm{NHCbz}), 4.47\left(\mathrm{t}, J=5.9 \mathrm{~Hz}, 2 \mathrm{H}, \mathrm{OCH}_{2}\right)$, $3.78\left(\mathrm{t}, J=5.9 \mathrm{~Hz}, 2 \mathrm{H}, \mathrm{OCH}_{2} \mathrm{CH}_{2}\right), 3.59(\mathrm{dd}, J=9.0,6.7 \mathrm{~Hz}, 2 \mathrm{H}$, $\left.\mathrm{C}_{2} \mathrm{CH}_{2} \mathrm{NHCON}\right), 3.37-3.22\left(\mathrm{~m}, 4 \mathrm{H}, \mathrm{CH}_{2} \mathrm{C}_{2} \mathrm{NHCON}\right.$, $\left.\mathrm{CH}_{2} \mathrm{NHCbz}\right), 2.84\left(\mathrm{t}, J=7.3 \mathrm{~Hz}, 2 \mathrm{H}, \mathrm{TrizCH}_{2}\right), 1.86-1.74(\mathrm{~m}$, $2 \mathrm{H}$, TrizCH $\mathrm{C}_{2}$ ), 1.64 (quin, $J=7.2 \mathrm{~Hz}, 2 \mathrm{H}, \mathrm{C}_{2} \mathrm{CH}_{2} \mathrm{NHCbz}$ ); ${ }^{13} \mathrm{C}$ NMR $\left(\mathrm{CDCl}_{3}, 75 \mathrm{MHz}\right) \delta(\mathrm{ppm}): 162.7(\mathrm{NHCON}), 158.4$ $\left(\mathrm{OC}_{\mathrm{Ar}}\right), 156.6\left(\mathrm{C}_{\mathrm{Ar}}\right), 156.0(\mathrm{NHCOO}), 149.0\left(\mathrm{C}_{\mathrm{Ar}}\right), 148.8\left(\mathrm{C}_{\mathrm{Ar}}\right)$, $140.8\left(\mathrm{C}_{\mathrm{Ar}}\right), 140.5\left(\mathrm{C}_{\mathrm{Ar}}\right), 138.5\left(\mathrm{C}_{\mathrm{Ar}}\right), 136.7\left(\mathrm{C}_{\mathrm{Ar}}\right), 134.4\left(\mathrm{C}_{\mathrm{Ar}}\right), 134.1$ $\left(\mathrm{CH}_{\mathrm{Ar}}\right), 132.3\left(\mathrm{C}_{\mathrm{Ar}}\right), 129.8\left(\mathrm{CH}_{\mathrm{Ar}}\right), 129.5\left(\mathrm{CH}_{\mathrm{Ar}}\right), 128.9\left(\mathrm{CH}_{\mathrm{Ar}}\right)$, $128.9\left(\mathrm{CH}_{\mathrm{Ar}}\right), 128.6\left(\mathrm{CH}_{\mathrm{Ar}}\right), 128.3\left(\mathrm{CH}_{\mathrm{Ar}}\right), 128.2\left(\mathrm{CH}_{\mathrm{Ar}}\right), 127.5$ $\left(\mathrm{C}_{\mathrm{Ar}}\right), 127.1\left(\mathrm{CH}_{\mathrm{Ar}}\right), 122.5\left(\mathrm{CH}_{\mathrm{Ar}}\right), 119.2\left(\mathrm{C}_{\mathrm{Ar}}\right), 112.5\left(\mathrm{CH}_{\mathrm{Ar}}\right), 104.5$ $\left(\mathrm{CH}_{\mathrm{Ar}}\right), 67.7\left(\mathrm{NHCOO}_{2} \mathrm{H}_{2}\right), \quad 66.8\left(\mathrm{OCH}_{2}\right), 46.4$ $\left(\mathrm{CH}_{2} \mathrm{CH}_{2} \mathrm{NHCON}\right), 42.9\left(\mathrm{OCH}_{2} \mathrm{CH}_{2}\right), 40.9\left(\mathrm{CH}_{2} \mathrm{NHCbz}\right), 38.4$ $\left(\mathrm{CH}_{2} \mathrm{CH}_{2} \mathrm{NHCON}\right), 29.4\left(\mathrm{CH}_{2} \mathrm{CH}_{2} \mathrm{NHCbz}\right), 26.4\left(\mathrm{TrizCH}_{2} \mathrm{CH}_{2}\right)$, $25.2\left(\mathrm{Triz}_{\mathrm{CH}}\right)$; HRMS (ES, positive mode) $\mathrm{m} / z$ : calcd for $\mathrm{C}_{46} \mathrm{H}_{43} \mathrm{~N}_{7} \mathrm{O}_{4} \mathrm{~S}$ 789.3097; found 789.3063 (-4.31 ppm).

Benzyl-(4-(1-(3-(2-(2-oxoimidazolidin-1-yl)ethoxy)-4-(4-(4-phenyloxyphenyl-1-yl)-5-phenylthiazol-2-yl)phenyl)-1H-1,2,3-triazol-4yl)butyl)carbamate (18c). Following the general procedure for the synthesis of thiazoles by Hantzsch cyclization, thioamide 9 (190 mg, $0.35 \mathrm{mmol})$ and $\alpha$-bromoketone $17 \mathrm{~b}(130 \mathrm{mg}, 0.35 \mathrm{mmol})$ reacted in ${ }^{i} \mathrm{PrOH}(20 \mathrm{~mL})$. The final residue was purified by CCTLC in the Chromatotron $\left(\mathrm{CH}_{2} \mathrm{Cl}_{2} / \mathrm{MeOH}, 95: 5\right)$ to yield $235 \mathrm{mg}(81 \%)$ of $18 \mathrm{c}$ a colorless oil. ${ }^{1} \mathrm{H}$ NMR $\left(\mathrm{CDCl}_{3}, 400 \mathrm{MHz}\right) \delta(\mathrm{ppm}): 8.63(\mathrm{~d}, J=8.5$ $\mathrm{Hz}, 1 \mathrm{H}, \mathrm{Ar}), 7.90$ (s, 1H, Ar), 7.65-7.55 (m, 3H, Ar), 7.47-7.24 (m, $13 \mathrm{H}, \mathrm{Ar}), 7.11(\mathrm{t}, J=7.4 \mathrm{~Hz}, 1 \mathrm{H}, \mathrm{Ar}), 7.04(\mathrm{~d}, J=8.0 \mathrm{~Hz}, 2 \mathrm{H}, \mathrm{Ar})$ $6.95(\mathrm{~d}, J=8.3 \mathrm{~Hz}, 2 \mathrm{H}, \mathrm{Ar}), 5.14(\mathrm{bs}, 1 \mathrm{H}, \mathrm{NHCON}), 5.09(\mathrm{~s}, 2 \mathrm{H}$ $\left.\mathrm{NCOOCH}_{2}\right), 4.73(\mathrm{bs}, 1 \mathrm{H}, \mathrm{NHCbz}), 4.46\left(\mathrm{t}, J=5.9 \mathrm{~Hz}, 2 \mathrm{H}, \mathrm{OCH}_{2}\right)$, $3.77\left(\mathrm{t}, J=5.9 \mathrm{~Hz}, 2 \mathrm{H}, \mathrm{OCH}_{2} \mathrm{CH}_{2}\right), 3.59(\mathrm{dd}, J=9.0,6.7 \mathrm{~Hz}, 2 \mathrm{H}$, $\left.\mathrm{CH}_{2} \mathrm{CH}_{2} \mathrm{NHCON}\right), 3.37-3.21\left(\mathrm{~m}, 4 \mathrm{H}, \mathrm{CH}_{2} \underline{\mathrm{C}}_{2} \mathrm{NHCON}\right.$, $\left.\mathrm{C}_{2}{ }_{2} \mathrm{NHCbz}\right), 2.84\left(\mathrm{t}, J=7.3 \mathrm{~Hz}, 2 \mathrm{H}, \mathrm{TrizCH}_{2}\right), 1.84-1.74(\mathrm{~m}$, $2 \mathrm{H}$, Triz $\mathrm{CH}_{2} \mathrm{CH}_{2}$ ), 1.63 (quin, $J=7.2 \mathrm{~Hz}, 2 \mathrm{H}, \mathrm{CH}_{2} \mathrm{CH}_{2} \mathrm{NHCbz}$ ); ${ }^{13} \mathrm{C}$ NMR $\left(\mathrm{CDCl}_{3}, 75 \mathrm{MHz}\right) \delta(\mathrm{ppm}): 162.7$ (NHCON), 158.3 $\left(\mathrm{OC}_{\mathrm{Ar}}\right), 157.2\left(\mathrm{C}_{\mathrm{Ar}}\right), 157.0\left(\mathrm{OC}_{\mathrm{Ar}}\right), 156.6\left(\mathrm{OC}_{\mathrm{Ar}}\right), 156.0(\mathrm{NHCOO})$, $148.8\left(\mathrm{C}_{\mathrm{Ar}}\right), 138.5\left(\mathrm{C}_{\mathrm{Ar}}\right), 136.7\left(\mathrm{C}_{\mathrm{Ar}}\right), 133.7\left(\mathrm{C}_{\mathrm{Ar}}\right), 132.3\left(\mathrm{C}_{\mathrm{Ar}}\right), 130.7$ $\left(\mathrm{CH}_{\mathrm{Ar}}\right), 130.1\left(\mathrm{C}_{\mathrm{Ar}}\right), 129.9\left(\mathrm{CH}_{\mathrm{Ar}}\right), 129.7\left(\mathrm{CH}_{\mathrm{Ar}}\right), 129.7\left(\mathrm{CH}_{\mathrm{Ar}}\right)$, $128.9\left(\mathrm{CH}_{\mathrm{Ar}}\right), 128.6\left(\mathrm{CH}_{\mathrm{Ar}}\right), 128.2\left(\mathrm{C}_{\mathrm{Ar}}\right), 128.2\left(\mathrm{CH}_{\mathrm{Ar}}\right), 123.6$ $\left(\mathrm{CH}_{\mathrm{Ar}}\right), 122.5\left(\mathrm{C}_{\mathrm{Ar}}\right), 119.3\left(\mathrm{CH}_{\mathrm{Ar}}\right), 119.1\left(\mathrm{C}_{\mathrm{Ar}}\right), 118.6\left(\mathrm{CH}_{\mathrm{Ar}}\right), 112.5$ $\left(\mathrm{CH}_{\mathrm{Ar}}\right), 104.5\left(\mathrm{CH}_{\mathrm{Ar}}\right), 67.7\left(\mathrm{NHCOOCH}_{2}\right), 66.8\left(\mathrm{OCH}_{2}\right), 46.4$ $\left(\mathrm{CH}_{2} \mathrm{CH}_{2} \mathrm{NHCON}\right), 42.9\left(\mathrm{OCH}_{2} \mathrm{CH}_{2}\right), 40.9\left(\mathrm{CH}_{2} \mathrm{NHCbz}\right), 38.4$ $\left(\mathrm{CH}_{2} \mathrm{CH}_{2} \mathrm{NHCON}\right), 29.4\left(\mathrm{CH}_{2} \mathrm{CH}_{2} \mathrm{NHCbz}\right), 26.3\left(\mathrm{TrizCH}_{2} \mathrm{CH}_{2}\right)$, $25.2\left(\mathrm{Triz}_{2}\right)$; HRMS (ES, positive mode) $\mathrm{m} / \mathrm{z}$ : calcd for $\mathrm{C}_{46} \mathrm{H}_{43} \mathrm{~N}_{7} \mathrm{O}_{5} \mathrm{~S}$ 805.3046; found 805.3054 (0.92 ppm).

Benzyl-(E)-(4-(1-(4-(4-(2-([1,1'-biphenyl]-4-yl)vinyl)-5-phenylthiazol-2-yl)-3-(2-(2-oxoimidazolidin-1-yl)ethoxy) phenyl)- $1 \mathrm{H}$ 1,2,3-triazol-4-yl)butyl)carbamate (18d). Following the general Hantzsch cyclization procedure, thioamide $9(200 \mathrm{mg}, 0.37 \mathrm{mmol})$ and $\alpha$-bromoketone $17 \mathrm{c}(140 \mathrm{mg}, 0.37 \mathrm{mmol})$ reacted in ${ }^{i} \mathrm{PrOH}(20$ $\mathrm{mL}$ ). After the workup, the residue was purified by CCTLC on the Chromatotron $\left(\mathrm{CH}_{2} \mathrm{Cl}_{2} / \mathrm{MeOH}, 95: 5\right)$ to give $\mathbf{1 8 d}(183 \mathrm{mg}, 59 \%)$ as a yellow oil. ${ }^{1} \mathrm{H}$ NMR (DMSO- $\left.d_{6}, 400 \mathrm{MHz}\right) \delta(\mathrm{ppm}): 8.72(\mathrm{~s}, 1 \mathrm{H}$, $\mathrm{Ar}), 8.61(\mathrm{~d}, J=8.4 \mathrm{~Hz}, 1 \mathrm{H}, \mathrm{Ar}), 7.80-7.71(\mathrm{~m}, 3 \mathrm{H}, \mathrm{Ar}$, ThiazCH$=$ $\mathrm{C} \underline{\mathrm{H}}$ ), 7.70-7.53 (m, 10H, Ar), 7.51-7.42 (m, 3H, Ar), 7.39-7.27 
(m, 3H, Ar, NHCbz), $7.24(\mathrm{~d}, J=15.7 \mathrm{~Hz}, 1 \mathrm{H}, \mathrm{ThiazC} \underline{\mathrm{H}}=\mathrm{CH}), 6.42$ (bs, $1 \mathrm{H}, \mathrm{NHCON}), 5.02\left(\mathrm{~s}, 2 \mathrm{H}, \mathrm{NHCOOCH}_{2}\right), 4.48(\mathrm{t}, J=5.7 \mathrm{~Hz}$, $\left.2 \mathrm{H}, \mathrm{OCH}_{2}\right), 3.66\left(\mathrm{t}, J=5.6 \mathrm{~Hz}, 2 \mathrm{H}, \mathrm{OCH}_{2} \mathrm{CH}_{2}\right), 3.49(\mathrm{dd}, J=9.0$, $\left.6.6 \mathrm{~Hz}, 2 \mathrm{H}, \mathrm{CH}_{2} \mathrm{CH}_{2} \mathrm{NHCON}\right), 3.23(\mathrm{dd}, J=9.0,6.7 \mathrm{~Hz}, 2 \mathrm{H}$, $\mathrm{CH}_{2} \mathrm{CH}_{2} \mathrm{NHCON}$ ), 3.08 (q, J = 6.6 Hz, $\left.2 \mathrm{H}, \mathrm{CH}_{2} \mathrm{NHCbz}\right), 2.72(\mathrm{t}, J$ $=7.1 \mathrm{~Hz}, 2 \mathrm{H}$, TrizCH${ }_{2}$ ), 1.70 (quin, $J=7.5 \mathrm{~Hz}, 2 \mathrm{H}$, TrizCH $\mathrm{CH}_{2}$ ), 1.52 (quin, $J=7.2 \mathrm{~Hz}, 2 \mathrm{H}, \mathrm{C}_{2} \mathrm{CH}_{2} \mathrm{NHCbz}$ ); ${ }^{13} \mathrm{C}$ NMR (DMSO- $\bar{d}_{6}$, $75 \mathrm{MHz}) \delta(\mathrm{ppm}): 161.8(\mathrm{NHCON}), 158.0\left(\mathrm{OC}_{\mathrm{Ar}}\right), 155.8$ (NHCOO), $147.9\left(\mathrm{C}_{\mathrm{Ar}}\right), 146.6\left(\mathrm{C}_{\mathrm{Ar}}\right), 139.4\left(\mathrm{C}_{\mathrm{Ar}}\right), 139.3\left(\mathrm{C}_{\mathrm{Ar}}\right)$, $138.3\left(\mathrm{C}_{\mathrm{Ar}}\right), 137.1\left(\mathrm{C}_{\mathrm{Ar}}\right), 135.8\left(\mathrm{C}_{\mathrm{Ar}}\right), 135.0\left(\mathrm{C}_{\mathrm{Ar}}\right), 131.6\left(\mathrm{C}_{\mathrm{Ar}}\right), 130.9$ $\left(\mathrm{CH}_{\mathrm{Ar}}\right), 129.9\left(\mathrm{CH}_{\mathrm{Ar}}\right), 128.9\left(\mathrm{CH}_{\mathrm{Ar}}\right), 128.6\left(\mathrm{CH}_{\mathrm{Ar}}\right), 128.0\left(\mathrm{C}_{\mathrm{Ar}}\right)$, $128.0\left(\mathrm{CH}_{\mathrm{Ar}}\right), 127.4\left(\mathrm{CH}_{\mathrm{Ar}}\right), 127.3\left(\mathrm{C}_{\mathrm{Ar}}\right), 127.2\left(\mathrm{CH}_{\mathrm{Ar}}\right), 126.9$ $\left(\mathrm{CH}_{\mathrm{Ar}}\right), 126.7\left(\mathrm{C}_{\mathrm{Ar}}\right), 126.2\left(\mathrm{CH}_{\mathrm{Ar}}\right), 120.9\left(\mathrm{CH}_{\mathrm{Ar}}\right), 119.9\left(\mathrm{CH}_{\mathrm{Ar}}\right)$, $119.5\left(\mathrm{C}_{\mathrm{Ar}}\right), 112.0\left(\mathrm{CH}_{\mathrm{Ar}}\right), 104.3\left(\mathrm{CH}_{\mathrm{Ar}}\right), 67.3\left(\mathrm{NHCOOCH}_{2}\right), 64.9$ $\left(\mathrm{OCH}_{2}\right), 45.0\left(\mathrm{CH}_{2} \mathrm{CH}_{2} \mathrm{NHCON}\right), 42.3\left(\mathrm{OCH}_{2} \underline{\mathrm{CH}}_{2}\right), 39.9$ $\left(\mathrm{CH}_{2} \mathrm{NHCbz}\right), 37.3\left(\mathrm{CH}_{2} \mathrm{CH}_{2} \mathrm{NHCON}\right), 28.7\left(\mathrm{CH}_{2} \mathrm{CH}_{2} \mathrm{NHCbz}\right)$, $25.8\left(\mathrm{TrizCH}_{2} \underline{\mathrm{CH}}_{2}\right), 24.5\left(\mathrm{Triz} \mathrm{CH}_{2}\right)$; HRMS (ES, positive mode) $\mathrm{m} /$ $z$ : calcd for $\mathrm{C}_{48} \mathrm{H}_{45} \mathrm{~N}_{7} \mathrm{O}_{4} \mathrm{~S}$ 815.3254; found 815.3266 (1.56 ppm).

Benzyl-(E)-(4-(1-(4-(4-(2-([4-phenyloxyphenyl]-1-yl)vinyl)-5-phenylthiazol-2-yl)-3-(2-(2-oxoimidazolidin-1-yl)ethoxy)phenyl)-1H1,2,3-triazol-4-yl)butyl)carbamate (18e). According to the general Hantzsch procedure, thioamide $9(183 \mathrm{mg}, 0.34 \mathrm{mmol})$ was reacted with $\alpha$-bromoketone $17 \mathrm{~d}(134 \mathrm{mg}, 0.34 \mathrm{mmol})$ in ${ }^{i} \mathrm{PrOH}(23 \mathrm{~mL})$. After purification of the residue by CCTLC on the Chromatotron $\left(\mathrm{CH}_{2} \mathrm{Cl}_{2} / \mathrm{MeOH}, 96: 4\right)$, 18e $(150 \mathrm{mg}, 52 \%)$ was obtained as a colorless oil. ${ }^{1} \mathrm{H}$ NMR (DMSO- $\left.d_{6}, 400 \mathrm{MHz}\right) \delta(\mathrm{ppm}): 8.74(\mathrm{~s}, 1 \mathrm{H}$, $\mathrm{Ar}), 8.61(\mathrm{~d}, J=8.5 \mathrm{~Hz}, 1 \mathrm{H}, \mathrm{Ar}), 7.85-7.67(\mathrm{~m}, 3 \mathrm{H}, \mathrm{Ar}$, ThiazCH= $\mathrm{CH}), 7.64-7.51(\mathrm{~m}, 5 \mathrm{H}, \mathrm{Ar}), 7.51-7.24(\mathrm{~m}, 9 \mathrm{H}, \mathrm{Ar}), 7.20-7.10(\mathrm{~m}$, $2 \mathrm{H}, \mathrm{Ar}, \operatorname{ThiazC} \underline{\mathrm{H}}=\mathrm{CH}), 7.05(\mathrm{~d}, J=7.7 \mathrm{~Hz}, 2 \mathrm{H}, \mathrm{Ar}), 7.00(\mathrm{~d}, J=8.6$ $\mathrm{Hz}, 2 \mathrm{H}, \mathrm{Ar}), 6.40$ (bs, $1 \mathrm{H}, \mathrm{NHCON}), 5.01$ (s, $2 \mathrm{H}, \mathrm{NHCOOCH}_{2}$ ), $4.49\left(\mathrm{t}, J=5.7 \mathrm{~Hz}, 2 \mathrm{H}, \mathrm{OCH}_{2}\right), 3.66\left(\mathrm{t}, J=5.6 \mathrm{~Hz}, 2 \mathrm{H}, \mathrm{OCH}_{2} \mathrm{C}_{2}\right)$, 3.49 (dd, $\left.J=9.0,6.6 \mathrm{~Hz}, 2 \mathrm{H}, \mathrm{CH}_{2} \mathrm{CH}_{2} \mathrm{NHCON}\right), 3.22(\mathrm{t}, J=7.9 \mathrm{~Hz}$, $2 \mathrm{H}, \mathrm{CH}_{2} \mathrm{C}_{2}{ }_{2} \mathrm{NHCON}$ ), 3.07 (q, $J=6.6 \mathrm{~Hz}, 2 \mathrm{H}, \underline{\mathrm{C}}_{2} \mathrm{NHCbz}$ ), 2.74 $\left(\mathrm{t}, J=7.5 \mathrm{~Hz}, 2 \mathrm{H}, \mathrm{TrizCH}_{2}\right.$ ), 1.69 (quin, $J=7.5 \mathrm{~Hz}, 2 \mathrm{H}$, $\mathrm{TrizCH}_{2} \mathrm{CH}_{2}$ ), 1.53 (quin, $J=7.2 \mathrm{~Hz}, 2 \mathrm{H}, \mathrm{CH}_{2} \mathrm{CH}_{2} \mathrm{NHCbz}$ ); ${ }^{13} \mathrm{C}$ NMR (DMSO- $\left.d_{6}, 75 \mathrm{MHz}\right) \delta(\mathrm{ppm}): 162.1(\mathrm{NHCON}), 158.1\left(\mathrm{C}_{\mathrm{Ar}}\right)$, $156.6\left(\mathrm{OC}_{\mathrm{Ar}}\right), 156.3\left(\mathrm{OC}_{\mathrm{Ar}}\right), 156.1\left(\mathrm{OC}_{\mathrm{Ar}}\right), 156.0(\mathrm{NHCOO}), 148.1$ $\left(\mathrm{C}_{\mathrm{Ar}}\right), 146.7\left(\mathrm{OC}_{\mathrm{Ar}}\right), 138.4\left(\mathrm{C}_{\mathrm{Ar}}\right), 137.3\left(\mathrm{C}_{\mathrm{Ar}}\right), 134.8\left(\mathrm{C}_{\mathrm{Ar}}\right), 132.0$ $\left(\mathrm{C}_{\mathrm{Ar}}\right), 131.6\left(\mathrm{C}_{\mathrm{Ar}}\right), 131.1\left(\mathrm{C}_{\mathrm{Ar}}\right), 130.1\left(\mathrm{C}_{\mathrm{Ar}}\right), 129.4\left(\mathrm{CH}_{\mathrm{Ar}}\right), 129.2$ $\left(\mathrm{CH}_{\mathrm{Ar}}\right), 128.4\left(\mathrm{CH}_{\mathrm{Ar}}\right), 128.3\left(\mathrm{CH}_{\mathrm{Ar}}\right), 127.7\left(\mathrm{CH}_{\mathrm{Ar}}\right), 123.7\left(\mathrm{CH}_{\mathrm{Ar}}\right)$, $120.9\left(\mathrm{CH}_{\mathrm{Ar}}\right), 120.3\left(\mathrm{C}_{\mathrm{Ar}}\right), 118.9\left(\mathrm{CH}_{\mathrm{Ar}}\right), 118.7\left(\mathrm{CH}_{\mathrm{Ar}}\right), 112.0$ $\left(\mathrm{CH}_{\mathrm{Ar}}\right), 104.3\left(\mathrm{CH}_{\mathrm{Ar}}\right), 67.4\left(\mathrm{NHCOOCH}_{2}\right), 65.1\left(\mathrm{OCH}_{2}\right), 45.1$ $\left(\mathrm{CH}_{2} \mathrm{CH}_{2} \mathrm{NHCON}\right), 42.4\left(\mathrm{OCH}_{2} \mathrm{CH}_{2}\right), 40.0\left(\mathrm{CH}_{2} \mathrm{NHCbz}\right), 37.5$ $\left(\mathrm{CH}_{2} \mathrm{CH}_{2} \mathrm{NHCON}\right), 28.9\left(\mathrm{CH}_{2} \mathrm{CH}_{2} \mathrm{NHCbz}\right), 26.0\left(\mathrm{TrizCH}_{2} \mathrm{CH}_{2}\right)$, $24.7\left(\mathrm{TrizCH}_{2}\right)$; HRMS (ES, positive mode) $\mathrm{m} / \mathrm{z}$ : calcd for $\mathrm{C}_{48} \mathrm{H}_{45} \mathrm{~N}_{7} \mathrm{O}_{5} \mathrm{~S}$ 831.3203; found 831.3174 (-3.45 ppm).

1-(2-(5-(4-(4-Ammoniobutyl)-1H-1,2,3-triazol-1-yl)-2-(4,5-diphenylthiazol-2-yl)phenoxy)ethyl)imidazolidin-2-one 2,2,2-Trifluoroacetate (19a). Following the general $\mathrm{Cbz}$ removal procedure, 18a (100 $\mathrm{mg}, 0.14 \mathrm{mmol}), \mathrm{Pd} / \mathrm{C} 10 \%(20 \mathrm{mg})$ and TFA $(1 \mathrm{~mL})$ afforded, after purification, compound 19a (25 mg, 26\%) as a colorless oil. ${ }^{1} \mathrm{H}$ NMR $\left(\mathrm{CD}_{3} \mathrm{OD}, 400 \mathrm{MHz}\right) \delta(\mathrm{ppm}): 8.56(\mathrm{~d}, J=8.6 \mathrm{~Hz}, 1 \mathrm{H}, \mathrm{Ar}), 8.46(\mathrm{~s}$, $1 \mathrm{H}, \mathrm{Ar}), 7.71(\mathrm{~d}, J=8.0 \mathrm{~Hz}, 1 \mathrm{H}, \mathrm{Ar}), 7.59(\mathrm{dd} J=8.6,2.0 \mathrm{~Hz}, 1 \mathrm{H}$, $\mathrm{Ar}), 7.56-7.51(\mathrm{~m}, 2 \mathrm{H}, \mathrm{Ar}), 7.44-7.27(\mathrm{~m}, 8 \mathrm{H}, \mathrm{Ar}), 4.51(\mathrm{t}, J=5.5$ $\left.\mathrm{Hz}, 2 \mathrm{H}, \mathrm{OCH}_{2}\right), 3.76\left(\mathrm{t}, J=5.5 \mathrm{~Hz}, 2 \mathrm{H}, \mathrm{OCH}_{2} \underline{\mathrm{C}}_{2}\right), 3.62(\mathrm{dd}, J=$ 9.3, $\left.6.9 \mathrm{~Hz}, 2 \mathrm{H}, \mathrm{C}_{2} \mathrm{CH}_{2} \mathrm{NHCON}\right), 3.32(\mathrm{dd}, J=9.3,6.9 \mathrm{~Hz}, 2 \mathrm{H}$, $\left.\mathrm{CH}_{2} \mathrm{CH}_{2} \mathrm{NHCON}\right), 3.00\left(\mathrm{q}, J=6.5 \mathrm{~Hz}, 2 \mathrm{H}, \mathrm{CH}_{2} \mathrm{NH}_{3}{ }^{+}\right), 2.86(\mathrm{t}, J=$ $\left.7.2 \mathrm{~Hz}, 2 \mathrm{H}, \quad \operatorname{TrizCH}_{2}\right), 1.95-1.65\left(\mathrm{~m}, 4 \mathrm{H}, \mathrm{TrizCH}_{2} \mathrm{CH}_{2}\right.$, $\left.\mathrm{CH}_{2} \mathrm{CH}_{2} \mathrm{NH}_{3}^{+}\right) ;{ }^{13} \mathrm{C}$ NMR ( $\left.\mathrm{CD}_{3} \mathrm{OD}, 75 \mathrm{MHz}\right) \delta(\mathrm{ppm}): 165.0$ $(\mathrm{NHCON}), 159.9\left(\mathrm{OC}_{\mathrm{Ar}}\right), 157.5\left(\mathrm{C}_{\mathrm{Ar}}\right), 150.6\left(\mathrm{C}_{\mathrm{Ar}}\right), 149.3\left(\mathrm{C}_{\mathrm{Ar}}\right)$, $139.8\left(\mathrm{C}_{\mathrm{Ar}}\right), 136.4\left(\mathrm{C}_{\mathrm{Ar}}\right), 135.8\left(\mathrm{C}_{\mathrm{Ar}}\right), 133.3\left(\mathrm{CH}_{\mathrm{Ar}}\right), 130.6\left(\mathrm{CH}_{\mathrm{Ar}}\right)$, $130.5\left(\mathrm{CH}_{\mathrm{Ar}}\right), 130.3\left(\mathrm{CH}_{\mathrm{Ar}}\right), 129.9\left(\mathrm{CH}_{\mathrm{Ar}}\right), 129.3\left(\mathrm{CH}_{\mathrm{Ar}}\right), 129.3$ $\left(\mathrm{CH}_{\mathrm{Ar}}\right), 129.0\left(\mathrm{CH}_{\mathrm{Ar}}\right), 129.0\left(\mathrm{CH}_{\mathrm{Ar}}\right), 123.7\left(\mathrm{CH}_{\mathrm{Ar}}\right), 121.6\left(\mathrm{CH}_{\mathrm{Ar}}\right)$, $113.6\left(\mathrm{CH}_{\mathrm{Ar}}\right), 105.6\left(\mathrm{CH}_{\mathrm{Ar}}\right), 68.2\left(\mathrm{OCH}_{2}\right), 46.9$ $\left(\mathrm{CH}_{2} \mathrm{CH}_{2} \mathrm{NHCON}\right), 43.9\left(\mathrm{OCH}_{2} \mathrm{CH}_{2}\right), 40.4\left(\mathrm{CH}_{2} \mathrm{NH}_{3}{ }^{+}\right), 39.3$ $\left(\mathrm{CH}_{2} \underline{\mathrm{CH}}_{2} \mathrm{NHCON}\right), 28.0\left(\underline{\mathrm{CH}}_{2} \mathrm{CH}_{2} \mathrm{NH}_{3}^{+}\right), 27.1\left(\mathrm{TrizCH}_{2} \mathrm{CH}_{2}\right)$, $25.6\left(\right.$ Triz $\left.\mathrm{CH}_{2}\right)$; HPLC (gradient A, Agilent): $R_{\mathrm{t}}=9.3 \mathrm{~min}$; HRMS (ES, positive mode) $\mathrm{m} / z$ : calcd for $\mathrm{C}_{32} \mathrm{H}_{33} \mathrm{~N}_{7} \mathrm{O}_{2} \mathrm{~S}$ 579.2416; found 579.242 (0.61 ppm); anal. calcd for $\mathrm{C}_{32} \mathrm{H}_{34} \mathrm{~N}_{7} \mathrm{O}_{2} \mathrm{~S}$.TFA: C, 58.87; $\mathrm{H}$, 4.94; N, 14.13; S, 4.62; found: C, 59.15; H, $5.36 \mathrm{~N}, 14.62$; S, 5.03.
1-(2-(5-(4-(4-Ammoniobutyl)-1H-1,2,3-triazol-1-yl)-2-(4-([1,1'-biphenyl]-4-yl)-5-phenylthiazol-2-yl)phenoxy) ethyl)imidazolidin-2one 2,2,2-Trifluoroacetate (19b). The general $\mathrm{N}$-deprotection procedure described for $12 \mathbf{a}-\mathbf{c}$ was followed with $\mathbf{1 8 b}(100 \mathrm{mg}$, $0.13 \mathrm{mmol}), \mathrm{Pd} / \mathrm{C} 10 \%(20 \mathrm{mg})$, and TFA $(0.8 \mathrm{~mL})$ to give, after workup and purification, compound $\mathbf{1 9 b}(15 \mathrm{mg}, 15 \%)$ as a colorless oil. ${ }^{1} \mathrm{H}$ NMR (DMSO- $\left.d_{6}, 400 \mathrm{MHz}\right) \delta(\mathrm{ppm}): 8.79(\mathrm{~s}, 1 \mathrm{H}, \mathrm{Ar}), 8.57$ $(\mathrm{d}, J=8.6 \mathrm{~Hz}, 1 \mathrm{H}, \mathrm{Ar}), 7.80(\mathrm{~d}, J=8.1 \mathrm{~Hz}, 1 \mathrm{H}, \mathrm{Ar}), 7.77-7.60(\mathrm{~m}$, $\left.10 \mathrm{H}, \mathrm{Ar}, \mathrm{NH}_{3}^{+}\right), 7.54-7.41(\mathrm{~m}, 7 \mathrm{H}, \mathrm{Ar}), 7.37(\mathrm{t}, J=7.5 \mathrm{~Hz}, 1 \mathrm{H}, \mathrm{Ar})$, $6.40(\mathrm{bs}, 1 \mathrm{H}, \mathrm{NHCON}), 4.53\left(\mathrm{t}, J=5.6 \mathrm{~Hz}, 2 \mathrm{H}, \mathrm{OCH}_{2}\right), 3.66(\mathrm{t}, J=$ $\left.5.6 \mathrm{~Hz}, 2 \mathrm{H}, \mathrm{OCH}_{2} \mathrm{CH}_{2}\right), 3.51(\mathrm{dd}, J=9.0,6.7 \mathrm{~Hz}, 2 \mathrm{H}$, $\left.\mathrm{CH}_{2} \mathrm{CH}_{2} \mathrm{NHCON}\right), 3.23\left(\mathrm{t}, J=7.8 \mathrm{~Hz}, 2 \mathrm{H}, \mathrm{CH}_{2} \mathrm{CH}_{2} \mathrm{NHCON}\right)$, $2.85\left(\mathrm{t}, J=7.5 \mathrm{~Hz}, 2 \mathrm{H}, \mathrm{CH}_{2} \mathrm{NH}_{3}^{+}\right), 2.78\left(\mathrm{t}, J=7.2 \mathrm{~Hz}, 2 \mathrm{H}, \mathrm{TrizCH}_{2}\right)$, 1.76 (quin, $J=7.2 \mathrm{~Hz}, 2 \mathrm{H}$, TrizCH $\mathrm{CH}_{2}$ ), 1.63 (quin, $J=7.8 \mathrm{~Hz}, 2 \mathrm{H}$, $\mathrm{CH}_{2} \mathrm{CH}_{2} \mathrm{NH}_{3}{ }^{+}$); ${ }^{13} \mathrm{C}$ NMR (DMSO- $\left.d_{6}, 100 \mathrm{MHz}\right) \delta(\mathrm{ppm}): 162.1$ $(\mathrm{NHCON}), 157.9\left(\mathrm{OC}_{\mathrm{Ar}}\right), 155.8\left(\mathrm{C}_{\mathrm{Ar}}\right), 148.0\left(\mathrm{C}_{\mathrm{Ar}}\right), 147.7\left(\mathrm{C}_{\mathrm{Ar}}\right)$, $139.4\left(\mathrm{C}_{\mathrm{Ar}}\right), 139.4\left(\mathrm{C}_{\mathrm{Ar}}\right), 138.3\left(\mathrm{C}_{\mathrm{Ar}}\right), 133.9\left(\mathrm{C}_{\mathrm{Ar}}\right), 133.7\left(\mathrm{C}_{\mathrm{Ar}}\right), 131.5$ $\left(\mathrm{CH}_{\mathrm{Ar}}\right), 129.3\left(\mathrm{CH}_{\mathrm{Ar}}\right), 129.2\left(\mathrm{CH}_{\mathrm{Ar}}\right), 129.1\left(\mathrm{CH}_{\mathrm{Ar}}\right), 129.0\left(\mathrm{CH}_{\mathrm{Ar}}\right)$, $128.8\left(\mathrm{CH}_{\mathrm{Ar}}\right), 128.5\left(\mathrm{CH}_{\mathrm{Ar}}\right), 127.6\left(\mathrm{CH}_{\mathrm{Ar}}\right), 126.5\left(\mathrm{CH}_{\mathrm{Ar}}\right), 126.5$ $\left(\mathrm{CH}_{\mathrm{Ar}}\right), 121.1\left(\mathrm{CH}_{\mathrm{Ar}}\right), 120.4\left(\mathrm{C}_{\mathrm{Ar}}\right), 112.1\left(\mathrm{CH}_{\mathrm{Ar}}\right), 104.3\left(\mathrm{CH}_{\mathrm{Ar}}\right)$, $67.4\left(\mathrm{OCH}_{2}\right), 45.1\left(\mathrm{CH}_{2} \mathrm{CH}_{2} \mathrm{NHCON}\right), 42.4\left(\mathrm{OCH}_{2} \mathrm{CH}_{2}\right), 38.6$ $\left(\mathrm{CH}_{2} \mathrm{NH}_{3}{ }^{+}\right), 37.5\left(\mathrm{CH}_{2} \underline{\mathrm{C}}{ }_{2} \mathrm{NHCON}\right), 26.5\left(\underline{\mathrm{CH}}_{2} \mathrm{CH}_{2} \mathrm{NH}_{3}{ }^{+}\right), 25.5$ $\left(\mathrm{TrizCH}_{2} \mathrm{CH}_{2}\right)$, $24.4\left(\mathrm{Triz} \mathrm{CH}_{2}\right)$; HPLC (gradient A, Agilent): $R_{\mathrm{t}}=$ $9.3 \mathrm{~min}$; HRMS (ES, positive mode) $\mathrm{m} / \mathrm{z}$ : calcd for $\mathrm{C}_{38} \mathrm{H}_{37} \mathrm{~N}_{7} \mathrm{O}_{2} \mathrm{~S}$ 655.2729; found $655.2748(2.87 \mathrm{ppm})$; anal. calcd for $\mathrm{C}_{38} \mathrm{H}_{38} \mathrm{~N}_{7} \mathrm{O}_{2} \mathrm{~S}$. TFA: C, 62.41; H, 4.98; N, 12.74; S, 4.16; found: C, 62.36; H, 5.06; $\mathrm{N}, 12.37$; S, 4.25 .

1-(2-(5-(4-(4-Ammoniobutyl)-1H-1,2,3-triazol-1-yl)-2-(4-([4-phenyloxyphenyl]-1-yl)-5-phenylthiazol-2-yl) phenoxy)ethyl)imidazolidin-2-one 2,2,2-Trifluoroacetate (19c). Following the general $\mathrm{Cbz}$ deprotection procedure, $18 \mathrm{c}(120 \mathrm{mg}, 0.15 \mathrm{mmol})$, $\mathrm{Pd} / \mathrm{C} 10 \%(24 \mathrm{mg})$, and TFA $(0.9 \mathrm{~mL})$ were reacted. Workup and purification yielded $19 \mathrm{c}(44 \mathrm{mg}, 37 \%)$ as a colorless oil. ${ }^{1} \mathrm{H}$ NMR $\left(\right.$ DMSO- $\left.d_{6}, 400 \mathrm{MHz}\right) \delta(\mathrm{ppm}): 8.78(\mathrm{~s}, 1 \mathrm{H}, \mathrm{Ar}), 8.53(\mathrm{~d}, J=8.6 \mathrm{~Hz}$, $1 \mathrm{H}, \mathrm{Ar}), 7.79(\mathrm{~d}, J=2.1 \mathrm{~Hz}, 1 \mathrm{H}, \mathrm{Ar}), 7.83-7.72\left(\mathrm{~m}, 3 \mathrm{H}, \mathrm{NH}_{3}^{+}\right), 7.71$ (dd, $J=8.6,2.0 \mathrm{~Hz}, 1 \mathrm{H}, \mathrm{Ar}), 7.56(\mathrm{~d}, J=8.7 \mathrm{~Hz}, 2 \mathrm{H}, \mathrm{Ar}), 7.50-7.32$ (m, 7H, Ar), $7.17(\mathrm{t}, J=7.4 \mathrm{~Hz}, 1 \mathrm{H}, \mathrm{Ar}), 7.06(\mathrm{~d}, J=7.9 \mathrm{~Hz}, 2 \mathrm{H}, \mathrm{Ar})$, $6.98(\mathrm{~d}, J=8.7 \mathrm{~Hz}, 2 \mathrm{H}, \mathrm{Ar}), 6.39(\mathrm{bs}, 1 \mathrm{H}, \mathrm{NHCON}), 4.51(\mathrm{t}, J=5.6$ $\left.\mathrm{Hz}, 2 \mathrm{H}, \mathrm{OCH}_{2}\right), 3.65\left(\mathrm{t}, J=5.6 \mathrm{~Hz}, 2 \mathrm{H}, \mathrm{OCH}_{2} \mathrm{CH}_{2}\right), 3.50(\mathrm{dd}, J=$ 9.0, $\left.6.7 \mathrm{~Hz}, 2 \mathrm{H}, \mathrm{CH}_{2} \mathrm{CH}_{2} \mathrm{NHCON}\right), 3.22(\mathrm{t}, J=7.9 \mathrm{~Hz}, 2 \mathrm{H}$, $\left.\mathrm{CH}_{2} \mathrm{CH}_{2} \mathrm{NHCON}\right), 2.91-2.80\left(\mathrm{~m}, 2 \mathrm{H}, \mathrm{CH}_{2} \mathrm{NH}_{3}{ }^{+}\right), 2.77(\mathrm{t}, J=7.2$ $\mathrm{Hz}, 2 \mathrm{H}$, TrizCH${ }_{2}$ ), 1.76 (quin, $J=7.2 \mathrm{~Hz}, 2 \mathrm{H}$, TrizCH${ }_{2} \underline{\mathrm{C}}_{2}$ ), 1.64 (quin, $J=8.1 \mathrm{~Hz}, 2 \mathrm{H}, \underline{\mathrm{C}}_{2} \mathrm{CH}_{2} \mathrm{NH}_{3}{ }^{+}$); ${ }^{13} \mathrm{C}$ NMR (DMSO-d $d_{6}, 100$ $\mathrm{MHz}) \delta(\mathrm{ppm}): 162.1(\mathrm{NHCON}), 158.1\left(\mathrm{CF}_{3} \mathrm{COO}^{-}\right), 157.8\left(\mathrm{C}_{\mathrm{Ar}}\right)$, $156.5\left(\mathrm{OC}_{\mathrm{Ar}}\right), 156.2\left(\mathrm{OC}_{\mathrm{Ar}}\right), 155.5\left(\mathrm{OC}_{\mathrm{Ar}}\right), 147.9\left(\mathrm{C}_{\mathrm{Ar}}\right), 147.7\left(\mathrm{C}_{\mathrm{Ar}}\right)$, $138.3\left(\mathrm{C}_{\mathrm{Ar}}\right), 133.3\left(\mathrm{C}_{\mathrm{Ar}}\right), 131.5\left(\mathrm{C}_{\mathrm{Ar}}\right), 130.4\left(\mathrm{CH}_{\mathrm{Ar}}\right), 130.1\left(\mathrm{CH}_{\mathrm{Ar}}\right)$, $129.8\left(\mathrm{CH}_{\mathrm{Ar}}\right), 129.2\left(\mathrm{CH}_{\mathrm{Ar}}\right), 129.0\left(\mathrm{CH}_{\mathrm{Ar}}\right), 128.8\left(\mathrm{CH}_{\mathrm{Ar}}\right), 128.3$ $\left(\mathrm{C}_{\mathrm{Ar}}\right), 123.8\left(\mathrm{CH}_{\mathrm{Ar}}\right), 121.1\left(\mathrm{C}_{\mathrm{Ar}}\right), 120.4\left(\mathrm{CH}_{\mathrm{Ar}}\right), 119.0\left(\mathrm{CH}_{\mathrm{Ar}}\right), 118.1$ $\left(\mathrm{CH}_{\mathrm{Ar}}\right), 115.8\left(\mathrm{CF}_{3} \mathrm{COO}^{-}\right), 112.1\left(\mathrm{CH}_{\mathrm{Ar}}\right), 104.3\left(\mathrm{CH}_{\mathrm{Ar}}\right), 67.3$ $\left(\mathrm{OCH}_{2}\right), 45.1\left(\underline{\mathrm{CH}}_{2} \mathrm{CH}_{2} \mathrm{NHCON}\right), 42.4 \quad\left(\mathrm{OCH}_{2} \underline{\mathrm{CH}}_{2}\right), 38.6$ $\left(\mathrm{CH}_{2} \mathrm{NH}_{3}^{+}\right), 37.5\left(\mathrm{CH}_{2} \mathrm{CH}_{2} \mathrm{NHCON}\right), 26.5\left(\mathrm{CH}_{2} \mathrm{CH}_{2} \mathrm{NH}_{3}{ }^{+}\right), 25.5$ $\left(\right.$ TrizCH $\left.{ }_{2} \mathrm{CH}_{2}\right), 24.4\left(\mathrm{Triz}_{2}\right)$; HPLC (gradient A, Agilent): $R_{\mathrm{t}}=$ $9.8 \mathrm{~min}$; HRMS (ES, positive mode) $\mathrm{m} / z$ : calcd for $\mathrm{C}_{38} \mathrm{H}_{37} \mathrm{~N}_{7} \mathrm{O}_{3} \mathrm{~S}$ 671.2679; found $671.2673(-0.81 \mathrm{ppm})$; anal. calcd for $\mathrm{C}_{38} \mathrm{H}_{38} \mathrm{~N}_{7} \mathrm{O}_{3} \mathrm{~S}$.TFA: C, 61.14; $\mathrm{H}, 4.87 ; \mathrm{N}, 12.48 ; \mathrm{S}, 4.08$; found: C, 61.55; H, 4.99; N, 12.12; S, 4.34 .

1-(2-(2-(4-(2-([1,1'-Biphenyl]-4-yl)ethyl)-5-phenyl-thiazol-2-yl)-5(4-(4-ammoniobutyl)-1 $\mathrm{H}$-1,2,3-triazol-1-yl)phenoxy)ethyl)imidazolidin-2-one 2,2,2-Trifluoroacetate (19d). Following the general hydrogenation procedure, a solution of $18 \mathrm{~d}(91 \mathrm{mg}, 0.11$ $\mathrm{mmol}), \mathrm{Pd} / \mathrm{C} 10 \%(18 \mathrm{mg})$, and TFA $(0.7 \mathrm{~mL})$ was reacted to give, after purification, 19d $(14 \mathrm{mg}, 16 \%)$ as a colorless oil. ${ }^{1} \mathrm{H}$ NMR $\left(\right.$ DMSO $\left._{6}, 400 \mathrm{MHz}\right) \delta(\mathrm{ppm}): 8.78(\mathrm{~s}, 1 \mathrm{H}, \mathrm{Ar}), 8.54(\mathrm{~d}, J=8.6 \mathrm{~Hz}$, $1 \mathrm{H}, \mathrm{Ar}), 7.78(\mathrm{~d}, J=2.1 \mathrm{~Hz}, 1 \mathrm{H}, \mathrm{Ar}), 7.72(\mathrm{dd}, J=8.5,2.0 \mathrm{~Hz}, 1 \mathrm{H}$, Ar), 7.73-7.65 (m, 3H, $\left.\mathrm{NH}_{3}^{+}\right), 7.62(\mathrm{~d}, J=7.2 \mathrm{~Hz}, 2 \mathrm{H}, \mathrm{Ar}), 7.54$ (d, $J=8.2 \mathrm{~Hz}, 2 \mathrm{H}, \mathrm{Ar}), 7.49-7.38(\mathrm{~m}, 7 \mathrm{H}, \mathrm{Ar}), 7.33(\mathrm{tt}, J=7.4,1.3 \mathrm{~Hz}$, $1 \mathrm{H}, \mathrm{Ar}), 7.26$ (d, $J=8.2 \mathrm{~Hz}, 2 \mathrm{H}, \mathrm{Ar}), 6.39$ (bs, $1 \mathrm{H}, \mathrm{NHCON}), 4.50$ $\left(\mathrm{t}, J=5.6 \mathrm{~Hz}, 2 \mathrm{H}, \mathrm{OCH}_{2}\right), 3.65\left(\mathrm{t}, J=5.6 \mathrm{~Hz}, 2 \mathrm{H}, \mathrm{OCH}_{2} \mathrm{CH}_{2}\right), 3.49$ (dd, $\left.J=8.9,6.7 \mathrm{~Hz}, 2 \mathrm{H}, \mathrm{CH}_{2} \mathrm{CH}_{2} \mathrm{NHCON}\right), 3.21(\mathrm{t}, J=7.9 \mathrm{~Hz}, 2 \mathrm{H}$, $\mathrm{CH}_{2} \mathrm{CH}_{2} \mathrm{NHCON}$ ), 3.16-3.12 (m, 4H, Thiaz $\left.\underline{\mathrm{H}}_{2} \mathrm{C}_{2}\right), 2.85$ (t, $J=$ 
$\left.7.5 \mathrm{~Hz}, 2 \mathrm{H}, \mathrm{CH}_{2} \mathrm{NH}_{3}^{+}\right), 2.78\left(\mathrm{t}, J=7.2 \mathrm{~Hz}, 2 \mathrm{H}, \mathrm{TrizCH}_{2}\right), 1.76$ (quin, $J=7.6 \mathrm{~Hz}, 2 \mathrm{H}$, Triz $\mathrm{CH}_{2} \mathrm{CH}_{2}$ ), 1.63 (quin, $J=7.5 \mathrm{~Hz}, 2 \mathrm{H}$, $\mathrm{C}_{2} \mathrm{CH}_{2} \mathrm{NH}_{3}{ }^{+}$); ${ }^{13} \mathrm{C}$ NMR (DMSO-d $\left.d_{6}, 100 \mathrm{MHz}\right) \delta(\mathrm{ppm}): 162.1$ $(\mathrm{NHCON}), 157.4\left(\mathrm{C}_{\mathrm{Ar}}\right), 155.6\left(\mathrm{OC}_{\mathrm{Ar}}\right), 150.1\left(\mathrm{C}_{\mathrm{Ar}}\right), 147.7\left(\mathrm{C}_{\mathrm{Ar}}\right)$, $140.7\left(\mathrm{C}_{\mathrm{Ar}}\right), 140.1\left(\mathrm{C}_{\mathrm{Ar}}\right), 138.1\left(\mathrm{C}_{\mathrm{Ar}}\right), 137.9\left(\mathrm{C}_{\mathrm{Ar}}\right), 133.4\left(\mathrm{C}_{\mathrm{Ar}}\right), 131.4$ $\left(\mathrm{C}_{\mathrm{Ar}}\right), 129.0\left(\mathrm{CH}_{\mathrm{Ar}}\right), 128.9\left(\mathrm{CH}_{\mathrm{Ar}}\right), 128.9\left(\mathrm{CH}_{\mathrm{Ar}}\right), 128.9\left(\mathrm{CH}_{\mathrm{Ar}}\right)$, $128.8\left(\mathrm{CH}_{\mathrm{Ar}}\right), 128.0\left(\mathrm{CH}_{\mathrm{Ar}}\right), 127.2\left(\mathrm{CH}_{\mathrm{Ar}}\right), 126.6\left(\mathrm{CH}_{\mathrm{Ar}}\right), 126.5$ $\left(\mathrm{CH}_{\mathrm{Ar}}\right), 121.3\left(\mathrm{C}_{\mathrm{Ar}}\right), 120.4\left(\mathrm{CH}_{\mathrm{Ar}}\right), 112.1\left(\mathrm{CH}_{\mathrm{Ar}}\right), 104.3\left(\mathrm{CH}_{\mathrm{Ar}}\right)$, $67.4\left(\mathrm{OCH}_{2}\right), 45.2\left(\mathrm{CH}_{2} \mathrm{CH}_{2} \mathrm{NHCON}\right), 42.4\left(\mathrm{OCH}_{2} \mathrm{CH}_{2}\right), 38.7$ $\left(\mathrm{CH}_{2} \mathrm{NH}_{3}^{+}\right)$, $37.5\left(\mathrm{CH}_{2} \mathrm{CH}_{2} \mathrm{NHCON}\right), 34.6\left(\mathrm{Thiaz} \mathrm{CH}_{2} \mathrm{CH}_{2}\right), 31.2$ (ThiazCH $\left.\mathrm{CH}_{2}\right), 26.5\left(\mathrm{C}_{2} \mathrm{CH}_{2} \mathrm{NH}_{3}^{+}\right), 25.6\left(\operatorname{Triz}_{2} \mathrm{CH}_{2} \mathrm{CH}_{2}\right), 24.4$ $\left(\right.$ Triz $\left.\mathrm{CH}_{2}\right)$; HPLC (gradient A, Agilent): $R_{\mathrm{t}}=9.8 \mathrm{~min}$; HRMS (ES, positive mode) $\mathrm{m} / z$ : calcd for $\mathrm{C}_{40} \mathrm{H}_{41} \mathrm{~N}_{7} \mathrm{O}_{2} \mathrm{~S}$ 683.3042; found 683.3050 (1.06 ppm); anal. calcd for $\mathrm{C}_{40} \mathrm{H}_{42} \mathrm{~N}_{7} \mathrm{O}_{2}$ S.TFA: C, 63.22; H, 5.31; N, 12.29; S, 4.02; found: C, 63.40; H, 5.64; N, 12.50; S, 3.93. 1-(2-(2-(4-(2-([4-Phenyloxyphenyl]-1-yl)ethyl)-5-phenyl-thiazol2-yl)-5-(4-(4-ammoniobutyl)-1H-1,2,3-triazol-1-yl)phenoxy)ethyl)imidazolidin-2-one 2,2,2-Trifluoroacetate (19e). Following the general $\mathrm{Cbz}$ deprotection procedure, reaction of $18 \mathrm{e}(80 \mathrm{mg}, 0.10$ $\mathrm{mmol}), \mathrm{Pd} / \mathrm{C} 10 \%(16 \mathrm{mg})$, and TFA $(0.6 \mathrm{~mL})$ afforded $19 \mathrm{e}(20 \mathrm{mg}$, $26 \%$ ) as a colorless oil. ${ }^{1} \mathrm{H}$ NMR (DMSO- $\left.d_{6}, 400 \mathrm{MHz}\right) \delta(\mathrm{ppm})$ : $8.78(\mathrm{~s}, 1 \mathrm{H}, \mathrm{Ar}), 8.56-8.50$ (m, 1H, Ar), 7.77 (d, J = 2.0 Hz, 1H, Ar), 7.81-7.64 (m, 4H, Ar, $\left.\mathrm{NH}_{3}^{+}\right), 7.62(\mathrm{~d}, J=7.2 \mathrm{~Hz}, 1 \mathrm{H}, \mathrm{Ar}), 7.54(\mathrm{~d}, J$ $=8.1 \mathrm{~Hz}, 1 \mathrm{H}, \mathrm{Ar}), 7.50-7.31(\mathrm{~m}, 7 \mathrm{H}, \mathrm{Ar}), 7.26(\mathrm{~d}, J=7.9 \mathrm{~Hz}, 1 \mathrm{H}$, $\mathrm{Ar}), 7.16(\mathrm{~d}, J=8.5 \mathrm{~Hz}, 1 \mathrm{H}, \mathrm{Ar}), 7.10(\mathrm{t}, J=7.4 \mathrm{~Hz}, 1 \mathrm{H}, \mathrm{Ar}), 6.94(\mathrm{~d}$, $J=8.0 \mathrm{~Hz}, 1 \mathrm{H}, \mathrm{Ar}), 6.90(\mathrm{~d}, J=8.5 \mathrm{~Hz}, 1 \mathrm{H}, \mathrm{Ar}), 6.39(\mathrm{bs}, 1 \mathrm{H}$, $\mathrm{NHCON}), 4.49\left(\mathrm{t}, J=5.7 \mathrm{~Hz}, 2 \mathrm{H}, \mathrm{OCH}_{2}\right), 3.64(\mathrm{t}, J=5.7 \mathrm{~Hz}, 2 \mathrm{H}$, $\left.\mathrm{OCH}_{2} \mathrm{CH}_{2}\right), 3.48\left(\mathrm{dd}, J=9.0,6.6 \mathrm{~Hz}, 2 \mathrm{H}, \mathrm{CH}_{2} \mathrm{CH}_{2} \mathrm{NHCON}\right), 3.21$ $\left(\mathrm{t}, J=7.9 \mathrm{~Hz}, 2 \mathrm{H}, \mathrm{CH}_{2} \mathrm{C}_{2} \mathrm{NHCON}_{2}\right), 3.15-3.06(\mathrm{~m}, 4 \mathrm{H}$, Thiaz $\left.\underline{\mathrm{H}}_{2} \mathrm{CH}_{2}\right), 2.85\left(\mathrm{t}, J=7.5 \mathrm{~Hz}, 2 \mathrm{H}, \mathrm{CH}_{2} \mathrm{NH}_{3}{ }^{+}\right), 2.78(\mathrm{t}, J=$ $7.2 \mathrm{~Hz}, 2 \mathrm{H}$, Triz $\mathrm{CH}_{2}$ ), 1.75 (quin, $J=7.4 \mathrm{~Hz}, 2 \mathrm{H}$, TrizC $\mathrm{CH}_{2} \mathrm{CH}_{2}$ ), 1.64 (quin, $J=7.0 \mathrm{~Hz}, 2 \mathrm{H}, \mathrm{C}_{2} \mathrm{CH}_{2} \mathrm{NH}_{3}{ }^{+}$); ${ }^{13} \mathrm{C}$ NMR (DMSO-d $100 \mathrm{MHz}) \delta(\mathrm{ppm}): 162.1(\mathrm{NHCON}), 157.3\left(\mathrm{C}_{\mathrm{Ar}}\right), 157.1\left(\mathrm{C}_{\mathrm{Ar}}\right)$, $155.6\left(\mathrm{OC}_{\mathrm{Ar}}\right), 154.6\left(\mathrm{C}_{\mathrm{Ar}}\right), 150.0\left(\mathrm{C}_{\mathrm{Ar}}\right), 147.7\left(\mathrm{C}_{\mathrm{Ar}}\right), 140.7\left(\mathrm{C}_{\mathrm{Ar}}\right)$, $138.1\left(\mathrm{C}_{\mathrm{Ar}}\right), 137.9\left(\mathrm{C}_{\mathrm{Ar}}\right), 136.6\left(\mathrm{C}_{\mathrm{Ar}}\right), 133.4\left(\mathrm{C}_{\mathrm{Ar}}\right), 131.4\left(\mathrm{CH}_{\mathrm{Ar}}\right)$, $129.9\left(\mathrm{CH}_{\mathrm{Ar}}\right), 129.8\left(\mathrm{CH}_{\mathrm{Ar}}\right), 129.0\left(\mathrm{CH}_{\mathrm{Ar}}\right), 129.0\left(\mathrm{CH}_{\mathrm{Ar}}\right), 128.9$ $\left(\mathrm{CH}_{\mathrm{Ar}}\right), 128.9\left(\mathrm{CH}_{\mathrm{Ar}}\right), 128.9\left(\mathrm{CH}_{\mathrm{Ar}}\right), 128.0\left(\mathrm{CH}_{\mathrm{Ar}}\right), 126.6\left(\mathrm{CH}_{\mathrm{Ar}}\right)$, $126.5\left(\mathrm{CH}_{\mathrm{Ar}}\right), 123.1\left(\mathrm{CH}_{\mathrm{Ar}}\right), 121.3\left(\mathrm{C}_{\mathrm{Ar}}\right), 118.8\left(\mathrm{CH}_{\mathrm{Ar}}\right), 118.1$ $\left(\mathrm{CH}_{\mathrm{Ar}}\right), 112.1\left(\mathrm{CH}_{\mathrm{Ar}}\right), 104.3\left(\mathrm{CH}_{\mathrm{Ar}}\right), 67.4\left(\mathrm{OCH}_{2}\right), 45.2$ $\left(\mathrm{CH}_{2} \mathrm{CH}_{2} \mathrm{NHCON}\right), 42.4\left(\mathrm{OCH}_{2} \mathrm{CH}_{2}\right), 38.7\left(\mathrm{CH}_{2} \mathrm{NH}_{3}^{+}\right), 37.5$ $\left(\mathrm{CH}_{2} \mathrm{CH}_{2} \mathrm{NHCON}\right), \quad 34.6\left(\underline{\mathrm{CH}}_{2} \mathrm{CH}_{2} \mathrm{PhOPh}\right), \quad 31.2$ $\left(\mathrm{CH}_{2} \underline{\mathrm{CH}}_{2} \mathrm{PhOPh}\right), 26.5\left(\underline{\mathrm{CH}}_{2} \mathrm{CH}_{2} \mathrm{NH}_{3}{ }^{+}\right), 25.6\left(\mathrm{TrizCH}_{2} \underline{\mathrm{CH}}_{2}\right), 24.4$ $\left(\right.$ Triz $\mathrm{CH}_{2}$ ); HPLC (gradient A, Agilent): $R_{\mathrm{t}}=9.7 \mathrm{~min}$; HRMS (ES, positive mode) $\mathrm{m} / z$ : calcd for $\mathrm{C}_{40} \mathrm{H}_{41} \mathrm{~N}_{7} \mathrm{O}_{3} \mathrm{~S}$ 699.2992; found $699.2993(0.17 \mathrm{ppm})$; anal. calcd for $\mathrm{C}_{40} \mathrm{H}_{42} \mathrm{~N}_{7} \mathrm{O}_{3}$ S.TFA: C, 61.98; H, 5.20; N, 12.05; S, 3.94; found: C, 62.23; H, 5.34; N, 11.68; S, 3.50 .

1-(3-(2-Bromo)acetylphenyl)-2-bromoethan-1-one (20). Following the general procedure described for the synthesis $\alpha$-bromomethylketones $17 \mathrm{a}-\mathbf{e}, p$-toluensulfonic acid $(761 \mathrm{mg}, 4.00 \mathrm{mmol})$ and NBS (713 mg, $4.00 \mathrm{mmol}$ ) were successively added to a solution of commercially available diacetyl benzene $(250 \mathrm{mg}, 1.54 \mathrm{mmol})$ in $\mathrm{CH}_{3} \mathrm{CN}(20 \mathrm{~mL})$ and stirred at room temperature overnight. After the workup, the residue was purified by flash column chromatography (hexane/EtOAc, 90:10) to give $\mathbf{2 0}(366 \mathrm{mg}, \mathbf{7 4 \%})$ as a white solid. ${ }^{51}$ m.p.: $87-88{ }^{\circ} \mathrm{C} ;{ }^{1} \mathrm{H}$ NMR $\left(\mathrm{CDCl}_{3}, 400 \mathrm{MHz}\right) \delta$ (ppm): $8.55(\mathrm{t}, J=$ $1.8 \mathrm{~Hz}, 1 \mathrm{H}, \mathrm{Ar}), 7.20(\mathrm{dd}, J=7.8,1.8 \mathrm{~Hz}, 2 \mathrm{H}, \mathrm{Ar}), 7.64(\mathrm{t}, J=7.8 \mathrm{~Hz}$, $1 \mathrm{H}, \mathrm{Ar}), 4.78$ (s, $\left.4 \mathrm{H}, \mathrm{BrCH}_{2} \mathrm{CO}\right)$.

Dibenzyl-((((1,3-phenylenebis(thiazole-4,2-diyl))bis(3-(2-(2-oxoimidazolidin-1-yl)ethoxy)-4,1-phenylene)) bis (1 H-1,2,3-triazole-1,4diyl))bis(butane-4,1-diyl))dicarbamate (21). Following the general procedure of Hantzsch synthesis, $9(100 \mathrm{mg}, 0.19 \mathrm{mmol})$ was reacted with $\alpha$-bromoketone $20(30 \mathrm{mg}, 0.09 \mathrm{mmol})$ in ${ }^{i} \mathrm{PrOH}(15 \mathrm{~mL})$. After the workup, the residue was purified by CCTLC on the Chromatotron $\left(\mathrm{CH}_{2} \mathrm{Cl}_{2} / \mathrm{MeOH}, 96: 4\right)$ to give $21(68 \mathrm{mg}, 30 \%)$ as a pink oil. ${ }^{1} \mathrm{H}$ NMR (DMSO- $\left.d_{6}, 400 \mathrm{MHz}\right) \delta(\mathrm{ppm}): 8.75$ (s, $\left.2 \mathrm{H}, \mathrm{Ar}\right)$, 8.68 (d, $J=8.5 \mathrm{~Hz}, 2 \mathrm{H}, \mathrm{Ar}$ ), 8.37 (s, $2 \mathrm{H}, \mathrm{Ar}), 8.12$ (dd, $J=7.6,1.7$ $\mathrm{Hz}, 2 \mathrm{H}, \mathrm{Ar}), 7.79$ (d, $J=2.0 \mathrm{~Hz}, 2 \mathrm{H}, \mathrm{Ar}), 7.75$ (dd, $J=8.7,1.8 \mathrm{~Hz}$, $2 \mathrm{H}, \mathrm{Ar}), 7.60(\mathrm{t}, J=7.7 \mathrm{~Hz}, 1 \mathrm{H}, \mathrm{Ar}), 7.46-7.10(\mathrm{~m}, 12 \mathrm{H}, \mathrm{Ar}$, $\mathrm{NHCbz}), 6.42(\mathrm{~s}, 2 \mathrm{H}, \mathrm{NHCON}), 5.01\left(\mathrm{~s}, 4 \mathrm{H}, \mathrm{NHCOOCH}_{2}\right), 4.52$ $\left(\mathrm{t}, J=5.6 \mathrm{~Hz}, 4 \mathrm{H}, \mathrm{OCH}_{2}\right), 3.69\left(\mathrm{t}, J=5.6 \mathrm{~Hz}, 4 \mathrm{H}, \mathrm{OCH}_{2} \underline{\mathrm{H}}_{2}\right), 3.53$ (dd, $\left.J=9.0,6.7 \mathrm{~Hz}, 4 \mathrm{H}, \mathrm{CH}_{2} \mathrm{CH}_{2} \mathrm{NHCON}\right), 3.25(\mathrm{t}, J=7.9 \mathrm{~Hz}, 4 \mathrm{H}$, $\left.\mathrm{CH}_{2} \mathrm{CH}_{2} \mathrm{NHCON}\right), 3.07\left(\mathrm{q}, J=6.5 \mathrm{~Hz}, 4 \mathrm{H}, \mathrm{CH}_{2} \mathrm{NHCbz}\right), 2.74(\mathrm{t}, J$ $=7.1 \mathrm{~Hz}, 4 \mathrm{H}$, TrizCH${ }_{2}$ ), 1.70 (quin, $J=7.6 \mathrm{~Hz}, 4 \mathrm{H}$, TrizCH $\mathrm{CH}_{2}$ ), 1.52 (quin, $J=7.2 \mathrm{~Hz}, 4 \mathrm{H}, \mathrm{CH}_{2} \mathrm{CH}_{2} \mathrm{NHCbz}$ ); ${ }^{13} \mathrm{C}$ NMR (DMSO- $d_{6}$, $100 \mathrm{MHz}) \delta(\mathrm{ppm}): 162.1(\mathrm{NHCON}), 160.2\left(\mathrm{C}_{\mathrm{Ar}}\right), 156.1\left(\mathrm{OC}_{\mathrm{Ar}}\right)$, 155.9 (NHCOO), $153.3\left(\mathrm{C}_{\mathrm{Ar}}\right), 148.1\left(\mathrm{C}_{\mathrm{Ar}}\right), 138.3\left(\mathrm{C}_{\mathrm{Ar}}\right), 137.3$ $\left(\mathrm{CH}_{\mathrm{Ar}}\right), 134.7\left(\mathrm{C}_{\mathrm{Ar}}\right), 129.3\left(\mathrm{CH}_{\mathrm{Ar}}\right), 128.3\left(\mathrm{CH}_{\mathrm{Ar}}\right), 127.7\left(\mathrm{CH}_{\mathrm{Ar}}\right)$, 126.0 $\left(\mathrm{C}_{\mathrm{Ar}}\right), 123.7\left(\mathrm{C}_{\mathrm{Ar}}\right), 121.1\left(\mathrm{CH}_{\mathrm{Ar}}\right), 120.3\left(\mathrm{CH}_{\mathrm{Ar}}\right), 116.4\left(\mathrm{CH}_{\mathrm{Ar}}\right)$, $112.1\left(\mathrm{CH}_{\mathrm{Ar}}\right), 104.3\left(\mathrm{CH}_{\mathrm{Ar}}\right), 67.6\left(\mathrm{OCH}_{2}\right), 65.1\left(\mathrm{NHCOOCH}_{2}\right)$, $45.3\left(\mathrm{CH}_{2} \mathrm{CH}_{2} \mathrm{NHCON}\right), \quad 42.4\left(\mathrm{OCH}_{2} \mathrm{CH}_{2}\right), 37.6$ $\left(\mathrm{CH}_{2} \mathrm{CH}_{2} \mathrm{NHCON}\right), 28.9\left(\mathrm{CH}_{2} \mathrm{CH}_{2} \mathrm{NHCbz}\right), 26.0\left(\mathrm{TrizCH}_{2} \mathrm{CH}_{2}\right)$, $24.7\left(\mathrm{Triz}_{2}\right)$; HRMS (ES, positive mode) $\mathrm{m} / z$ : calcd for $\mathrm{C}_{62} \mathrm{H}_{64} \mathrm{~N}_{14} \mathrm{O}_{8} \mathrm{~S}_{2}$ 1196.4473; found 1196.4482 (0.72 ppm).

1,1'-(((1,3-Phenylenebis(thiazole-4,2-diyl))bis(5-(4-(4-ammoniobutyl)-1H-1,2,3-triazol-1-yl)-2,1-phenylene)) bis(oxy))bis(ethane2,1-diyl))bis(imidazolidin-2-one)bis(2,2,2-trifluoroacetate) (22). Following the general $\mathrm{Cbz}$ removal procedure, 21 (120 mg, 0.11 $\mathrm{mmol}), \mathrm{Pd} / \mathrm{C} 10 \%(24 \mathrm{mg})$, and TFA $(1.0 \mathrm{~mL})$ reacted to gave, after workup and purification, compound $22(22 \mathrm{mg}, 19 \%)$ as a colorless oil. ${ }^{1} \mathrm{H}$ NMR (DMSO- $\left.d_{6}, 400 \mathrm{MHz}\right) \delta$ (ppm): 8.81 (s, 2H, Ar), 8.75 (s, $1 \mathrm{H}, \mathrm{Ar}), 8.69$ (d, $J=8.5 \mathrm{~Hz}, 2 \mathrm{H}, \mathrm{Ar}), 8.40$ (s, 2H, Ar), 8.13 (dd, $J$ $=7.8,1.7 \mathrm{~Hz}, 2 \mathrm{H}, \mathrm{Ar}), 7.94-7.67\left(\mathrm{~m}, 10 \mathrm{H}, \mathrm{Ar}, \mathrm{NH}_{3}^{+}\right), 7.62(\mathrm{t}, J=7.7$ $\mathrm{Hz}, 1 \mathrm{H}, \mathrm{Ar}), 6.42(\mathrm{bs}, 2 \mathrm{H}, \mathrm{NHCON}), 4.54(\mathrm{t}, J=5.7 \mathrm{~Hz}, 4 \mathrm{H}$, $\left.\mathrm{OCH}_{2}\right), 3.69\left(\mathrm{t}, J=5.6 \mathrm{~Hz}, 4 \mathrm{H}, \mathrm{OCH}_{2} \mathrm{CH}_{2}\right), 3.53(\mathrm{dd}, J=8.9,6.7$ $\left.\mathrm{Hz}, \quad 4 \mathrm{H}, \quad \mathrm{CH}_{2} \mathrm{CH}_{2} \mathrm{NHCON}\right), 3.25(\mathrm{t}, J=7.9 \mathrm{~Hz}, 4 \mathrm{H}$, $\left.\mathrm{CH}_{2} \mathrm{CH}_{2} \mathrm{NHCON}\right), 2.90-2.80\left(\mathrm{~m}, 4 \mathrm{H}, \mathrm{CH}_{2} \mathrm{NH}_{3}^{+}\right), 2.78(\mathrm{t}, J=7.3$ $\mathrm{Hz}, 4 \mathrm{H}$, TrizCH${ }_{2}$ ), 1.76 (quin, $J=7.4 \mathrm{~Hz}, 4 \mathrm{H}, \operatorname{TrizCH}_{2} \underline{\mathrm{C}}_{2}$ ), 1.64 (quin, $J=7.7 \mathrm{~Hz}, 4 \mathrm{H}, \mathrm{C}_{2} \mathrm{CH}_{2} \mathrm{NH}_{3}{ }^{+}$); ${ }^{13} \mathrm{C}$ NMR (DMSO- $d_{6}, 100$ $\mathrm{MHz}) \delta(\mathrm{ppm}): 162.1(\mathrm{NHCON}), 160.2\left(\mathrm{OC}_{\mathrm{Ar}}\right), 158.0$ $\left(\mathrm{CF}_{3} \mathrm{COO}^{-}\right), 155.9\left(\mathrm{C}_{\mathrm{Ar}}\right), 153.3\left(\mathrm{C}_{\mathrm{Ar}}\right), 147.7\left(\mathrm{C}_{\mathrm{Ar}}\right), 138.2\left(\mathrm{C}_{\mathrm{Ar}}\right)$, 134.7 $\left(\mathrm{CH}_{\mathrm{Ar}}\right), 129.4\left(\mathrm{CH}_{\mathrm{Ar}}\right), 126.0\left(\mathrm{CH}_{\mathrm{Ar}}\right), 123.1\left(\mathrm{C}_{\mathrm{Ar}}\right), 121.2\left(\mathrm{C}_{\mathrm{Ar}}\right)$, $120.5\left(\mathrm{CH}_{\mathrm{Ar}}\right), 116.5\left(\mathrm{CH}_{\mathrm{Ar}}\right), 112.1\left(\mathrm{CH}_{\mathrm{Ar}}\right), 104.3\left(\mathrm{CH}_{\mathrm{Ar}}\right), 67.6$ $\left(\mathrm{OCH}_{2}\right), 45.3\left(\mathrm{CH}_{2} \mathrm{CH}_{2} \mathrm{NHCON}\right), 42.4\left(\mathrm{OCH}_{2} \mathrm{CH}_{2}\right), 38.6$ $\left(\mathrm{CH}_{2} \mathrm{NH}_{3}{ }^{+}\right)$, $37.6\left(\mathrm{CH}_{2} \underline{\mathrm{C}}{ }_{2} \mathrm{NHCON}\right), 26.5\left(\mathrm{CH}_{2} \mathrm{CH}_{2} \mathrm{NH}_{3}^{+}\right), 25.6$ $\left(\right.$ TrizCH $\left.{ }_{2} \mathrm{CH}_{2}\right), 24.4\left(\right.$ Triz $\left.\mathrm{CH}_{2}\right) ;$ HPLC (gradient A, Agilent): $R_{\mathrm{t}}=$ 6.4 min; HRMS (ES, positive mode) $m / z$ : calcd for $\mathrm{C}_{46} \mathrm{H}_{52} \mathrm{~N}_{14} \mathrm{O}_{4} \mathrm{~S}_{2}$ 928.3737; found $928.3740(0.27 \mathrm{ppm})$; anal. calcd for $\mathrm{C}_{46} \mathrm{H}_{52} \mathrm{~N}_{14} \mathrm{O}_{4} \mathrm{~S}_{2} .2$ TFA: C, 51.90; H, 4.70; N, 16.95; S, 5.54; found: C, 51.38; H, 5.16; N, 16.98; S, 5.83.

Biological Methods. Chemical Compounds. For LiTryR oxidoreductase activity and dimer quantitation assays, stock solutions of synthesized compounds were prepared in anhydrous DMSO at 5 $\mathrm{mM}$. For the leishmanicidal and cytotoxicity assays, stock solutions of synthesized compounds were prepared in anhydrous DMSO at 15 $\mathrm{mM}$. All reagents for the LiTryR activity assay were obtained from Sigma-Aldrich (St. Louis, MO) except for $\mathrm{TS}_{2}$, which was purchased from Bachem (Bubendorf, Switzerland).

LiTryR Purification. Recombinant L. infantum TryR (LiTryR) HIStagged and HIS-FLAG-tagged versions were used for all LiTryR oxidoreductase activity and dimer quantitation assays. These $L i$ TryR versions were purified from Escherichia coli as previously described. ${ }^{25}$ Briefly, $p$ RSETA-HIS-LiTryR construct alone or in combination with the pET24a-FLAG-LiTryR construct was transformed into BL21 (DE3) Rossetta E. coli strain. An overnight E. coli culture grown at 37 ${ }^{\circ} \mathrm{C}$ in Luria-Bertani (LB) medium with the appropriate antibiotics and vigorous shaking was diluted $(1: 100)$ in the same medium and allowed to grow in the same conditions until the $\mathrm{OD}_{600}$ was 0.5 . Then, $L i$ TryR expression was induced by addition of $1 \mathrm{mM}$ isopropyl- $\beta$-D-1thiogalactopyranoside (IPTG) for $16 \mathrm{~h}$ at $26{ }^{\circ} \mathrm{C}$. The cells were centrifuged for $5 \mathrm{~min}$ at $9000 \mathrm{~g}$ and $4{ }^{\circ} \mathrm{C}$ and the wet pellet

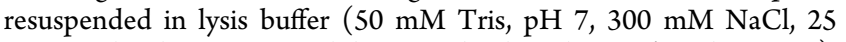
$\mathrm{mM}$ imidazole, protease inhibitor cocktail, and $1 \mathrm{mg} / \mathrm{mL}$ lysozyme). Following a $30 \mathrm{~min}$ incubation on ice, the cell lysate was sonicated on wet ice (50\% pulses, potency 7 ) for $30 \mathrm{~min}$ using a Sonifier Cell Disruptor B15 (Branson, Danbury, CT) and centrifuged for $1 \mathrm{~h}$ at $50000 \mathrm{~g}$ and $4{ }^{\circ} \mathrm{C}$. The supernatant was sonicated again as previously described for $10 \mathrm{~min}$ and loaded on a HisTrap column (GE Healthcare, Chicago, IL) for $16 \mathrm{~h}$ at $4{ }^{\circ} \mathrm{C}$ using a P-1 peristaltic pump (GE Healthcare, Chicago, IL). Once loaded, the HisTrap column was connected to an ÄKTA purifier UPC 10 (GE Healthcare, Chicago, 
IL) and washed using a 5-10\% gradient between buffer A (50 mM Tris, $\mathrm{pH} 7$ and $300 \mathrm{mM} \mathrm{NaCl})$ and $\mathrm{B}(50 \mathrm{mM}$ Tris, $\mathrm{pH}$ 7, $300 \mathrm{mM}$ $\mathrm{NaCl}$, and $500 \mathrm{mM}$ imidazole). LiTryR was eluted using a $40 \%$ gradient between buffers A and B. Fractions containing recombinant LiTryR were pooled and loaded into a HiPrep 26/10 Desalting column (GE Healthcare, Chicago, IL) previously equilibrated with buffer A. Finally, $L i$ TryR was concentrated to $2 \mathrm{mg} / \mathrm{mL}$ using an Amicon Ultra-15 50K (Merck Millipore, Burlington, MA) and an equal volume of glycerol was added before storing at $-20{ }^{\circ} \mathrm{C}$.

TbTryR and TcoTryR Purification. The DNA coding sequences for Homo sapiens GR, T. brucei TryR, and T. congolense TryR were polymerase chain reaction (PCR)-amplified and cloned in the pRSETA plasmid. The DNA coding for hGR (transcript variant 1; NCBI Reference Sequence: NM_000637.5) was purchased from GeneScript. Genomic DNA from $\bar{T}$. congolense parasites was kindly provided by Dr. Stefan Magez (University of Vrije, Brussels). Genomic DNA from the T. brucei S16 cell line was kindly provided by José M. Pérez-Victoria. Instituto de Parasitologia y Biomedicina "López-Neyra" CSIC. HIS-tagged recombinant T. brucei and T. congolense TryRs ( $T b$ TryR and TcoTryR, respectively) were purified from $E$. coli as already explained for LiTryR.

TryR Oxidoreductase Activity. TryR oxidoreductase activity was determined spectrophotometrically using a modified version of the DTNB-coupled assay described by Hamilton et al. ${ }^{52}$ Briefly, reactions were carried out at $26{ }^{\circ} \mathrm{C}$ in $250 \mu \mathrm{L}$ of $\mathrm{N}$-(2-hydroxyethyl)piperazine$N^{\prime}$-ethanesulfonic acid (HEPES) buffer $(\mathrm{pH} 7.5,40 \mathrm{mM})$ containing ethylenediaminetetraacetic acid (EDTA) $(1 \mathrm{mM}), \mathrm{NADP}^{+}(30 \mu \mathrm{M})$, DTNB $(25 \mu \mathrm{M}), \mathrm{TS}_{2}(1 \mu \mathrm{M}), \mathrm{NADPH}(150 \mu \mathrm{M})$, glycerol $(0.02 \%)$, DMSO (1.75\%), and recombinant TryR (7 nM). DTNB, glycerol, and DMSO concentrations used in this assay do not have any relevant effect on the kinetics of the enzymatic reaction. Reactions were started by addition of a mixture of NADPH and $\mathrm{TS}_{2}$.

TryR oxidoreductase activity was monitored at $26{ }^{\circ} \mathrm{C}$ by an increase in absorbance at $412 \mathrm{~nm}$ in an EnSpire Multimode Plate Reader (PerkinElmer, Waltham, MA). 2-Nitro-5-meta mercaptobenzoic acid (TNB) concentration was obtained by multiplying the absorbance values by $100(50 \mu \mathrm{M}$ TNB generates 0.5 arbitrary units of absorbance at $412 \mathrm{~nm}$ ). In this DTNB-coupled assay, one molecule of $\mathrm{T}(\mathrm{SH})_{2}$ reduces one molecule of DTNB, producing two TNB molecules. All of the assays were conducted in at least three independent experiments. Data were analyzed using a nonlinear regression model with GraFit 6 software (Erithacus, Horley, Surrey, U.K.).

hGR Oxidoreductase Activity. hGR oxidoreductase activity was determined spectrophotometrically using a DTNB-coupled assay. Briefly, reactions were carried out at $37^{\circ} \mathrm{C}$ in $250 \mu \mathrm{L}$ of HEPES buffer $(\mathrm{pH} 7.5,40 \mathrm{mM})$ containing EDTA $(1 \mathrm{mM}), \mathrm{NADP}^{+},(60 \mu \mathrm{M})$, DTNB $(150 \mu \mathrm{M})$, oxidized glutathione $(50 \mu \mathrm{M})$, NADPH $(300 \mu \mathrm{M})$, glycerol $(0.02 \%)$, DMSO (1.75\%), and recombinant hGR (7 $\mathrm{nM})$. DTNB, glycerol, and DMSO concentrations used in this assay do not have any relevant effect on the kinetics of the enzymatic reaction. hGR oxidoreductase activity was monitored at $37^{\circ} \mathrm{C}$ by an increase in absorbance at $412 \mathrm{~nm}$ using an EnSpire Multimode Plate Reader (PerkinElmer, Waltham, MA). TNB concentration was obtained by multiplying the absorbance values by $100(50 \mu \mathrm{M}$ TNB generates 0.5 arbitrary units of absorbance at $412 \mathrm{~nm}$ ). All of the assays were conducted in at least three independent experiments. Data were analyzed using a nonlinear regression model with GraFit 6 software (Erithacus, Horley, Surrey, U.K.).

Dimer Quantitation Assay. The stability of the LiTryR dimeric form in the presence of 1,2,3-triazole-phenyl-thiazole-based compounds was evaluated using the novel enzyme-linked immunosorbent assay (ELISA) developed in our laboratory. ${ }^{25}$ Briefly, HIS-FLAGtagged $L i$ TryR $(400 \mathrm{nM})$ was incubated in dimerization buffer $(1 \mathrm{~mL}$ of $300 \mathrm{mM} \mathrm{NaCl}, 50 \mathrm{mM}$ Tris, $\mathrm{pH} 8.0)$ for $16 \mathrm{~h}$ at $37^{\circ} \mathrm{C}$ with agitation and in a humid atmosphere in the presence of the different compounds ranging from 75 to $3.12 \mu \mathrm{M}$. Next, the different solutions were centrifuged at $18000 \mathrm{~g}$ for $15 \mathrm{~min}$ at room temperature. The supernatants $(200 \mu \mathrm{L} /$ well $)$ were added to the $\alpha$-FLAG-coated plates (Sigma-Aldrich, St. Louis, MO) and incubated for $30 \mathrm{~min}$ at $37{ }^{\circ} \mathrm{C}$ with agitation in a humid atmosphere. The plates were washed five times with TTBS buffer $(2 \mathrm{mM}$ Tris, $\mathrm{pH} 7.6,138 \mathrm{mM} \mathrm{NaCl}$, and $0.1 \%$ Tween-20) and incubated with diluted monoclonal $\alpha$-HIS horseradish peroxidase (HRP)-conjugated antibody $(200 \mu \mathrm{L}$, 1:50 000, Abcam, Cambridge, U.K.) in fatty acid- and essentially globulin-free bovine serum albumin (BSA) (5\%) prepared in TTBS buffer for $1 \mathrm{~h}$ at room temperature. The plates were washed five times, and $o$-phenylenediamine dihydrochloride (OPD) substrate prepared according to the manufacturer's instructions was added. The enzymatic reaction was stopped after 5 min with $\mathrm{H}_{2} \mathrm{SO}_{4}(100 \mu \mathrm{L}$, $0.5 \mu \mathrm{M})$, and the absorbances were measured at $490 \mathrm{~nm}$ in an EnSpire Multimode Plate Reader (PerkinElmer, Waltham, MA). All of the assays were conducted in triplicate in at least three independent experiments. Data were analyzed using a nonlinear regression model with GraFit 6 software (Erithacus, Horley, Surrey, U.K.).

Determination of $19 a$ Inhibitory Constants. The inhibitory constants $K_{\mathrm{i}}$ and $K_{\mathrm{i}}^{*}$ for 19a were calculated following a slightly modified version of the standard DTNB-coupled assay. ${ }^{32} \mathrm{TS}_{2}$ was serially diluted (sixfold dilution from 1666 to $52 \mu \mathrm{M}$ ) in a buffer containing $40 \mathrm{mM}$ HEPES ( $\mathrm{pH} 7.5$ ) and $1 \mathrm{mM}$ EDTA. The different $\mathrm{TS}_{2}$ solutions were dispensed $(15 \mu \mathrm{L})$ in a 96-well microplate. 19a was serially diluted in DMSO (sixfold dilution from 1875 to $445 \mu \mathrm{M}$ ). The different aliquots of 19a and the equivalent amount of the vehicle (DMSO) were added to a preassay mixture, yielding different mixtures containing $40 \mathrm{mM}$ HEPES (pH 7.5), 1 mM EDTA, 416.67 $\mu \mathrm{M}$ NADPH, $208.33 \mu \mathrm{M}$ DTNB, $1.45 \%$ DMSO, and different 19a concentrations ranging from 6.2 to $26 \mu \mathrm{M}$. These mixtures $(180 \mu \mathrm{L})$ were subsequently added to the appropriate wells previously filled with different $\mathrm{TS}_{2}$ solutions. The assay was initiated by addition of 55 $\mu \mathrm{L}$ of buffer containing $40 \mathrm{mM}$ HEPES ( $\mathrm{pH} 7.5$ ), 1 mM EDTA, $272.73 \mu \mathrm{M} \mathrm{NADP}^{+}$, $0.01 \%$ glycerol, and $3.5 \mathrm{nM}$ recombinant $L i$ TryR using an automated dispensing system (PerkinElmer, Waltham, MA). The order of addition was essential to avoid enzyme preincubation with the inhibitor or the substrates. The final $250 \mu \mathrm{L}$ assay contained $40 \mathrm{mM}$ HEPES buffer (pH 7.5) $1 \mathrm{mM}$ EDTA, $300 \mu \mathrm{M}$ NADPH, 60 $\mu \mathrm{M} \mathrm{NADP}{ }^{+}, 150 \mu \mathrm{M}$ DTNB, 6.25-50 $\mu \mathrm{M} \mathrm{TS}_{2}, 1.04 \%$ DMSO, $0.002 \%$ glycerol, and $0.8 \mathrm{nM}$ recombinant $L i$ TryR. TryR oxidoreductase activity was monitored at $26^{\circ} \mathrm{C}$ by an increase in absorbance at $412 \mathrm{~nm}$ in an EnSpire Multimode Plate Reader (PerkinElmer, Waltham, MA). Coupling an automated dispenser module to the spectrophotometer enabled real-time detection of the enzymatic reaction, which was crucial for high-quality nonlinear fits of the experimental data and, especially, to estimate the initial velocity of the progress curves in the presence of 19a. To guarantee linearity of the enzyme reaction in the absence of an inhibitor, the analysis was performed with data obtained during the first $20000 \mathrm{~s}$ to avoid $\mathrm{TS}_{2}$ depletion. Under this condition, all uninhibited reactions followed straight lines until the generation of $230 \mu \mathrm{M}$ TNB (Figure S10). This product concentration was never reached in the inhibited reactions during the first $20000 \mathrm{~s}$. All of the assays were conducted in three independent experiments.

Data and Statistical Analysis. GraFit 6.0 software (Erithacus, Horley, SRY, U.K.) was used to perform linear and nonlinear regressions. All experiments were undertaken in triplicate to ensure the reliability of single values.

$k_{\text {obs }}$ values were estimated for every 19a concentration at all $\mathrm{TS}_{2}$ concentrations by fitting the values of the TNB concentration produced during each enzymatic reaction to eq $1 .{ }^{42 b, 53}$

$$
[\mathrm{P}]=v_{\mathrm{s}} t+\frac{v_{\mathrm{i}}-v_{\mathrm{s}}}{k_{\mathrm{obs}}}\left[1-\exp \left(-k_{\mathrm{obs}} t\right)\right]+d
$$

where $v_{\mathrm{i}}$ and $v_{\mathrm{s}}$ are the initial and the steady-state velocities, respectively, $k_{\mathrm{obs}}$ is the apparent first-order rate constant for the conversion of $v_{\mathrm{i}}$ into the steady-state velocity $\left(v_{\mathrm{s}}\right)$, and $d$ is a parameter that indicates the displacement of the curve on the vertical ordinate and takes into account any nonzero value of the measured signal at time zero caused by some of the reagents. The apparent inhibition constants $\left(K_{\mathrm{i}}^{\text {app }}\right.$ and $\left.K_{\mathrm{i}}^{* \text { app }}\right)$ for each $\mathrm{TS}_{2}$ concentration were determined by fitting the $k_{\text {obs }}$ values obtained at different $19 \mathrm{a}$ concentrations to eq 2 


$$
k_{\mathrm{obs}}=k_{6}\left[\begin{array}{l}
1+\frac{[\mathrm{I}]}{K_{\mathrm{i}}^{* \text { app }}} \\
1+\frac{[\mathrm{I}]}{K_{\mathrm{i}}^{\text {app }}}
\end{array}\right]
$$

where $K_{\mathrm{i}}^{\text {app }}$ is the apparent value of the $K_{\mathrm{i}}$ for the initial encounter complex (EI) and $K_{\mathrm{i}}^{* \text { *app }}$ is the apparent value of the overall inhibition constant $K_{\mathrm{i}}^{*}$ to form a higher-affinity complex $\left(\mathrm{E}^{*} \mathrm{I}\right) . k_{6}$ is the firstorder rate constant that defines the reverse isomerization step that returns $\mathrm{E}^{*} \mathrm{I}$ to $\mathrm{EI}^{42 \mathrm{a}, 53}$

The $K_{\mathrm{i}}$ value for the formation of the EI complex was determined by fitting the $K_{\mathrm{i}}^{\text {app }}$ values obtained at different $\mathrm{TS}_{2}$ concentrations to eq 3. In addition, this graph was used to assess the inhibition modality of 19a during the first equilibrium of its two-step binding mechanism. The value obtained for $\alpha$ defines the mode of inhibition (competitive, $\alpha \rightarrow$ infinite; uncompetitive, $\alpha \rightarrow 0$; pure noncompetitive, $\alpha=1$; mixed, $1<\alpha<10)^{42 a}$

$$
K_{\mathrm{i}}^{\text {app }}=\frac{[\mathrm{S}]+K_{\mathrm{m}}}{\frac{K_{\mathrm{m}}}{K_{\mathrm{i}}}+\frac{[\mathrm{S}]}{\alpha K_{\mathrm{i}}}}
$$

The overall inhibition constant $K_{\mathrm{i}}^{*}$ value was determined by fitting the $K_{1}^{* a p p}$ values obtained at different $\mathrm{TS}_{2}$ concentrations to eq 4 . In addition, this graph was used to assess the overall inhibition modality of 19a during its two-step binding mechanism. As explained above, the value obtained for $\alpha$ defines the mode of inhibition. ${ }^{42 a}$

$$
K_{\mathrm{i}}^{* \text { app }}=\frac{[\mathrm{S}]+K_{\mathrm{m}}}{\frac{K_{\mathrm{m}}}{K_{\mathrm{i}}}+\frac{[\mathrm{S}]}{\alpha K_{\mathrm{i}}{ }^{*}}}
$$

Leishmania Cell Lines and Culture. L. infantum promastigotes (MCAN/ES/89/IPZ229/1/89) were grown in Roswell Park Memorial Institute (RPMI)-1640 medium (Sigma-Aldrich, St. Louis, MO) supplemented with $10 \%$ heat-inactivated fetal calf serum (FCS), antibiotics, and $25 \mathrm{mM}$ HEPES ( $\mathrm{pH} 7.2$ ) at $26{ }^{\circ} \mathrm{C}$. L. infantum axenic amastigotes (MCAN/ES/89/IPZ229/1/89) were grown in M199 medium (Invitrogen, Leiden, The Netherlands) supplemented with $10 \%$ heat-inactivated FCS, $1 \mathrm{~g} / \mathrm{L} \beta$-alanine, 100 $\mathrm{mg} / \mathrm{L}$ L-asparagine, $200 \mathrm{mg} / \mathrm{L}$ sucrose, $50 \mathrm{mg} / \mathrm{L}$ sodium pyruvate, 320 $\mathrm{mg} / \mathrm{L}$ malic acid, $40 \mathrm{mg} / \mathrm{L}$ fumaric acid, $70 \mathrm{mg} / \mathrm{L}$ succinic acid, 200 $\mathrm{mg} / \mathrm{L} \alpha$-ketoglutaric acid, $300 \mathrm{mg} / \mathrm{L}$ citric acid, $1.1 \mathrm{~g} / \mathrm{L}$ sodium bicarbonate, $5 \mathrm{~g} / \mathrm{L}$ morpholineethanesulfonic acid (MES), $0.4 \mathrm{mg} / \mathrm{L}$ hemin, and $10 \mathrm{mg} / \mathrm{L}$ gentamicine, $\mathrm{pH} 5.4$, at $37^{\circ} \mathrm{C}$.

Axenization of $L$. infantum Promastigotes. Axenization was performed by diluting $0.5 \mathrm{~mL}$ of a 7-day stationary phase culture of $L$. infantum promastigotes $\left(2-3 \times 10^{7}\right.$ parasites $\left./ \mathrm{mL}\right)$ in $4.5 \mathrm{~mL}$ of amastigotes medium and incubating the culture at $37^{\circ} \mathrm{C}$ for 2 or 3 days. L. infantum axenic amastigotes apparition was followed by phase-contrast microscopy using an Eclipse Ti inverted microscope (Nikon, Tokyo, Japan).

Leishmanicidal Activity. Drug treatment of L. infantum promastigotes was performed during the logarithmic growth phase at a concentration of $2 \times 10^{6}$ parasites $/ \mathrm{mL}$ at $26{ }^{\circ} \mathrm{C}$ for $24 \mathrm{~h}$. Drug treatment of $L$. infantum axenic amastigotes was performed during the logarithmic growth phase at a concentration of $1 \times 10^{6}$ parasites $/ \mathrm{mL}$ at $37{ }^{\circ} \mathrm{C}$ for $24 \mathrm{~h} . \mathrm{EC}_{50}$ was evaluated by flow cytometry by the propidium iodide (PI) exclusion method. After selection of the parasite population based on their forward scatter (FSC) and side scatter (SSC) values, live and dead parasite cells were identified by their permeability to PI. All of the assays were conducted in triplicate in at least three independent experiments. Data were analyzed using a nonlinear regression model with GraFit 6 software (Erithacus, Horley, Surrey, U.K.).

Fluorescence Microscopy. Logarithmic growth phase promastigotes were treated with $25 \mu \mathrm{M} \mathrm{12a}$ for $1 \mathrm{~h}$ at $26^{\circ} \mathrm{C}$. Parasites were fixed using a solution containing EDTA $(450 \mathrm{mM})$ and mounted on polylysine slides (Thermo Scientific, Waltham, MA). Images were captured with an Eclipse Ti inverted microscope (Nikon, Tokyo, Japan).
Human Cell Line Culture. THP-1 cells were grown in RPMI-1640 medium (Gibco, Leiden, The Netherlands) supplemented with $10 \%$ heat-inactivated FCS, antibiotics, $10 \mathrm{mM}$ HEPES, $2 \mathrm{mM}$ glutamine, and $1 \mathrm{mM}$ sodium pyruvate, $\mathrm{pH} 7.2$, at $37{ }^{\circ} \mathrm{C}$ and $5 \% \mathrm{CO}_{2}$.

Liver hepatocellular carcinoma HepG2 cells were grown in Dulbecco's modified Eagle's medium (DMEM) (Sigma-Aldrich, St. Louis, MO) with $10 \%$ heat-inactivated FCS, antibiotics, and $10 \mathrm{mM}$ HEPES.

Determination of Cellular Toxicity. Drug treatment of liver hepatocellular carcinoma HepG2 cells was performed at a concentration of $10^{5}$ cells $/ \mathrm{mL}$ at $37{ }^{\circ} \mathrm{C}$ and $5 \% \mathrm{CO}_{2}$ for $24 \mathrm{~h} . \mathrm{EC}_{50}$ was evaluated by the crystal violet assay. Briefly, cells were washed with phosphate-buffered saline (PBS) and stained with $200 \mu \mathrm{L}$ of crystal violet solution $(0.2 \%$ crystal violet, $2 \%$ ethanol $)$ for $10 \mathrm{~min}$ at room temperature. Next, the plates were washed twice with tap water and allowed to dry. The stained cells were solubilized with $400 \mu \mathrm{L}$ of $1 \%$ sodium dodecyl sulfate (SDS), and the color intensity was quantified at $570 \mathrm{~nm}$ using an EnSpire Multimode Plate Reader (PerkinElmer, Waltham, MA). All of the assays were conducted in triplicate in at least three independent experiments. Data were analyzed using a nonlinear regression model with GraFit 6 software (Erithacus, Horley, Surrey, U.K.).

In Vitro Infection of THP-1-Derived Macrophages with GFPExpressing L. infantum Axenic Amastigotes. THP-1 monocytes were seeded in a 48 -well plate at a concentration of $5 \times 10^{5}$ cells $/ \mathrm{mL}$ $(250 \mu \mathrm{L} /$ well $)$ in RPMI complete medium supplemented with phorbol 12-myristate 13-acetate (PMA) $(100 \mathrm{ng} / \mathrm{mL})$. Differentiation of THP-1 monocytes to macrophages was allowed for $24 \mathrm{~h}$ at $37^{\circ} \mathrm{C}$ and $5 \% \mathrm{CO}_{2}$. THP-1-derived macrophages were infected with GFPexpressing axenic amastigotes at $5 \times 10^{6}$ parasites $/ \mathrm{mL}$ in $\mathrm{RPMI}$ complete medium for $24 \mathrm{~h}(250 \mu \mathrm{L} /$ well $)$. Extracellular amastigotes were washed twice with PBS. The remaining extracellular parasites were challenged for $24 \mathrm{~h}$ with THP-1 medium supplemented with $10 \%$ horse serum (Gibco) instead of FCS. Cells were washed twice with PBS, and treatments were performed in $250 \mu \mathrm{L}$ of fresh RPMI medium supplemented with $10 \%$ horse serum for $72 \mathrm{~h}$ at $37{ }^{\circ} \mathrm{C}$ and $5 \% \mathrm{CO}_{2}$. Afterward, treatments were removed by two PBS washes. Lysis of infected cells was performed with $120 \mu \mathrm{L}$ of SDS $0.005 \%$ (w/ v) in PBS. After a 30 min incubation at $37{ }^{\circ} \mathrm{C}$, lysis was stopped by adding RPMI complete medium with PI at $20 \mu \mathrm{g} / \mathrm{mL}(120 \mu \mathrm{L} /$ well $)$. The lysates were transferred to a 96 -well plate $(200 \mu \mathrm{L} /$ well $)$, and the $\mathrm{GFP}^{+}$amastigotes extracted from the infected cells were acquired by a Beckman Coulter FC500 flow cytometer. Each sample (100 $\mu \mathrm{L})$ was acquired for $20 \mathrm{~s}$.

Cytotoxicity of THP-1 infected macrophages was determined using an in-house developed lactate dehydrogenase (LDH) activity assay. $\mathrm{LDH}$ activity assays from the remaining cell lysates $(100 \mu \mathrm{L} /$ well $)$ were carried out at $37^{\circ} \mathrm{C}$ in $250 \mu \mathrm{L}$ of Tris/ $\mathrm{HCl}$ buffer $(\mathrm{pH} 8.9,50$ $\mathrm{mM})$ containing DL-lactate $(840 \mathrm{mM}), \mathrm{NAD}^{+}(450 \mu \mathrm{M})$, 1methoxyphenazine methosulfate $(45 \mu \mathrm{M})$, and nitro blue tetrazolium chloride $(40 \mu \mathrm{M})$. The color intensity of the generated formazan dye was monitored at $570 \mathrm{~nm}$ using an EnSpire Multimode Plate Reader (PerkinElmer, Waltham, MA). $\mathrm{CC}_{50}$ values were calculated using a nonlinear regression model with GraFit 6 software (Erithacus, Horley, Surrey, U.K.).

The relative number of $\mathrm{GFP}^{+}$intracellular amastigotes per cell in each sample was estimated after the division of the total number of GFP+ amastigotes by the LDH activity value of the sample. Results were normalized to the vehicle-treated controls. $\mathrm{EC}_{50}$ values of intracellular amastigotes were calculated using a nonlinear regression model with GraFit 6 software (Erithacus, Horley, Surrey, U.K.). All of the assays were conducted in at least three independent experiments.

Screening for Pan-Assay Interference Compounds (PAINS) and Aggregation. Screening of all tested compounds for pan-assay interference compounds (PAINS) and aggregation via public tools (http://zinc15.docking.org/patterns/home/ and https://www.cbligand.org/PAINS/) gave no hits. Dose-response curves for all experiments and compounds were recorded. None of the curves showed Hill slopes that could be a hint for PAINS (curves for representative compounds $\mathbf{1 2 b}$ and $\mathbf{1 2 c}$ are presented in Figure S14, 
Supporting information). Counter-screening against related (glutathione reductase; GR) and unrelated (superoxide dismutase) targets discarded any nonspecific activity of the compounds. Reaction curves for TryR and GR in the presence of compounds $12 \mathrm{~b}$ and $12 \mathrm{c}$ are shown in Figure S15. Nifurtimox is included as a well-characterized inhibitor of GR. SAR, considered the most relevant criterion that distinguishes a PAIN from a non-PAIN, is deeply discussed in the manuscript. $^{54}$

Computational Methods. Automated Ligand Docking. A three-dimensional cubic grid consisting of $65 \times 65 \times 65$ points with a spacing of $0.375 \AA$ centered midway between the two active sites of LiTryR was defined for ligand docking. Electrostatic, desolvation, and affinity maps for the atom types present in the ligands of this series were calculated using AutoGrid 4.2.6. Then, the Lamarckian genetic algorithm implemented in AutoDock $4{ }^{49}$ was used to generate up to 100 feasible binding poses of the ligands studied. The best poses were selected on the basis of results from intra- and intermolecular energy evaluations.

Molecular Dynamics Simulations. The leaprcff14SB AMBER force field and the graphics processing unit (GPU)-based implementation of the pmemd.cuda module of Amber16 in the single-precision-fixed-precision (SPFP) mode were used, as described before. ${ }^{30}$ The molecular dynamics trajectories were analyzed using the cpptraj module of AmberTools18, and the binding energy analysis was carried out with our in-house tool MM-ISMSA. ${ }^{53}$ The molecular graphics program $\mathrm{PyMOL}^{56}$ was employed for molecular editing, visualization, and figure preparation.

\section{ASSOCIATED CONTENT}

\section{(S) Supporting Information}

The Supporting Information is available free of charge at https://pubs.acs.org/doi/10.1021/acs.jmedchem.1c00206.

Additional synthesis; biological and computational assays; screening of representative compounds for PAINS; ${ }^{1} \mathrm{H}$ NMR, ${ }^{13} \mathrm{C}$ NMR, and HRMS spectra and HPLC chromatograms for all of the target compounds (PDF)

Molecular formula strings of the prepared compounds and biological data (CSV)

Movie of LiTryR-19a complex (Movie S1) (AVI)

\section{AUTHOR INFORMATION}

\section{Corresponding Authors}

Antonio Jiménez-Ruiz - Departamento de Biología de Sistemas, Universidad de Alcalá, E-28805 Alcalá de Henares, Madrid, Spain; Phone: (+34) 918855109;

Email: antonio.jimenez@uah.es

Sonsoles Velázquez - Instituto de Química Médica (IQMCSIC), E-28006 Madrid, Spain; @ orcid.org/0000-00032209-1751; Phone: (+34) 912587689; Email: iqmsv29@ iqm.csic.es

\section{Authors}

Alejandro Revuelto - Instituto de Química Médica (IQMCSIC), E-28006 Madrid, Spain

Héctor de Lucio - Departamento de Biología de Sistemas, Universidad de Alcalá, E-28805 Alcalá de Henares, Madrid, Spain; 이이이.org/0000-0002-9840-0779

Juan Carlos García-Soriano - Departamento de Biología de Sistemas, Universidad de Alcalá, E-28805 Alcalá de Henares, Madrid, Spain

Pedro A. Sánchez-Murcia - Área de Farmacología, Departamento de Ciencias Biomédicas, Unidad Asociada al IQM-CSIC, Universidad de Alcalá, E-28805 Alcalá de
Henares, Madrid, Spain; 이이.org/0000-0001-8415$870 \mathrm{X}$

Federico Gago - Área de Farmacología, Departamento de Ciencias Biomédicas, Unidad Asociada al IQM-CSIC, Universidad de Alcalá, E-28805 Alcalá de Henares, Madrid, Spain; 이이.org/0000-0002-3071-4878

María-José Camarasa - Instituto de Química Médica (IQM-

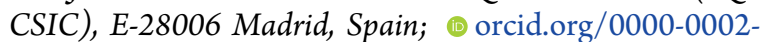
4978-6468

Complete contact information is available at:

https://pubs.acs.org/10.1021/acs.jmedchem.1c00206

\section{Author Contributions}

${ }^{A}$ A.R. and H.d.L. contributed equally to this work.

\section{Author Contributions}

F.G., M.-J.C., A.J.-R., and S.V.: participated in research design. A.R.: carried out the synthesis. H.d.L. and J.C.G.-S.: performed biological evaluations. A.R., P.A.S.-M., and F.G.: conducted computational studies. F.G., A.J.-R., and S.V.: performed data analysis and supervised experiments. A.R., H.d.L., F.G., A.J.-R., M.-J.C., and S.V.: wrote or contributed to the writing of the manuscript. All authors have given approval to the final version of the manuscript.

Notes

The authors declare no competing financial interest.

\section{ACKNOWLEDGMENTS}

This work has been supported by the Spanish MICINN (Projects PID2019-104070RB-C21 and PID2019-104070RBC22), the Spanish Agencia Estatal Consejo Superior de Investigaciones Científicas (CSIC, Projects CSIC-PIE201980E100 and CSIC-PIE-201980E028), and the Comunidad de Madrid (PLATESA2-CM ref S-2018/BAA-4370). The Spanish MEC is also acknowledged for FPU grants to A.R. and J.C.G.-S.

\section{ABBREVIATIONS}

CCTLC, centrifugal circular thin-layer chromatography; CuAAC, 1,3-dipolar copper(I)-catalyzed azide-alkyne cycloaddition; $\mathrm{EC}_{50 \mathrm{a}}$, half-maximal effective concentration in amastigotes; $\mathrm{EC}_{50 \mathrm{p}}$, half-maximal effective concentration in promastigotes; HepG2, liver hepatocellular carcinoma; $\mathrm{IC}_{50}{ }^{\text {act }}$, half-maximum inhibitory concentration in the activity assay; $\mathrm{IC}_{50}{ }^{\mathrm{dim}}$, half-maximum inhibitory concentration in the dimerization assay; GR, glutathione reductase; LiTryR, Leishmania infantum trypanothione reductase; $\mathrm{LDH}$, lactate dehydrogenase; PI, propidium iodide; RuAAC, rutheniumcatalyzed azide-alkyne cycloaddition; $\mathrm{SI}_{a}$, selectivity index in amastigotes; $\mathrm{SI}_{\mathrm{p}}$, selectivity index in promastigotes; $\mathrm{Tb}$ TryR, Trypanosoma brucei trypanothione reductase; TcoTryR, Trypanosoma congolense trypanothione reductase; Try/TryR, thypanothione/trypanothione reductase; $\mathrm{TS}_{2}$, trypanothione disulfide; VL, visceral leishmaniasis

\section{REFERENCES}

(1) WHO. Leishmaniasis; WHO, 2020. Available online: http:/www. who.int/gho/neglected_diseases/leishmaniasis/en/ (accessed Oct, 2020).

(2) Ready, P. D. Epidemiology of visceral leishmaniasis. Clin. Epidemiol. 2014, 6, 147-154.

(3) Gillespie, P. M.; Beaumier, C. M.; Strych, U.; Hayward, T.; Hotez, P. J.; Bottazzi, M. E. Status of vaccine research and 
development of vaccines for leishmanisis. Vaccine 2016, 34, 29922995.

(4) Chakravarty, J.; Sundar, S. Current and emerging medications for the treatment of leishmaniasis. Exp. Opin. Pharmacother. 2019, 20, $1251-1265$

(5) Alves, F.; Bilbe, G.; Blesson, S.; Goyal, V.; Monnerat, S.; Mowbray, C.; Ouattara, G. M.; Pécoul, B.; Rijal, S.; Rode, J.; Solomos, A.; Strub-Wourgaft, N.; Wasunna, M.; Wells, S.; Zijlstra, E. E.; Arana, B.; Alvar, J. Recent developments of visceral leishmaniasis treatments: successes, pitfalls and perspectives. Clin. Microbiol. Rev. 2018, 31, No. e00048-18.

(6) Ponte-Sucre, A.; Gamarro, F.; Dujardin, J. C.; Barrett, M. P.; López-Vélez, R.; García-Hernández, R.; Pountain, A. W.; Mwenechanya, R.; Papadopoulou, B. Drug resistance and treatment failure in leishmaniasis: a 21 st century challenge. PLoS Negl. Trop. Dis. 2017, 11, No. e0006052.

(7) Jain, V.; Jain, K. Molecular targets and pathways for the treatment of visceral leishmaniasis. Drug Discovery Today 2018, 23, $161-170$.

(8) Mansuri, R.; Singh, J.; Diwan, A. An insight into the current perspective and potential drug targets for visceral leishmaniasis (VL). Curr. Drug Targets 2020, 21, 1105-1129.

(9) Krauth-Siegel, R. L.; Meiering, S. K.; Schmidt, H. The parasitespecific trypanothione metabolism of trypanosoma and leishmania. Biol. Chem. 2003, 384, 539-549.

(10) Frearson, J. A.; Wyatt, P. A.; Gilbert, I. H.; Fairlamb, A. H. Target assessment for antiparasitic drug discovery. Trends Parasitol. 2007, 23, 589-595.

(11) Leroux, A. E.; Krauth-Siegel, R. L. Thiol redox biology of trypanosomatids and potential targets for chemotherapy. Mol. Biochem. Parasitol. 2016, 206, 67-74.

(12) Field, M. C.; Horn, D.; Fairlamb, A. H.; Ferguson, M. A. J.; Gray, D. W.; Read, K. D.; De Rycker, M.; Torrie, L. S.; Wyatt, P. G.; Wyllie, S.; Gilbert, I. H. Anti-trypanosomatid drug discovery: an ongoing challenge and a continuing need. Nat. Rev. Microbiol. 2017, $15,217-231$.

(13) Tiwari, N.; Tanwar, N.; Munde, M. Molecular insights into trypanothione reductase-inhibitor interaction: A structure-based review. Arch. Pharm. 2018, 351, No. 1700373.

(14) Battista, T.; Gianni, C.; Ilari, A.; Fiorillo, A. Targeting trypanothione reductase, a key enzyme in the redox trypanosomatid metabolism, to develop new drugs against leishmaniasis and trypanosomiases. Molecules 2020, 25, No. 1924.

(15) Saccoliti, F.; Di Santo, R.; Costi, R. Recent advancement in the search of innovative antiprotozoal agents targeting trypanothione metabolism. ChemMedChem 2020, 15, 2420-2435.

(16) Patterson, S.; Alphey, M. S.; Jones, D. C.; Shanks, E. J.; Street, I. P.; Frearson, J. A.; Wyatt, P. G.; Gilbert, I. H.; Fairlamb, A. H. Dihydroquinazolines as a novel class of Trypanosoma brucei trypanothione reductase inhibitors: discovery, synthesis and characterization of their binding mode by protein crystallography. J. Med. Chem. 2011, 54, 6514-6530.

(17) Ilari, A.; Fiorillo, A.; Genovese, I.; Colotti, G. Polyaminetrypanothione pathway: an update. Future Med. Chem. 2017, 9, 6177.

(18) Dumas, C.; Oullette, M.; Tovar, J.; Cunningham, M. L.; Fairlamb, A. H.; Tamar, S.; Olivier, M.; Papadopoulou, B. Disruption of the trypanothione reductase gene of Leishmania decreases its ability to survive oxidative stress in macrophages. EMBO J. 1997, 16, 25902598.

(19) De Gasparo, R.; Halgas, O.; Harangozo, D.; Kaiser, M.; Pai, E. F.; Krauth-Siegel, R. L.; Diederich, F. Targeting a large active site: structure-based design of nanomolar inhibitors of Trypanosoma brucei trypanothione reductase. Chem. - Eur. J. 2019, 25, 11416-11421.

(20) (a) Fairlamb, A. H.; Ridley, R. G.; Vial, H. J. Drugs against Parasitic Diseases: R\&D Methodologies and Issues, Discoveries and Drug Development, TDR/PRD/03.1; WHO: Geneva, 2003; pp 107-118. (b) Wyllie, S.; Cunningham, M. L.; Fairlamb, A. H. Dual action of antimonial drugs on thiol redox metabolism in the human pathogen Leishmania donovani. J. Biol. Chem. 2004, 279, 39925-39932.

(21) Krieger, S.; Schwarz, W.; Ariyanayagam, M. R.; Fairlamb, A. H.; Krauth-Siegel, R. L.; Clayton, C. Trypanosomes lacking trypanothione reductase are avirulent and show increased sensitivity to oxidative stress. Mol. Microbiol. 2000, 35, 542-552.

(22) (a) Baiocco, P.; Franceschini, S.; Ilari, A.; Colotti, G. Trypanothione reductase from Leishmania infantum: cloning, expression, purification, crystallization and preliminary X-ray data analysis. Protein Pept. Lett. 2009, 16, 196-200. (b) Baiocco, P.; Colotti, G.; Franceschini, S.; Ilari, A. Molecular basis of antimony treatment in leishmaniasis. J. Med. Chem. 2009, 52, 2603-2612.

(23) Persch, E.; Bryson, S.; Todoroff, N. K.; Eberle, C.; Thelemann, J.; Dirdjaja, N.; Kaiser, M.; Weber, M.; Derbani, H.; Brun, R.; Schneider, G.; Pai, E. F.; Krauth-Siegel, R. L.; Diederich, F. Binding to large enzyme pockets: small-molecule inhibitors of trypanothione reductase. ChemMedChem 2014, 9, 1880-1891.

(24) De Gasparo, R.; Brodbeck-Persch, E.; Bryson, S.; Hentzen, N. B.; Kaiser, M.; Pai, E. F.; Krauth-Siegel, R. L.; Diederich, F. Biological evaluation and X-ray Co-crystal structures of cyclohexylpyrrolidine ligands for trypanothione reductase, an enzyme from the redox metabolism of trypanosoma. ChemMedChem 2018, 13, 957-967.

(25) Toro, M. A.; Sánchez-Murcia, P. A.; Moreno, D.; RuizSantaquiteria, M.; Alzate, J. F.; Negri, A.; Camarasa, M. J.; Gago, F.; Velázquez, S.; Jiménez-Ruiz, A. Probing the dimerization interface of Leishmania infantum trypanothione reductase with site-directed mutagenesis and short peptides. ChemBioChem 2013, 14, 1212-1217.

(26) Sánchez-Murcia, P. A.; Ruiz-Santaquiteria, M.; Toro, M. A.; De Lucio, H.; Jiménez, M. A.; Gago, F.; Jiménez-Ruiz, A.; Camarasa, M. J.; Velázquez, S. Comparison of hydrocarbon- and lactam-bridged cyclic peptides as dimerization inhibitors of Leishmania infantum trypanothione reductase. RSC Adv. 2015, 5, 55784-55794.

(27) Ruiz-Santaquiteria, M.; De Castro, S.; Toro, M. A.; De Lucio, H.; Gutiérrez, K. J.; Sánchez-Murcia, P. A.; Jiménez, M. A.; Gago, F.; Jiménez-Ruiz, A.; Camarasa, M. J.; Velázquez, S. Trypanothione reductase inhibition and anti-leishmanial activity of all-hydrocarbon stapled -helical peptides with improved proteolytic stability. Eur. J. Med. Chem. 2018, 149, 238-247.

(28) De Lucio, H.; Gamo, A. M.; Ruiz-Santaquiteria, M.; De Castro, S.; Sánchez-Murcia, P. A.; Toro, M. A.; Gutiérrez, K. J.; Gago, F.; Jiménez-Ruiz, A.; Camarasa, M. J.; Velázquez, S. Improved proteolytic stability and potent activity against Leishmania infantum trypanothione reductase of $\alpha / \beta$-peptide foldamers conjugated to cellpenetrating peptides. Eur. J. Med. Chem. 2017, 140, 615-623.

(29) Ruiz-Santaquiteria, M.; Sánchez-Murcia, P. A.; Toro, M. A.; De Lucio, H.; Gutiérrez, K. J.; De Castro, S.; Carneiro, F. A. C.; Gago, F.; Jiménez-Ruiz, A.; Camarasa, M. J.; Velázquez, S. First example of peptides targeting the dimer interface of Leishmania infantum trypanothione reductase with potent in vitro antileishmanial activity. Eur. J. Med. Chem. 2017, 135, 49-59.

(30) Revuelto, A.; Ruiz-Santaquiteria, M.; De Lucio, H.; Gamo, A.; Carriles, A. A.; Gutiérrez, K. J.; Sánchez-Murcia, P. A.; Hermoso, J. A.; Gago, F.; Camarasa, M. J.; Jiménez-Ruiz, A.; Velázquez, S. Pyrrolopyrimidine vs imidazole-phenyl-thiazole scaffolds in nonpeptidic dimerization inhibitors of Leishmania infantum trypanothione reductase. ACS Infect. Dis. 2019, 5, 873-891.

(31) Davis, J. M.; Tsou, L. K.; Hamilton, A. D. Synthetic nonpeptide mimetics of $\alpha$-helices. Chem. Soc. Rev. 2007, 36, 326-334.

(32) Azzarito, V.; Long, K.; Murphy, N. S.; Wilson, A. J. Inhibition of -helix-mediated protein-protein interactions using designed molecules. Nat. Chem. 2013, 5, 161-173.

(33) Wilson, A. J. Helix mimetics: recent developments. Prog. Biophys. Mol. Biol. 2015, 119, 33-40.

(34) Lee, J. H.; Zhang, Q.; Jo, S.; CHai, S. C.; Oh, M.; Im, W.; Lu, H.; Lim, H.-S. Novel pyrrolopyrimidine-based -helix mimetics: cellpermeable inhibitors of protein-protein interactions. J. Am. Chem. Soc. 2011, 133, 676-679. 
(35) Cummings, C. G.; Ross, N. T.; Katt, W. P.; Hamilton, A. D. Synthesis and biological evaluation of a 5-6-5 imidazole-phenylthiazole based -helix mimetic. Org. Lett. 2009, 11, 25-28.

(36) Kharb, R.; Chander, P.; Yar, M. S. Pharmacological significance of triazole scaffold. J. Enzyme Inhib. Med. Chem. 2011, 26, 1-21.

(37) Lauria, A.; Delisi, R.; Mingoia, F.; Terenzi, A.; Martorana, A.; Barone, G.; Almerico, A. M. 1,2,3-triazole in heterocyclic compounds, endowed with biological activity through 1,3-dipolar cycloadditions. Eur. J. Org. Chem. 2014, 2014, 3289-3306.

(38) (a) Dheer, D.; Singh, V.; Shankar, R. Medicinal attributes of 1,2,3-triazoles: current developments. Bioorg. Chem. 2017, 71, 30-54. (b) Bozorov, K.; Zhao, J.; Aisa, H. A. 1,2,3-triazole-containing hybrids as leads in medicinal chemistry: a recent overview. Bioorg. Med. Chem. 2019, 27, 3511-3531.

(39) See for example (a) Teixeira, R. R.; Rodrigues Gazolla, P. A.; Da Silva, A. M.; Goncalves Borsodi, M. P.; Bergmann, B. R.; Salgado Ferreira, R.; Gontijo Vaz, B.; Vasconcelos, G. A.; Lima, W. P. Synthesis and leishmanicidal activity of eugenol derivatives bearing 1,2,3-triazole functionalities. Eur. J. Med. Chem. 2018, 146, 274-286. (b) Maji, K.; Abbasi, M.; Podder, D.; Datta, R.; Haldar, D. Potential antileishmanial activity of a triazole-based hybrid peptide against Leishmania major. ChemistrySelect 2018, 3, 10220-10225.

(40) See for example reviews (a) Haldón, E.; Nicasio, M. C.; Pérez, P. J. Copper-catalyzed azide-alkyne cycloadditions (CuAAC): an update. Org. Biomol. Chem. 2015, 13, 9528-9550. (b) Johansson, J. R.; Beke-Somfai, T.; Stalsmeden, A. S.; Kann, N. Ruthenium-catalyzed azide alkyne cycloaddition reaction: scope, mechanism and applications. Chem. Rev. 2016, 116, 14726-14768.

(41) Lucio, H.; Toro, M. A.; Camarasa, M. J.; Velázquez, S.; Gago, F.; Jiménez-Ruiz, A. Pseudoirreversible slow-binding inhibition of trypanothione reductase by a protein-protein interaction disruptor. $\mathrm{Br}$. J. Pharmacol. 2020, 177, 5163-5176.

(42) (a) Copeland, R. A. Enzymes: A Practical Introduction to Structure. Mechanism and Data Analysis, 2nd ed.; John Wiley \& Sons, Inc.: New York, 2000. (b) Copeland, R. A. Evaluation of Enzyme Inhibitors in Drug Discovery: A Guide for Medicinal Chemists and Pharmacologists, 2nd ed.; John Wiley \& Sons, Inc.: Hoboken, NJ, 2013.

(43) Kozakov, D.; Grove, L. E.; Hall, D. R.; Bohnuud, T.; Mottarella, S. E.; Luo, L.; Xia, B.; Beglov, D.; Vajda, S. The FTMap family of web servers for determining and characterizing ligand-binding hot spots of proteins. Nat. Protoc. 2015, 10, 733-755.

(44) Sarma, G. N.; Savvides, N.; Becker, K.; Schirmer, M.; Schirmer, R. H.; Karplus, P. A. Glutathione reductase of the malarial parasite Plasmodium falciparum: crystal structure and inhibitor development. J. Mol. Biol. 2003, 328, 893-907.

(45) Karplus, P. A.; Pai, E. F.; Schulz, G. E. A crystallographic study of the glutathione binding site of glutathione reductase at $0.3-\mathrm{nm}$ resolution. Eur. J. Biochem. 1989, 178, 693-703.

(46) Savvides, S. N.; Karplus, P. A. Kinetics and crystallographic analysis of human glutathione reductase in complex with a xanthene inhibitor. J. Biol. Chem. 1996, 271, 8101-8107.

(47) Schönleben-Janas, A.; Kirsch, P.; Mittl, P. R. E.; Schirmer, R. H.; Krauth-Siegel, R. L. Inhibition of human glutathione reductase by 10-arylisoalloxazines: crystallographic, kinetic and electrochemical studies. J. Med. Chem. 1996, 39, 1549-1554.

(48) Stourac, J.; Vavra, O.; Kokkonen, P.; Filipovic, J.; Pinto, G.; Brezovsky, J.; Damborsky, J.; Bednar, D. Caver Web 1.0: identification of tunnels and channels in proteins and analysis of ligand transport. Nucleic Acids Res. 2019, 47, W414-W422.

(49) Morris, G. M.; Huey, R.; Lindstrom, W.; Sanner, M. F.; Belew, R. K.; Goodsell, D. S.; Olson, A. J. AutoDock4 and AutoDockTools4: Automated docking with selective receptor flexibility. J. Comput. Chem. 2009, 30, 2785-2791.

(50) House, H. O.; Jones, V. K.; Frank, G. A. The chemistry of carbanions. VI. Stereochemistry of the Wittig reaction with stabilized ylids. J. Org. Chem. 1964, 29, 3327-3333.

(51) Koch, F.; Stolte, M.; Zitzler-Kunkel, A.; Bialas, D.; Steinbacher, A.; Brixner, T.; Würthner, F. Unraveling the structure and exciton coupling for multichromophoric merocyanine dye molecules. Phys. Chem. Chem. Phys. 2017, 19, 6368-6378.

(52) Hamilton, C. J.; Saravanamuthu, A.; Eggleston, I. M.; Fairlamb, A. H. Ellman's-reagent-mediated regeneration of trypanothione in situ: substrate-economical microplate and time-dependent inhibition assays for trypanothione reductase. Biochem. J. 2003, 369, 529-537.

(53) Baici, A. Kinetics of Enzyme-Modifier Interactions. Selected Topics in the Theory and Diagnosis of Inhibition and Activation Mechanisms; 1st ed.; Springer: Vienna, Austria, 2015.

(54) Aldrich, C.; Bertozzi, C.; Georg, G. I.; Kiessling, L.; Lindsley, C.; Liotta, D.; Merz, K. M., Jr.; Schepartz, A.; Wang, S. The ecstasy and agony of assay interference compounds. J. Med. Chem. 2017, 60, $2165-2168$.

(55) Klett, J.; Núñez-Salgado, A.; Dos Santos, H. G.; CortésCabrera, A.; Perona, A.; Gil-Redondo, R.; Abia, D.; Gago, F.; Morreale, A. MM-ISMSA: an ultrafast and accurate scoring function for protein-protein docking. J. Chem. Theory Comput. 2012, 8, 33953408.

(56) Schrodinger, L. L. C. The PyMOL Molecular Graphics System, Version 1.8, 2015. 